Федеральное государственное бюджетное образовательное учреждение высшего образования «Пермский государственный медицинский университет имени академика Е.А. Вагнера»

Министерства здравоохранения Российской Федерации Федеральное государственное бюджетное образовательное учреждение высшего образования «Уральский государственный медицинский университет» Министерства здравоохранения Российской Федерации

\title{
МИКРО- И МАКРОЭЛЕМЕНТЫ И ЖЕНСКОЕ ЗДОРОВЬЕ
}

Учебное пособие

Пермь 2021 


\section{Авторы:}

Олина Анна Александровна - первый заместитель директора ФГБНУ «Научно-исследовательский институт акушерства, гинекологии и репродуктологии имени Д.О. Отта», профессор кафедры акушерства и гинекологии ФГБОУ ВО «Северо-Западный государственный медицинский университет имени И.И. Мечникова» Минздрава России, профессор кафедры акушерства и гинекологии № 1 ФГБОУ ВО «Пермский государственный медицинский университет им. академика Е.А. Вагнера» Минздрава России, д-р мед. наук, профессор.

Садыкова Гульнара Камильевна - доцент кафедры акушерства и гинекологии № 1 ФГБОУ ВО «Пермский государственный медицинский университет им. академика Е.А. Вагнера» Минздрава России, канд. мед. наук.

Прохорова Ольга Валентиновна - доцент кафедры акушерства, гинекологии и трансфузиологии ФГБОУ ВО «Уральский государственный медицинский университет» Минздрава России, канд. мед. наук.

Метелева Татьяна Александровна - ассистент кафедры акушерства и гинекологии №1 ФГБОУ ВО «Пермский государственный медицинский университет им. академика Е.А. Вагнера» Минздрава России.

Ширинкина Елена Викторовна - доцент кафедры акушерства и гинекологии № 1 ФГБОУ ВО «Пермский государственный медицинский университет им. академика Е.А. Вагнера» Минздрава России, канд. мед. наук.

УДК 613.27

ББК 51.230

M597

\section{Рецензенты:}

заведующий кафедрой акушерства и гинекологии №3

ФГБОУ ВО «Ростовский государственный медицинский университет» Минздрава РФ, доктор медицинских наук, доцент Елизавета Юрьевна Лебеденко; профессор кафедры акушерства и гинекологии с курсом перинатологии

(Медицинский институт) ФГАОУ ВО «Российский университет дружбы народов», доктор медицинских наук, доцент Алина Викторовна Соловьева

M597 Микро- и макроэлементы и женское здоровье : учеб. пособие / А.А. Олина, Г.К. Садыкова, О.В. Прохорова, Т.А. Метелева, Е.В. Ширинкина. - Пермь, 2021. - 146 с.

$$
\text { ISBN 978-5-398-02576-7 }
$$

В учебном пособии рассматриваются физиологические функции микрои макроэлементов, а также влияние дефицитарных состояний на женскую репродуктивную систему и перинатальные исходы.

Издание предназначено для студентов IV и V курсов лечебного, педиатрического и медико-профилактического факультетов по дисциплине «Акушерство и гинекология».

Печатается по решению ученого совета ФГБОУ ВО «Пермский государственный медицинский университет им. академика Е.А. Вагнера» Минздрава России от 23.06.2021 г., протокол № 8 


\section{СОДЕРЖАНИЕ}

содержание............................................................................. 3

Список сокращений ....................................................................... 4

Введение ................................................................................. 5

Кальций ................................................................................... 6

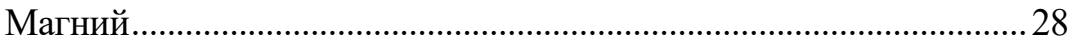

Железо ..................................................................................... 49

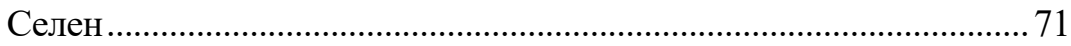

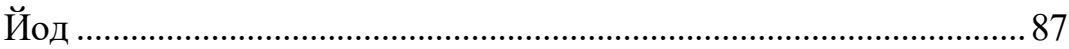

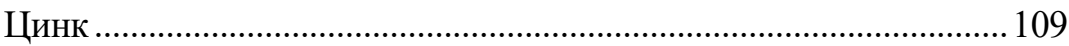

Тестовые задания ................................................................. 128

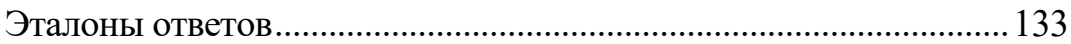

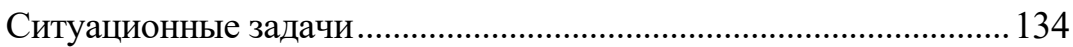

Эталоны ответов на ситуационные задачи ................................. 137

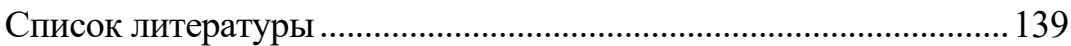




\section{СПИСОК СОКРАЩЕНИЙ}

АД - артериальное давление

АФК - активные формы кислорода

АТФ - аденозинтрифосфат

ВОЗ - Всемирная организация здравоохранения

ЖДА - железодефицитная анемия

ЖКТ - желудочно-кишечный тракт

ЗРП - задержка роста плода

ИПФР-1 - инсулиноподобный фактор роста-1

ЙД - йододефицит

ЙД3 - йододефицитные заболевания

ИБС - ишемическая болезнь сердца

МГТ - менопаузальная гормональная терапия

НЖК - незаменимые жирные кислоты

НПВС - нестероидные противовоспалительные средства

ПНЖК - полиненасыщенные жирные кислоты

ПР - преждевременные роды

ПТГ - паратиреоидный гормон

ПЭ - преэклампсия

РААС - ренин-ангиотензин-альдостероновая система

СП - селенопротеин

СС3 - сердечно-сосудистые заболевания

СТГ - соматотропный гормон

ТГ - тиреоидные гормоны

ЦНС - центральная нервная система

ХГЧ - хорионический гонадотропин человека

ЩЖ - щитовидная железа

ЭКО - экстракорпоральное оплодотворение

FDA - Foodand Drug Administration (Управление по санитарному надзору за качеством пищевых продуктов и медикаментов, США)

FIGO - International Federation of Gynecology and Obstetrics 


\section{ВВЕДЕНИЕ}

Адекватное сбалансированное питание женщины является одним из важнейших аспектов на этапах прегравидарной подготовки, в период беременности и лактации. Значительное влияние на состояние и становление здоровья матери и плода оказывают питательные вещества, поступающие в организм в указанные периоды. Так, в период беременности и лактации потребность в витаминах и минералах может увеличиваться на 20-50 \%. В зависимости от диеты, образа жизни, возраста, физической активности, веса тела до беременности, отягощенности клинического анамнеза, региона проживания женщины по разным причинам могут нуждаться в дополнительной дотации микро- и макроэлементов. С дефицитом таких элементов, как кальций, селен, желе30, магний, йод, ассоциируется развитие осложнений беременности и патологические состояния новорожденных. В этом случае задачей консультирующего врача - акушера-гинеколога становится грамотный дифференцированный подход к нутритивной поддержке на этапах подготовки и ведения беременности, а также во время лактации. В данном пособии рассматриваются физиологические функции микро- и макроэлементов, а также влияние дефицитарных состояний на женскую репродуктивную систему и перинатальные исходы. 


\section{КАЛЬЦИЙ}

Кальций (лат. - Calcium, Сa) является одним из самых распространенных минералов в организме человека, большая часть которого находится в костях скелета и зубах, обеспечивая жесткость и структурную целостность этих тканей. Одновременно с этим данный минерал служит резервуаром для поддержания концентрации кальция в сыворотке крови. В организме взрослого человека содержится около 1200 г Са, что составляет около 1-2 \% массы его тела. Хотя большая часть Са в организме изолирована в скелете, свободный гидратированный катион в растворе является ключевым физиологическим посредником во множестве метаболических и регуляторных процессов и играет значимую роль в обеспечении сокращения сосудов и вазодилатации, сокращении мышц, процессах нервной передачи и секреции гормонов.

Хотя с соединениями Са человечество сталкивалось практически на протяжении всей своей истории, как металл Са был открыт в начале XIX в. Мрамор, гипс, мел, известняк - все это минералы Са. При обжиге известняка, карбоната $\left(\mathrm{CaCO}_{3}\right)$ получали негашеную известь, представлявшую собой оксид кальция $(\mathrm{CaO})$. Однако в прошлом полагали, что известь является простым веществом. Наряду со многими другими минералами ее относили к «землям». И лишь в конце XVIII в., когда химия зарождалась как наука, предположили, что известь является комбинацией веществ. В 1809 г. английский химик Дэви получил чистый металл путем электролиза смеси оксида ртути и гидроксида кальция $\left(\mathrm{Ca}(\mathrm{OH})_{2}\right)$, более известного как гашеная известь. Новый металл назвали кальцием, от лат. calx, известь. Примечательно, что в России поначалу его называли известковием или известковостью.

В периодической системе элементов Менделеева Са значится под № 20. Он расположен во II группе 4-го периода. Его атомная масса равна 40. Хотя встречаются и другие изотопы Са. 
Bсе металлы II группы относятся к щелочноземельным металлам. На внешней орбите атомов щелочноземельных металлов вращаются два электрона, которые они сравнительно легко отдают атомам других веществ при взаимодействии с ними. Поэтому эти металлы двухвалентны. Как следует из названия, щелочноземельные металлы способны образовывать щелочи или гидроксиды, основания. Правда, эти основания не столь агрессивны в химическом плане, как основания щелочных металлов.

Са представляет собой серебристо-белый твердый металл. Он довольно легкий. Его плотность составляет 1,55 г/ $\mathrm{cm}^{3}$. Температура плавления $851^{\circ} \mathrm{C}$, температура кипения $1482^{\circ} \mathrm{C}$. Са химически активен, и потому в чистом виде в природе не встречается. Даже в лабораторных условиях для того, чтобы сохранить его металлические образцы, их хранят в керосине или в парафине. Иначе металл разрушится под действием атмосферного кислорода и углекислоты. Зато природа богата соединениями Са. Известно около 385 кальцийсодержащих минералов. Среди них - полевой шпат, ангидрит, флюорит, арагонит и многие другие. По разнообразию минералов Са занимает 4-е место среди других химических элементов. А по распространенности в земной коре 5-е место среди всех химических элементов и 3-е место среди металлов. Только алюминия и железа больше, чем Са. На долю Са приходится 2,96 \% массы земной коры. Одни кальцийсодержащие минералы находятся в твердом состоянии в составе горных и осадочных пород. Другие растворены в воде озер, морей и океанов. Растворенный в воде Са проникает в ткани растений, а в составе растений - в организм животных. В свою очередь растения и животные являются «поставщиками» его для человека.

\section{Основы метаболизма}

Более $99 \%$ Са в организме находится в зубах и костях, где он присутствует в виде фосфата кальция и карбоната. Оставшийся $1 \%$ обнаруживается в крови, внеклеточной жидкости, мышцах и других тканях. 
Баланс Са строго регулируется согласованным действием его абсорбции в кишечнике, реабсорбции в почках и обмена в костной ткани, которые участвуют в поддержании концентрации ионизированного Са в плазме в строгом диапазоне. Столь жесткое регулирование концентрации плазматического Са достигается за счет сложных физиологических систем, включающих взаимодействие кальциотропных гормонов, таких как паратиреоидный гормон (ПТГ), витамин $\mathrm{D}_{3}$ (или 1,25 дигидроксихолекальциферол $\left(1,25(\mathrm{OH})_{2} \mathrm{D}_{3}\right)$ и кальцитонин, со специфическими тканями-мишенями (почки, кости и кишечник), которые влияют на увеличение или уменьшение поступления Са во внеклеточное пространство. Секреция этих гормонов полностью или частично регулируется концентрацией в плазме ионизированного Са, образуя таким образом систему отрицательной обратной связи.

ПТГ представляет собой полипептид, секретируемый паращитовидными железами в ответ на снижение концентрации ионизированного Са в плазме. Эффекты ПТГ в виде увеличения концентрации Са в плазме могут реализоваться тремя способами: 1) стимуляция резорбции костей; 2) усиление всасывания Са и фосфата в кишечнике, способствуя образованию в почках витамина $\mathrm{D}_{3} ; 3$ ) увеличение активного всасывания Са почками. Эти эффекты сопровождаются небольшими изменениями концентрации Са в сыворотке, которые снижают секрецию ПТГ.

Витамин $\mathrm{D}_{3}$ представляет собой жирорастворимый стероид, который присутствует в рационе питания, а также может синтезироваться в коже из 7-дегидрохолестрола в присутствии ультрафиолета. Наиболее важным эндокринным эффектом витамина $\mathrm{D}_{3}$ в почках является жесткий контроль собственного гомеостаза путем одновременного подавления фермента $\alpha$-гидроксилазы и стимуляции 24-гидроксилазы. Неповрежденная и функционирующая в физиологическом режиме система рецепторов к витамину $\mathrm{D}_{3}$ имеет решающее значение как для базального, так и для 
индуцированного ПТГ остеокластогенеза. Зрелые остеокласты высвобождают Са и фосфор из костей, поддерживая соответствующий уровень двух минералов в плазме.

Общий сывороточный Са состоит из ионизированных, связанных с белками (альбумином и глобулинами) и комплексных фракций, связанных с молекулами цитрата и фосфата (примерно 48; 46 и 7 \% соответственно). Нормальный уровень общего Са в сыворотке составляет примерно 8,9-10,1 мг/дл (примерно 2,2-2,5 ммоль/л).

Здоровый взрослый человек нуждается в ежедневном поступлении в организм около 800-1000 мг Са. Это количество будет варьироваться в зависимости от количества потребляемых молочных продуктов. Примерно 400 мг из обычных 1000 мг Са, потребляемого с пищей, всасывается в кишечнике, а потеря Са с кишечными секретами составляет примерно 200 мг/сут. Следовательно, чистое всасывание Са, происходящее почти исключительно в двенадцатиперстной, тощей и подвздошной кишке, составляет примерно 200 мг/сут (20\%).

Некоторое количество абсорбированного Са выводится из организма с мочой, калом и потом. На эти процессы влияют такие факторы, как:

- потребление натрия и белка: повышенное поступление натрия в организм человека увеличивает выведение Са с мочой. Существовало мнение о том, что избыточное поступление белка также увеличивает выведение Са и, таким образом, отрицательно влияет на кальциевый статус. Однако более поздние исследования показывают, что высокое потребление белка также увеличивает всасывание Са в кишечнике, эффективно компенсируя его влияние на выведение Са, поэтому его баланс в организме остается неизменным;

- потребление кофеина: это вещество, содержащееся в кофе и чае, может незначительно увеличить выведение Са и снизить его абсорбцию. Одна чашка сваренного кофе, например, вызывает потерю всего 2-3 мг Са; 
- прием алкоголя: может влиять на статус Са, уменьшая его всасывание и ингибируя ферменты в печени, которые участвуют в преобразовании витамина D в его активную форму. Однако количество алкоголя, необходимое для воздействия на кальциевый статус, и то, какое именно влияние оказывает умеренное употребление алкоголя на остеосинтез, до сих пор неизвестно;

- потребление фосфора: влияние этого минерала на выведение Са минимально. Несколько наблюдательных исследований показали, что потребление газированных безалкогольных напитков с высоким уровнем фосфатов связано со снижением костной массы и повышенным риском переломов;

- потребление фруктов и овощей: применение диет с высоким содержанием белка и злаков активирует выведение Са из организма. Избыточное потребление фруктов и овощей сдвигает кислотно-щелочной баланс организма в сторону щелочного за счет синтеза бикарбоната, который снижает выведение Са. Однако неясно, влияет ли потребление большего количества фруктов и овощей на минеральную плотность костей. Эти продукты, помимо уменьшения экскреции Са, могут снизить всасывание Са из кишечника и, следовательно, не имеют исключительно однонаправленного влияния на его баланс.

Факторы, влияющие на почечную регуляцию кальциевого обмена, представлены в табл. 1.

Таблица 1

Факторы, влияющие на почечную регуляцию кальция

\begin{tabular}{|c|c|}
\hline Увеличивают абсорбцию кальция & Уменьшают всасывание кальция \\
\hline Гиперпаратиреоз & Гипопаратиреоз \\
\hline Кальцитриол & Низкий уровень кальцитриола \\
\hline Гипокальциемия & Гиперкальциемия \\
\hline Сокращение объемавнеклеточной жидкости & Расширение внеклеточной жидкости \\
\hline Метаболический алкалоз & Метаболический ацидоз \\
\hline Тиазидные диуретики & Петлевые диуретики \\
\hline
\end{tabular}




\section{Причины изменения баланса кальция}

Основные причины гипокальциемии:

- недостаток ПТГ (наследственный или приобретенный гипопаратиреоз);

- недостаток витамина D (диетический дефицит, синдром мальабсорбции, неадекватный солнечный свет и нарушение метаболизма, связанное с заболеваниями печени и почек);

- повышенное комплексообразование Са (рабдомиолиз, острый панкреатит, синдром лизиса опухоли).

Основные причины гиперкальциемии:

- избыточная продукция ПТГ (первичный гиперпаратиреоз);

- избыток $1,25(\mathrm{OH})_{2} \mathrm{D}$ (интоксикация витамином D, саркоидоз);

- повышенная резорбция кости (метастатические остеолитические опухоли, гуморальная гиперкальциемия, иммобилизация, болезнь Педжета);

- повышенное всасывание Са в кишечнике;

- снижение почечной экскреции Са;

- нарушение формирования костей (адинамическая болезнь костей).

\section{Физиологические функции}

Кальций относится к макроэлементам - его очень много в нашем организме. На его долю приходится около 2 \% массы тела. Таким образом, в организме человека со средней массой 70 кг содержится около 1500 мг этого макроэлемента. Правда, у лиц с избыточной массой тела, страдающих ожирением, этот процент меньше за счет высокого содержания жировой ткани.

Общеизвестна роль его в формировании опорно-двигательного аппарата. Именно здесь сосредоточено 99 \% его запасов. Благодаря ему кости становятся прочными, повышается их устойчивость к внешним травмирующим факторам, снижается 
опасность переломов. Помимо костей он обеспечивает прочность связок, мышечных сухожилий, суставных капсул. Довольно много этого минерала сосредоточено в эмали и дентине зубов, а также в веществе ногтей.

Всего $1 \%$ находится в плазме крови и в межклеточных тканях, но именно от этого количества в немалой степени зависит нормальное протекание физиологических процессов в нашем организме. Около 2000 ферментов контролируются им. Свое действие этот макроэлемент реализует на всех уровнях: субклеточном, клеточном, тканевом и системном.

Вместе с другими макроэлементами, натрием, калием, магнием, хлором и фосфором, кальций формирует водно-электролитный баланс, регулирует кислотно-щелочное равновесие. Он участвует в клеточном обмене веществ (метаболизме). Он укрепляет мембраны клеток и регулирует их проницаемость для других биологически активных веществ (БАВ), в том числе и гормонов.

Под действием Са проницаемость биологических мембран снижается. Это имеет большое значение при воспалительных и аллергических процессах. Эти патологические процессы имеют много общего между собой. В их основе лежит высвобождение гистамина тканевыми тучными клетками. В итоге развиваются типичные симптомы отека, зуда, бронхоспазма, а также появления воспалительного выпота, экссудата. Он укрепляет мембрану тучных клеток и предотвращает выход гистамина. Также он препятствует высвобождению других БАВ, медиаторов воспаления и аллергии, улучшает барьерные свойства тканей и устраняет отеки и экссудацию.

Сходным образом он влияет на сосудистую стенку. Снижает ее проницаемость для плазмы и для форменных элементов и предупреждает появление отеков и кровоизлияний. Кроме того, Са повышает свертываемость крови. В системе гемостаза ионы Са обозначаются как плазменный фактор IV. Эти ионы активируют другие факторы свертывания. В частности, благодаря кальцию протромбин трансформируется в тромбин. Он оказывает не 
только гемостатическое, но и антиатеросклеротическое действие. Са угнетает синтез низкоплотного холестерина и препятствует отложению атеросклеротических бляшек на сосудистых стенках. Однако этим влияние его на состояние кровеносных сосудов не исчерпывается. Ведь именно он регулирует тонус гладкой мускулатуры сосудов. Благодаря ему происходит расслабление и спазм гладких мышц сосудистой стенки, расширение и сужение сосудов, повышение и снижение артериального давления (АД). Механизм регуляции системного АД кальцием довольно сложен. Суть заключается в том, что катионы Са неравномерно содержатся в клетках и в межклеточном пространстве. Снаружи клетки кальция примерно в 25 раз больше, чем внутри ее. Таким образом, минерал является внеклеточным ионом. Разница или градиент концентрации поддерживается его ферментом - зависимой АТФ-азой. Этот фермент постоянно выталкивает его наружу, и тем самым поддерживает градиент. Для того чтобы попасть внутрь клетки, кальцию нужен белок-переносчик, именуемый кальциевым каналом. Ион Са соединяется с кальциевым каналом, и в таком виде транспортируется внутрь клетки гладкого мышечного волокна.

В каждом волокне присутствуют сократительные белки, актин и миозин, которые имеют вид тончайших нитей, микрофибрилл. Актиновые фибриллы более тонкие и длинные в сравнении с миозиновыми. Под действием ионов Са актиновые и миозиновые фибриллы заходят друг за друга. Это ведет к утолщению и укорочению мышечного волокна и, соответственно, всей мышцы. Таким образом, под действием кальция волокна гладкой мышечной оболочки сокращаются, сосуд спазмируется, и АД поддерживается на должном уровне. Благодаря этому осуществляется эффективное кровоснабжение органов и тканей.

Кальциевые каналы представлены несколькими видами. Они присутствуют не только в гладкой мускулатуре сосудов, но и в других видах мышечной ткани: в скелетных мышцах, в миокарде, в гладкой мускулатуре ЖКТ (желудочно-кишечного тракта). И 
везде кальций играет ключевую роль в поддержании тонуса. Под его действием возрастает сила сердечных сокращений (положительный инотропный эффект). Это тоже способствует эффективному кровоснабжению тканей и их насыщению кислородом.

Са регулирует перистальтику гладкой мускулатуры ЖКТ, и способствует плавному перемещению пищевого комка. Кроме того, он стимулирует выработку пищеварительных ферментов в составе кишечных соков и сока поджелудочной железы.

Этот макроэлемент формирует тонус сфинктеров желчевыводящих путей, мочевого пузыря.

Са влияет не только на гладкую, но и на скелетную мускулатуру. И это влияние многообразно. Кальций запускает взаимодействие сократительных белков.

Кроме того, ионы кальция наряду с другими факторами обеспечивают нервно-мышечную передачу - распространение двигательного импульса с нервного волокна на скелетную мышцу. Он улучшает кровоснабжение в мышечной ткани и стимулирует синтез мышечных белков. В результате увеличивается мышечная сила и выносливость.

Повышению мышечной выносливости способствует и тот факт, что он утилизирует молочную кислоту, образующуюся при мышечной работе. Ионы Са способствуют алкалозу тканевых сред. Мышечная работа, воспалительные процессы, многие обменные нарушения протекают с закислением, ацидозом. При ацидозе накапливается большое количество токсичных недоокисленных продуктов. И благодаря ему происходит утилизация, обезвреживание этих продуктов и устранение ацидоза.

Кальций участвует в синтезе многих нейромедиаторов. Благодаря ионам Са происходит распространение импульсов по чувствительным и двигательным нервным волокнам, иннервирующим не только скелетные мышцы, но и другие анатомические структуры. Наравне с другими электролитами Са обеспечивает генерацию и проведение импульсов по проводящей системе сердца. Миокард сокращается с правильным ритмом и частотой. 
Этот макроэлемент стимулирует высшую нервную деятельность, улучшает мышление и память. Это играет большую роль в детском возрасте, в период становления эмоциональноволевой сферы, и у пожилых людей, у которых ментальные функции угасают, и очень важно их сохранить. Он регулирует углеводный обмен. Он участвует в выработке инсулина и тем самым обеспечивает транспорт глюкозы в клетку, препятствуя развитию сахарного диабета. Расщепление и утилизация жиров тоже происходит не без его участия. И это также снижает риск сахарного диабета. Ведь ожирение - одна из основных причин этого эндокринного заболевания. Кальций принимает непосредственное участие в функционировании клеточного и гуморального иммунитета. Он повышает устойчивость к инфекционным заболеваниям, а после этих заболеваний, травм и оперативных вмешательств выздоровление наступает быстрее. Этому же способствует и то, что ионы кальция защищают от повреждения нуклеиновые кислоты, ДНК и РНК. Благодаря этому осуществляется правильное деление клеток. Быстрее восстанавливаются поврежденные ткани. Предотвращается появление бурно делящихся клеток с атипичными свойствами, которые дают начало злокачественным опухолям.

\section{Содержание в продуктах, суточные нормативы потребления кальция}

Молоко и молочнокислые продукты, такие как йогурт и сыр, являются богатыми природными источниками Са и лежат в основе богатого Са рациона. Немолочные источники данного микроэлемента включают овощи, такие как китайская и белокочанная капуста, а также брокколи. Большинство злаков не содержат большого количества $\mathrm{Ca}$, если они дополнительно не обогащены; однако они вносят дополнительное количество Са в рацион в связи с частым употреблением в пищу. Продукты, 
обогащенные $\mathrm{Ca}$, включают множество фруктовых соков и напитков, тофу и злаки. Избранные пищевые источники Са представлены в табл. 2.

Помимо количества Са в рационе, абсорбция Са из пищевых продуктов также является критическим фактором, определяющим доступность Са для развития и поддержания костей. Таким образом, существует потребность в идентификации пищевых компонентов и / или функциональных пищевых ингредиентов, которые могут положительно влиять на абсорбцию Са, чтобы гарантировать, что биодоступность Са из пищевых продуктов может быть оптимизирована.

К сожалению, существуют большие расхождения в оценках суточной потребности в Са, сделанных различными экспертными организациями. Наряду с этим текущие национальные рекомендации по питанию и по лечению заболеваний костей, включающие в схемы терапии препараты Са, значительно различаются между странами и профессиональными организациями.

Рекомендации по диетическому поступлению Са были обновлены Институтом медицины (США) в 2011 г. Согласно современным исследованиям, крайне перспективным считается изучение взаимодействия Са с другими питательными веществами, например белком, натрием и фосфором. В настоящее время изучаются меры по улучшению использования организмом человека ионов Са, например путем дополнительного применения пребиотиков. В целом следует отметить, что больше научного внимания зарубежными коллегами уделяется моделям питания населения разных стран и матричным эффектам основных источников пищи, таких как молочные продукты, для получения Сa.

Советом по пищевым продуктам и питанию Института медицины национальных академий (США) разработаны рекомендации, представляющие средние диетические нормы потребления $\mathrm{Ca}$, необходимого для здоровья костей и для поддержания адекватного его уровня в сыворотке крови (табл. 3). 
Т а блица 2

\section{Содержания кальция в продуктах питания}

\begin{tabular}{|l|c|}
\hline \multicolumn{1}{|c|}{ Продукт, вес одной порции } & Содержание, мг/100 г \\
\hline Пармезан & 1300 \\
\hline Сыр российский & 1000 \\
\hline Соевые бобы & 240 \\
\hline Фасоль & 194 \\
\hline Бобы & 100 \\
\hline Кунжут & 780 \\
\hline Миндаль & 250 \\
\hline Семена подсолнуха & 100 \\
\hline Грецкие орехи & 90 \\
\hline Арахис & 60 \\
\hline Сардины, консервированные в масле & 380 \\
\hline Молоко обезжиренное & 125 \\
\hline Соевое молоко & 80 \\
\hline Молоко коровье с пониженным содержанием & 120 \\
\hline жира (2,5-3,5 \% молочного жира) & 10 \\
\hline Лосось & 120 \\
\hline Творог & 370 \\
\hline Базилик & 245 \\
\hline Петрушка (зелень) & 212 \\
\hline Капуста савойская & 210 \\
\hline Капуста белокочанная & 180 \\
\hline Кресс-салат & 240 \\
\hline Шоколад молочный & 60 \\
\hline Шоколад темный & 140 \\
\hline Мороженое молочное & 80 \\
\hline Курага & 54 \\
\hline Инжир вяленый & 50 \\
\hline Изюм & 55 \\
\hline Зерновой хлеб & 23 \\
\hline Хлеб из отрубей & 52 \\
\hline Белый хлеб & 50 \\
\hline Овсяные хлопья & 30 \\
\hline Хлеб ржаной & \\
\hline
\end{tabular}


Рекомендуемые суточные нормы потребления кальция (мг)

\begin{tabular}{|l|c|c|c|c|}
\hline \multicolumn{1}{|c|}{ Возраст } & Мужчины & Женщины & $\begin{array}{c}\text { Беременные } \\
\text { женщины }\end{array}$ & $\begin{array}{c}\text { Кормящие } \\
\text { женщины }\end{array}$ \\
\hline $0-6$ месяцев & 200 & 200 & - & - \\
\hline $7-12$ месяцев & 260 & 260 & - & - \\
\hline $1-3$ года & 700 & 700 & - & - \\
\hline $4-8$ лет & 1000 & 1000 & - & - \\
\hline 9-13 лет & 1300 & 1300 & - & 1300 \\
\hline $14-18$ лет & 1300 & 1300 & 1300 & 1000 \\
\hline $19-50$ лет & 1000 & 1000 & 1000 & - \\
\hline $51-70$ лет & 1000 & 1200 & - & - \\
\hline Старше 71 года & 1200 & 1200 & - & - \\
\hline
\end{tabular}

На усвоение $\mathrm{Ca}$, поступающего ежедневно в организм человека, дополнительно влияет целый ряд факторов, таких как:

- потребляемое количество Са: эффективность абсорбции снижается по мере увеличения потребления $\mathrm{Ca}$;

- возраст человека: чистое всасывание Са достигает 60 \% у младенцев и детей раннего возраста, которым необходимо значительное количество минерала для построения костей. В дальнейшем его абсорбция снижается до 15-20 \% в зрелом возрасте (при этом увеличивается во время беременности) и продолжает снижаться с течением лет. Именно по этой причине большинство руководств содержит рекомендации по более высокому потреблению Са для женщин старше 50 лет, а также для мужчин и женщин старше 70 лет;

- потребление витамина $\mathrm{D}_{3}$ : холекальциферол синтезируется в коже под действием ультрафиолетовых лучей и обеспечивает всасывание Са и фосфора из пищи в тонкой кишке;

- другие компоненты пищи: фитиновая кислота и щавелевая кислота связываются с Са и могут препятствовать его усвоению. Продукты с высоким уровнем щавелевой кислоты включают шпинат, зелень капусты, сладкий картофель, ревень и бобы. К продуктам с высоким содержанием фитиновой кислоты 
относятся цельнозерновые продукты, содержащие клетчатку, а также пшеничные отруби, бобы, семена, орехи и соя. Степень, в которой эти соединения влияют на абсорбцию Са, варьируется. Исследования показывают, например, что одновременное употребление шпината и молока снижает абсорбцию Са с молоком. Напротив, продукты из пшеницы (за исключением пшеничных отрубей), по-видимому, не снижают абсорбцию Са. Для людей, которые ежедневно употребляют разнообразную пищу, эти взаимодействия, вероятно, имеют незначительные последствия или вообще не имеют их.

\section{Эпидемиология}

Потребление Са с пищей оказывает важное влияние на метаболизм и здоровье костей. Следует помнить, что, хотя уровень Са в сыворотке может поддерживаться в нормальном диапазоне за счет резорбции костей, потребление пищи является единственным источником, с помощью которого организм может пополнить запасы Са в костях. Хронический дефицит Са, возникающий из-за недостаточного потребления или плохой абсорбции в кишечнике, является одной из нескольких важных причин снижения костной массы и остеопороза. Поэтому жизненно важно, чтобы достаточное количество Са потреблялось с пищей на всех этапах жизни: в раннем возрасте, чтобы можно было достичь генетически запрограммированной максимальной костной массы, и в более зрелом возрасте, чтобы можно было поддерживать скелетную массу и возрастные потери костной массы были сведены к минимуму.

Группы риска пациентов по недостаточности Са:

- женщины в постменопаузе. Снижение выработки эстрогенов увеличивает резорбцию костей и снижает всасывание Са. Ежегодное снижение костной массы на 3-5\% в год часто происходит в первые годы менопаузы, но после 65 лет снижение обычно составляет менее $1 \%$ в год. Повышенное потребление 
Са во время менопаузы не полностью компенсирует потерю костной массы. Менопаузальная гормональная терапия (МГТ) препаратами эстрогенов и прогестерона помогает повысить уровень Са и предотвратить остеопороз и переломы костей. Поступление экзогенных эстрогенов в составе МГТ восстанавливает ремоделирование костей в постменопаузе до тех же уровней, что и в пременопаузе, что приводит к более низким показателям потери костной массы, возможно, частично за счет увеличения всасывания Са в кишечнике;

- женщины с аменореей (гипофункция яичников, анорексия, профессиональные занятия спортом). Происходящее по разным причинам снижение уровней циркулирующих эстрогенов ведет к снижению абсорбции Са и более высокой скорости выведения его с мочой, а также более низкому темпу процессов остеосинтеза, чем у здоровых женщин;

- женщиины с непереносимостью лактозы или аллергией на коровье молоко. Вздутие живота, метеоризм и диарея проявляются у таких пациенток в случаях наличия у них недостаточности синтезируемого в тонкой кишке фермента лактазы. Ограничение потребления молочных продуктов, содержащих природный молочный сахар - лактозу - этими пациентками ведет к формированию у них риска недостаточности Са. Исследования показывают, что большинство людей с непереносимостью лактозы могут потреблять до 12 г лактозы (например один стакан молока) с минимальными симптомами или без них, особенно при употреблении с другими продуктами. Другие варианты донации Са в данном случае включают употребление в пищу молочных продуктов с низким содержанием лактозы, в том числе выдержанных сыров (таких как чеддер и швейцарский), йогурта или молока с пониженным содержанием лактозы или без нее. Чтобы обеспечить адекватное потребление Са, люди с непереносимостью лактозы и аллергией на коровье молоко могут выбирать немолочные источники питательных веществ (например капуста, китайская капуста, брокколи, листовая капуста и обогащенные продукты) или принимать добавки с Сa; 
- вегетарианц̧ы. В данном случае в группе риска по кальциевому дефициту находятся веганы (люди, которые не едят продукты животного происхождения) и ововегетарианцы (пациенты, которые едят яйца, но не молочные продукты). К сожалению, непросто оценить влияние вегетарианской диеты на кальциевый статус из-за большого разнообразия методов питания, и поэтому способы и сроки восполнения недостатка поступления Са следует рассматривать в индивидуальном порядке.

\section{Симптомы дефицита и избытка}

Недостаточное поступление Са с пищей и добавками не вызывает явных симптомов в краткосрочной перспективе. Уровень Са в циркулирующей крови строго регулируется. Гипокальциемия возникает в основном из-за заболеваний внутренних органов или препаратов, применяемых для их лечения, включая почечную недостаточность, хирургическое удаление желудка и прием определенных лекарств (например диуретиков). Симптомы гипокальциемии включают онемение и покалывание в пальцах, мышечные спазмы, судороги, плохой аппетит и нарушение сердечного ритма.

В организме ребенка дефицит Са вызывает нарушение фосфорно-кальциевого обмена, проявляющееся в виде рахита. В более зрелом возрасте у пациентов хроническая нехватка $\mathrm{Ca}$ реализуется в виде уменьшения костной массы и остеопоротических переломов. Низкие концентрации Са в кишечнике, вызванные недостаточным потреблением с пищей, также связаны с повышенным риском образования камней в почках и рака толстой кишки. Вероятно, это связано с уменьшением связывания и повышенным всасыванием щавелевой кислоты (основного компонента камней в почках) и некоторых веществ, обладающих канцерогенными свойствами.

Допустимый верхний уровень дневного потребления Са с пищей установлен на уровне 2500-3000 мг для подростков и взрослых, 2500 мг для детей и 1000-1550 мг для младенцев. 
Известно, что потребление выше этих уровней увеличивает риск побочных эффектов, таких как гиперкальциемия и гиперкальциурия, образование камней в почках, кальцификация сосудов и мягких тканей, взаимодействие с абсорбцией цинка и железа и развитие запоров. Эти верхние уровни потребления примерно в 2-3 раза превышают суточную норму потребления.

Устойчивая гиперкальциемия натощак не возникает при добавлении Са в случае, если ось «кальций - паратироидный гормон - витамин $\mathrm{D}_{3}$ » не нарушена, а функция почек и кислотно-щелочной баланс в норме. Однако нарушения в этих системах в сочетании с пищевыми добавками с высоким содержанием Са или их потреблением могут привести к гиперкальциемии. Это также происходит, если высокое потребление Са происходит одновременно с повышением поступления щелочных компонентов пищи, изменяющей реабсорбцию Са в почках.

Избыточная минерализация костей, мягких тканей и кровеносных сосудов - сложный патофизиологический процесс, который также некоторое время назад рассматривался как некий побочный эффект чрезмерного поступления фосфата Са. Обеспокоенность по поводу приема добавок Са и кальцификации мягких тканей привела к разработке систематического обзора для информирования позиционного документа Национального фонда остеопороза и Американского общества профилактической кардиологии, в котором говорится об отсутствии доказательств такой связи.

\section{Акушерские и перинатальные результаты дефицитарных состояний}

Метаболизм Са во время беременности является сложным процессом, в котором кроме него участвуют фосфор, витамин D, ПТГ и кальцитонин. Всасывание Са увеличивается во время беременности, и, вероятно, также происходит увеличение его запасов в материнском скелете. Адекватные количества обес- 
печиваются действующей рекомендуемой диетической дозой 1000 мг ежедневно, которые легко можно получить с помощью натуральных продуктов, в частности молока. Общий уровень материнского сывороточного Са снижается во время беременности из-за физиологической гипоальбуминемии, однако уровень ионного Са остается постоянным, отчасти потому, что происходит увеличение выработки материнского ПТГ. Именно секреция ПТГ поддерживает уровень ионного Са в сыворотке крови в пределах характерно узких физиологических показателей в условиях увеличения объема внеклеточной жидкости, повышенной экскреции с мочой и передачи Са плоду. Кроме того, ПТГ способствует усиленному почечному синтезу витамина $\mathrm{D}_{3}$, который действует совместно с ПТГ, чтобы удовлетворить потребности гестации в Са.

Плацента играет основную роль в метаболизме Са у плода, транспортируя ионы Са от матери к плоду, против градиента концентрации. Высокие уровни ионного Са у плода вызывают подавление ПТГ и стимуляцию соматотропного гормона (СТГ) у плода, способствуя росту скелета плода. Первичная характеристика перинатального метаболизма Са - это активный плацентарный перенос ионов Са от матери к плоду, что делает плод относительно гиперкальциемическим. Поскольку ни один из кальцитропных гормонов не проникает через плаценту, гиперкальциемия, по-видимому, подавляет секрецию или активность ПТГ плодом и стимулирует высвобождение кальцитонина плода, создавая среду (с высоким содержанием $\mathrm{Ca}$, низким содержанием ПТГ, с высоким содержанием кальцитонина), благоприятную для роста скелета. С рождением ребенка использование трансплацентарного механизма метаболизма Са резко прекращается, и уровень Са в сыворотке снижается в течение 24-48 ч, после чего он стабилизируется.

Низкий уровень Са в пище повышает риск развития преэклампсии (ПЭ). ПЭ значительно более распространена в странах с низким уровнем дохода. Одно из возможных объяснений 
этого несоответствия - существующие значимые различия в стиле питания, особенно дефицит Са. Добавки Са во второй половине беременности уменьшают серьезные последствия ПЭ и рекомендованы Всемирной организацией здравоохранения (BO3) для женщин с низким потреблением Са с пищей. Текущие рекомендации касаются приема 1,5-2 г Са в день беременным женщинам с низким потреблением, основанные на рандомизированных контролируемых исследованиях приема $\geq 1$ г Са в день с 20 недель беременности. Добавление Са на прегравидарном этапе и на ранних сроках беременности может снизить риск развития ПЭ и потери беременности у женщин на любом сроке беременности.

\section{Способы лабораторной диагностики}

В настоящее время не существует общепринятого инструмента для оценки кальциевого статуса отдельных лиц или групп населения. Практически половина общего Са плазмы находится в связанном с альбумином плазмы состоянии. Оставшаяся часть этого вещества циркулирует в крови в физиологически активном ионизированном свободном состоянии. Помимо этого, определенное количество Са находится в крови, будучи связанным с анионами - лактатом, фосфатом, бикарбонатом, цитратом. В тех случаях, когда по каким-то причинам у пациента определяется гипоальбуминемия, уровень общего Са плазмы принято оценивать, делая поправку на связывание Са с белками. Для этого используют два формулы:

\footnotetext{
Общий Са плазмы (с поправкой) (ммоль/л) = = измеренный уровень Са плазмы (ммоль/л) + $+0,02 \cdot(40-$ измеренный уровень альбумина плазмы (г/л)).
} 
Общий Са плазмы (с поправкой) (мг/дл) = = измеренный уровень Са плазмы (мг/дл) +

$+0,8 \cdot(4-$ измеренный уровень альбумина плазмы (г/дл)).

Нормативы содержания Са в сыворотке крови представлены в табл. 4.

Т а бли ца 4

\section{Показатели общего сывороточного кальция в зависимости от возраста}

\begin{tabular}{|c|c|}
\hline Возраст & Референсные значения, ммоль/л \\
\hline Меньше 10 дней & $1,9-2,6$ \\
\hline 10 дней -2 года & $2,25-2,75$ \\
\hline $2-12$ лет & $2,2-2,7$ \\
\hline $12-18$ лет & $2,1-2,55$ \\
\hline $18-60$ лет & $2,15-2,5$ \\
\hline $60-90$ лет & $2,2-2,55$ \\
\hline$>90$ лет & $2,05-2,4$ \\
\hline
\end{tabular}

Традиционно для оценки состояния кальциевого обмена принято определять уровень общего Са в крови. Этот параметр является достаточно объективным показателем содержания свободного и связанного Са - на каждый из них приходится в среднем около 50 \% от показателя общего Са. Однако следует помнить, что, так как около половины Са в крови связано с белками, количество общего Са может изменяться, например при нарушениях белкового обмена.

\section{Варианты коррекции}

Кальциевые добавки широко используются врачами различных специальностей. Поскольку растворимость многих солей Са зависит от $\mathrm{pH}$, следует учитывать тип используемой соли, состояние пациента и время введения. Две основные формы Са в добавках представлены карбонатом и цитратом. Карбонат 
Са более доступен, он недорог и удобен. Из-за того, что его абсорбция зависит от состояния желудочной секреции, карбонат Са абсорбируется наиболее эффективно при приеме с пищей, тогда как цитрат Са всасывается одинаково хорошо при приеме с пищей или без нее. Цитрат Са также полезен для людей с ахлоргидрией, воспалительными заболеваниями кишечника или нарушениями всасывания. Другие формы Са в добавках или обогащенных продуктах включают глюконат, лактат и фосфат.

Добавки Са содержат различное количество элементарного Са. Например, карбонат кальция содержит 40 \% элементарного Са, цитрат кальция - 21 \%, глюконат кальция - 9\%, лактат Са $13 \%$. Данная информация традиционно размещается на упаковке препарата, поэтому ни врачам, ни пациенткам не нужно дополнительно рассчитывать количество микроэлемента, поступающего в организм с различными формами.

Процент абсорбированного Са зависит от общего количества элементарного Са, потребляемого за один раз, при этом по мере увеличения количества микроэлемента процент его поглощения уменьшается. Абсорбция Са наиболее высока при принимаемых дозах, составляющих $\leq 500$ мг. Таким образом, для оптимизации всасывания препаратов и повышения их биодоступности пациент, принимающий 1000 мг Са в день, может разделить дозу и принимать 500 мг в два разных приема в течение дня.

Некоторые люди, принимающие добавки Са, могут испытывать ряд побочных эффектов со стороны ЖКТ, включая вздутие живота, запоры или сочетание этих симптомов. Карбонат Са вызывает больше этих побочных эффектов, чем цитрат Са, поэтому при появлении сообщений об этих побочных эффектах следует рассмотреть вопрос о форме добавки Са. Другие стратегии для облегчения симптомов включают распределение дозы Са в течение дня и / или прием добавки во время еды.

Некоторые из различных диетических факторов, влияющих на всасывание Са в организме человека, оказывают негативное воздействие (например фитаты, оксалаты, фосфаты и 
клетчатка), снижая растворимость данного вещества. Напротив, молоко или молочные продукты улучшают всасывание Сa, потому что молоко содержит более растворимый кальцийбелковый комплекс, а молоко увеличивает кислотные выделения и время пребывания в желудке; оба эти условия увеличивают растворимость Са и, таким образом, способствуют усвоению.

Использование таких соединений, как карбонат и фосфат $\mathrm{Ca}$, обеспечивает поступление большего количества Са во время приема меньшего количества таблеток. Человеку потребуется 5,4 г лактата $\mathrm{Ca}$, чтобы получить такое же количество Са, что и в 2,5 г карбоната $\mathrm{Ca}$.

Федеральные клинические рекомендации «Нормальная беременность» (2019) предписывают назначение препаратов Са в дозе 1 г/сут внутрь пациенткам, относящимся к группе высокого риска преэклампсии при низком потреблении Са (менее 600 мг/сут). Данная рекомендация действует на протяжении всего срока беременности.

Медико-социальная значимость остеопороза и остеопоретических переломов костей ассоциирована с как с потерей минеральной плотности костей, так и с саркопенией. Поступление Са для пациенток старше 50 лет должно составлять 1200 мг в сутки, включая пищевые источники и добавки в виде препаратов. 


\section{МАГНИЙ}

Магний (лат. - Magnesium, Mg) содержится в организме в относительно большом количестве. Поэтому его относят к макроэлементам.

Человек еще в глубокой древности использовал в прикладных целях соединения магния - асбест, тальк, магнезит. Особенно большие залежи магнезита, сульфата магния (Magnesiisulfas, $\mathrm{MgSO}_{4}$ ), обнаружились близ города Магнезита, в Малой Азии. Отсюда произошло и название металла. Однако сам $\mathrm{Mg}$ долгое время оставался неизвестным, а его соединения из-за внешнего сходства часто путали с соединениями Са, в частности с известняком, гашеной и негашеной известью (с сульфатом, гидроксидом и оксидом Сa). Изучение его берет начало с XVII в. В 1618 г. в английском городе Эпсом открыли минеральный источник. Целебная вода в этом источнике была горьковатой на вкус и оказывала послабляющее действие. Позднее, в 1695 г., из этой воды выделили соль, которую назвали горькой, эпсомской или английской. Эта соль представляла собой порошкообразное вещество. Данное вещество назвали белой магнезией. Это был магния сульфат или сернокислая магнезия $\left(\mathrm{MgSO}_{4}\right)$. Примечательно, что поначалу магнезиями называли многие вещества, которые вместо Mg содержали соли железа, марганца, сурьмы, и других металлов. В 1818 г. он в чистом виде был выделен из гидроксида магния путем электролиза. В 1829 г. металлический $\mathrm{Mg}$ получили из хлорида магния при его взаимодействии с калием. Примечательно, что во многих европейских странах вновь открытый металл назвали магнезием. И лишь в России за ним закрепилось название магний.

$\mathrm{Mg}$ - металл серебристо-белого цвета. В периодической системе элементов Менделеева располагается во II группе 3-го периода под № 12 и относится к щелочноземельным металлам. 
Вокруг атомного ядра вращаются 12 электронов, два из которых - неспаренные. Соответственно, он является двухвалентным металлом, Mg (II). Атомная масса - 26. Но у металла есть множество других стабильных и нестабильных изотопов. Металл довольно легкий, легче алюминия. Его плотность составляет 1,738 г/см³. При этом он прочный, пластичный и легко поддается обработке. В связи с этим он нашел широкое применение в промышленности как в чистом виде, так и в сплавах с цинком, алюминием и другими металлами. Температура плавления $\mathrm{Mg}$ $650{ }^{\circ} \mathrm{C}$, температура кипения $1090^{\circ} \mathrm{C}$. Он с легкостью реагирует с кислородом и многими другими неметаллами. При взаимодействии с атмосферным кислородом на его поверхности образуется тончайшая оксидная пленка $\mathrm{MgO}$. Эта пленка плотно покрывает поверхность металла и предохраняет его от дальнейшего окисления. В земной коре на его долю приходится 1,87 \%, и по распространенности он занимает 8-е место среди других элементов. При этом из-за высокой способности реагировать с другими соединениями магний в чистом виде практически не встречается. Зато многие природные минералы его содержат. Довольно много магниевых солей находится в воде океанов, морей, некоторых озер и природных источников. Немаловажную роль он играет в живой природе. Растительный пигмент хлорофилл содержит $2,7 \% \mathrm{Mg}$. Этот минерал выполняет жизненно важные функции в организме человека и животных.

\section{Основы метаболизма}

Поступивший внутрь $\mathrm{Mg}$ в количестве 30-50 \% всасывается в тонком кишечнике. Остальная, невсосавшаяся часть макроэлемента выводится с калом. Хотя некоторое его количество может всасываться и в толстом кишечнике. Процесс всасывания зависит от нескольких факторов. Прежде всего, это виды соединений $\mathrm{Mg}$. Органический молочнокислый и лимоннокислый $\mathrm{Mg}$ 
(магния лактат и цитрат) всасывается намного лучше, чем неорганическиий сульфат. Однако это вовсе не означает, что принятый внутрь магния сульфат бесполезен. В просвете кишечника он не всасывается, но, будучи осмотически активным, притягивает воду. При этом объем кишечника увеличивается, усиливается кишечная перистальтика. Отсюда и послабляющий эффект английской соли. Весь этот процесс сопровождается отхождением желчи и панкреатического сока, что тоже позитивно сказывается на пищеварении. Кроме того, сернокислая магнезия эффективна при отравлении солями тяжелых металлов. В просвете кишечника она реагирует с этими солями с образованием нетоксичных сульфатов, которые выводятся наружу.

Усвояемость в немалой степени зависит от компонентов пищи. Жирная пища, продукты питания, содержащие натуральные пищевые волокна, а также оксалаты, фосфаты, фитаты (соли фитиновой кислоты) ухудшают всасывание Mg. Напротив, витамин D, а также паратгормон паращитовидных желез улучшают этот процесс. Всосавшийся внутрь $\mathrm{Mg}$ с током крови разносится по органам и тканям и распределяется в них неравномерно: $60 \%$ откладывается в костях и зубах, $20 \%$ в мышцах. Еще 19 \% приходится на органы, несущие на себе повышенную функциональную нагрузку: сердце, почки, печень, головной мозг. Оставшийся $1 \%$ содержится во внеклеточной жидкости, в том числе 0,3 \% в плазме и $0,5 \%$ в эритроцитах. Из всего $\mathrm{Mg}$, находящегося в плазме, 75 \% пребывает в ионизированной форме, $22 \%$ - связано с высокомолекулярными белками-глобулинами, $3 \%$ - с низкомолекулярными альбуминами. Выводится он через почки. Благодаря сложным регуляторным механизмам при недостаточном поступлении $\mathrm{Mg}$ или при повышении потребности в нем всасывание облегчается, а выделение через почки снижается. Если он поступает в повышенных количествах, то, наоборот, затрудняется всасывание и усиливается его выделение почками. 


\section{Физиологические функции}

Название данного металла созвучно с другим латинским словом, Magnum, что означает большой, великий. Действительно, магний в нашем организме является великим и в буквальном, и в образном смысле. Он великий, ведь его действительно много. По содержанию в организме человека занимает 4-е место, уступая лишь натрию, калию и Са. Он сосредоточен внутри клеток, и во внутриклеточной среде является самым важным макроэлементом после калия. Велика роль и в поддержании на должном уровне физиологических процессов, регулировании состояния органов и систем. Биологическая ценность $\mathrm{Mg}$ в значительной степени обусловлена антагонизмом с другим макроэлементом, Са. Подобно $\mathrm{Mg}$, Са относится к щелочноземельным металлам II группы. Поэтому оба минерала обладают сходством химической структуры и свойств. Этим сходством и обусловлено их конкурентное соперничество во влиянии на физиологические процессы, причем во многих случаях оно противоположно. Разумеется, это не значит, что Са является «плохим» макроэлементом, а $\mathrm{Mg}$ - «хорошим». Все неоднозначно, и Са для организма человека также незаменим. Он обеспечивает проведение нервных импульсов, укрепляет опорно-двигательный аппарат, формирует тонус сосудов и выполняет другие, не менее важные функции. $\mathrm{Mg}$ регулирует обмен Са. При низком содержании Са он усиливает всасывание этого макроэлемента и тормозит выведение с мочой. А при большом содержании Са его всасывание под действием минерала тормозится.

Противостояние между $\mathrm{Ca}$ и $\mathrm{Mg}$ в наибольшей степени проявляется на клеточном и субклеточном уровне. В противоположность магнию Са является внеклеточным элементом, и его концентрация во внеклеточном пространстве примерно в 25 раз превышает таковую внутри клетки. Разница или градиент концентрации Са по обе стороны клеточной мембраны поддерживаются ферментом кальцийзависимой АТФ-азой. Этот фермент 
выталкивает кальций наружу, и таким способом поддерживает градиент. Однако некоторая часть кальция все-таки проникает внутрь клеток. Перенос ионов Са осуществляется специфическими белками-переносчиками, так называемыми кальциевыми каналами. Проникая внутрь мышечных клеток, Са инициирует взаимодействие сократительных белков, актина и миозина. Со стороны скелетных мышц это сопровождается их сокращением. Аналогичные процессы происходят в сердечной мышце, в результате чего увеличивается сила сердечных сокращений. Благодаря тоническим сокращениям гладких мышц артериол АД поддерживается на должном уровне. Кроме того, кальций наряду с другими факторами обеспечивает проведение импульсов по нервным волокнам и их последующую передачу на мышцы. Но иногда эти и другие жизненно важные процессы приобретают патологически черты с развитием заболеваний. И в этих случаях на помощь приходит $\mathrm{Mg}$. Будучи сходен с $\mathrm{Ca}$, он конкурентно блокирует кальциевые каналы на клеточных мембранах. Спазм артериол под действием Са сопровождается повышением АД. Это один из механизмов развития гипертонической болезни. $\mathrm{Mg}$ расслабляет артериолы и снижает АД у гипертоников. Помимо повышения АД Са вызывает ряд других негативных эффектов со стороны сердечно-сосудистой системы. Он активирует специфические ферменты, которые запускают агрегацию тромбоцитов с формированием внутрисосудистых тромбов. Другие кальцийзависимые ферменты повреждают эндотелий, внутрисосудистую стенку и способствуют отложению на ней низкоплотного холестерина в виде атеросклеротических бляшек. Спазм сердечных или коронарных сосудов на фоне тромбоза и атеросклероза сопровождается ишемией, недостаточным притоком крови к миокарду. Под действием Са сократимость миокарда повышается, и, соответственно, возрастает его потребность в кислороде. Формируется своего рода порочный круг: спазм тромботическая и атеросклеротическая закупорка - повышение потребности в кислороде - ишемия с исходом в инфаркт. Сами 
по себе эти изменения - уже катастрофа. Но ситуация отягощается так называемым феноменом обкрадывания. Кровь устремляется по нормальным сосудам в неповрежденные участки, минуя зоны ишемии. В результате ишемизированная ткань еще больше обкрадывается кислородом, и ее площадь расширяется. $\mathrm{Mg}$ помогает разорвать этот порочный круг. Он блокирует кальцийзависимые ферменты, тем самым расширяет коронарные сосуды и препятствует образованию внутрисосудистых тромбов, доказано его антиатерогенное действие. Под действием $\mathrm{Mg}$ снижается уровень общего холестерина, главным образом за счет его низкоплотной фракции, и триглицеридов, ответственных за формирование атеросклеротических бляшек. $\mathrm{Mg}$ ускоряет расщепление не только холестерина, но и других липидов (жиров), и тем самым препятствует развитию ожирения и связанных с ним заболеваний, гипертонической болезни и сахарного диабета. Вообще антидиабетический эффект у $\mathrm{Mg}$ довольно выражен. Этот минерал повышает активность некоторых ферментов, запускающих процессы гликолиза, распада глюкозы.

Помимо $\mathrm{Ca}, \mathrm{Mg}$ регулирует обмен других макроэлементов, натрия и калия. Калий - внутриклеточный элемент, а натрий - внеклеточный. Градиент натрия и калия по обе стороны клеточной мембраны поддерживается магнийзависимым ферментом натрий-калиевой АТФ-азой. Поскольку $\mathrm{Mg}$ регулирует баланс ионов натрия, калия, и Са, он тем самым способствует правильной генерации и распространению импульсов в проводящей системе сердца. Велика его роль в профилактике тахиаритмий (нарушений ритма сердца с учащением частоты сокращений) - наджелудочковой и желудочковой экстрасистолии, пароксизмальной тахикардии, мерцательной аритмии. Некоторые из этих аритмий представляют опасность для жизни. $\mathrm{Mg}$ угнетает активность ренин-ангиотензин-альдостероновой системы (РААС). Действие этой системы направлено на повышение АД путем спазма артериол и задержки натрия в организме. Замедленное выведение натрия с мочой, задержка его в организме 
сопровождаются развитием отеков, застойной сердечной недостаточностью на фоне повышенного АД. Он в значительной степени устраняет эти негативные эффекты. Он замедляет реабсорбцию натрия в почечных канальцах. В результате выделение натрия почками усиливается, вместе с натрием выделяется вода, повышается диурез и объем выделенной мочи. Кроме того, натрий расширяет просвет почечных артерий. В результате усиливаются фильтрационные процессы почках, что также способствует повышению диуреза. Диуретическое действие $\mathrm{Mg}$ способствует устранению отеков и дополнительно снижает АД.

Аналогичным образом он влияет на состояние ЦНС и периферических нервов. Расширяя церебральные сосуды, он улучшает кровоснабжение мозговой ткани. Кроме того, $\mathrm{Mg}$ замедляет развитие церебрального атеросклероза и тромбоза и тем самым предотвращает развитие инсультов. А при развившихся инсультах он снижает тяжесть патологических изменений, связанных с феноменом обкрадывания. Способствует скорейшему восстановлению ЦНС после перенесенных инсультов и черепно-мозговых травм. В ЦНС кальций активирует проведение и распространение возбуждающих импульсов по нервным волокнам и их передачу на скелетные мышцы. Этот механизм лежит в основе появления судорог и такого тяжелого заболевания, как эпилепсия. У здоровых людей возбуждение в ЦНС, запущенное Са, проявляется бессонницей и негативными эмоциями тревоги, страха, неуверенности себе, а также раздражительностью и гневом. $\mathrm{Mg}$ как антагонист кальция оказывает седативное тормозное влияние на ЦНС и устраняет эти эмоции. В связи с этим его иногда образно называют минералом спокойствия. При этом он выступает в качестве природного противосудорожного средства. Эти эффекты $\mathrm{Mg}$ в значительной степени обусловлены его влиянием на выделение и захват ацетилхолина и норадреналина, основных нейромедиаторов.

Его действие не ограничивается одним лишь антагонизмом с Са. Этот макроэлемент входит в состав около 600 белковых соединений. Его функция контролируется примерно 280 генами, 
и он участвует в более чем 500 биохимических реакциях. $\mathrm{Mg}$ через натрий-калийзависимую АТФ-азу способствует расщеплению АТФ в митохондриях с выделением энергии. Благодаря тому, что он синхронизирует процессы окислительного фосфорилирования и клеточного дыхания, эта энергия расходуется более экономно. В результате клетки тканей становятся более устойчивыми к дефициту кислорода, к гипоксии.

Данный минерал позитивно влияет на состояние опорнодвигательного аппарата. Если при многих патологических состояниях магний является антагонистом кальция, то здесь он его синергист и союзник. $\mathrm{Mg}$ регулирует выделение гормона кальцитонина щитовидной железой (ЩЖ) и параттгормона паращитовидными железам и тем самым способствует откладыванию солей кальция в костной ткани.

Особое значение этот механизм имеет в детском и подростковом возрасте, в период роста и формирования костного скелета. В более зрелом возрасте $\mathrm{Mg}$ уменьшает риск развития остеопороза. Опасность этой патологии возрастает у женщин из-за дисгормональных нарушений, связанных с климаксом и приемом оральных контрацептивов.

$\mathrm{Mg}$ стабилизирует состояние ДНК, транспортных РНК, осуществляющих биосинтез белка, и стимулирует образование многих белковых соединений. Под его действием синтезируются белки - коллаген и эластин, которые обеспечивают прочность соединительнотканных структур - костей, связок, сухожилий. Кроме того, он повышает прочность и эластичность кожи.

ЖКТ тоже контролируется Mg. Как антагонист Са этот макроэлемент расслабляет гладкую мускулатуру ЖКТ, контролирует ее перистальтику и предотвращает появление спастических болей. Кроме того, $\mathrm{Mg}$ нормализует кислотность желудочного сока, стимулирует выделение пищеварительных соков двенадцатиперстной кишкой и поджелудочной железой. На образование желчи в печени $\mathrm{Mg}$ также влияет позитивно. Под его действием улучшается способность печени связывать и выводить токсины. Влияет на выделение некоторых солей, в частности уратов и ок- 
салатов, а также препятствует образованию нерастворимых солей кальция. Поэтому он предотвращает камнеобразование в желчевыводящей системе и в почечных лоханках.

Угнетает выделение гистамина тучными клетками и таким способом предупреждает появление аллергических реакций с явлениями кожной сыпи и бронхоспазма. Этот макроэлемент активирует клеточный и гуморальный иммунитет, так как способствует образованию Т- и В-лимфоцитов, повышает фагоцитарную активность нейтрофилов и тканевых макрофагов.

Помимо этого, $\mathrm{Mg}$ обладает свойствами онкопротектора. Он снижает вероятность развития многих видов злокачественных опухолей.

\section{Содержание в продуктах, суточные нормативы потребления}

В организме взрослого человека содержится в среднем 25 г $\mathrm{Mg}$, но это количество может варьироваться от 20 до 30 г. Суточная потребность в $\mathrm{Mg}$ зависит от пола, возраста и от некоторых других факторов (табл. 5).

Таблица 5

\section{Суточная потребность магния}

\begin{tabular}{|l|c|}
\hline \multicolumn{1}{|c|}{ Категория } & Суточная потребность, мг \\
\hline Дети до 6 мес. & 30 \\
\hline Дети 6-12 мес. & 75 \\
\hline Дети 1-3 лет & 80 \\
\hline Дети 4-8 лет & 130 \\
\hline Дети 9-13 лет & 240 \\
\hline Подростки-юноши & 410 \\
\hline Подростки-девушки & 360 \\
\hline Мужчины 19-30 лет & 400 \\
\hline Мужчины старше 30 лет & 420 \\
\hline Женщины 19-30 лет & 310 \\
\hline Женщины старше 30 лет & 320 \\
\hline Беременные женщины & $360-400$ \\
\hline Кормящие женщины & $320-360$ \\
\hline
\end{tabular}


При подборе диеты следует учитывать количественное содержание $\mathrm{Mg}$ в продуктах питания и его биодоступность. Так, свежие овощи, фрукты, зелень (петрушка, укроп, зеленый лук), орехи нового урожая обладают максимальной концентрацией и активностью магния. Избранные пищевые источники $\mathrm{Mg}$ представлены в табл. 6.

Т аблица 6

\section{Содержание магния в продуктах питания}

\begin{tabular}{|l|c|}
\hline \multicolumn{1}{|c|}{ Продукт } & Содержание, мг/100 г \\
\hline Пшеничные отруби & 448 \\
\hline Необработанные ростки пшеницы & 239 \\
\hline Тыквенные семечки & 534 \\
\hline Семечки подсолнечника & 129 \\
\hline Жареный миндаль & 286 \\
\hline Кофе в зернах & 200 \\
\hline Чай & 440 \\
\hline Какао 20\%-ное & 442 \\
\hline Соевые бобы & 240 \\
\hline Сырая гречка & 231 \\
\hline Лесные орехи & 310 \\
\hline Фундук & 172 \\
\hline Грецкие орехи & 100 \\
\hline Свежий шпинат & 79 \\
\hline Сушеные финики & 84 \\
\hline Шиповник сушеный & 120 \\
\hline Гречневая крупа & 231 \\
\hline Хлопья овсяные & 130 \\
\hline Курага & 47 \\
\hline Чернослив & 45 \\
\hline Арбуз & 224 \\
\hline Сыр & 35 \\
\hline Брынза & 23 \\
\hline Треска & 30 \\
\hline Сардины консервированные & 34 \\
\hline Баранина & 25 \\
\hline Говядина & 22 \\
\hline Мясо курицы & 20 \\
\hline Молоко 3,2\%-ное & 10 \\
\hline
\end{tabular}


Окончание табл. 6

\begin{tabular}{|l|c|}
\hline \multicolumn{1}{|c|}{ Продукт } & Содержание, мг/100 г \\
\hline Молочный шоколад & 63 \\
\hline Картофель & 25 \\
\hline Лук зеленый, репчатый & 20 \\
\hline Хлеб белый пшеничный & 23 \\
\hline Хлеб ржаной & 40 \\
\hline Зеленый горошек & 33 \\
\hline
\end{tabular}

\section{Эпидемиология}

Питание современного человека характеризуется деформацией минерального состава рациона с преобладанием потребления натрия хлорида при дефиците солей и лигандных композиций калия, $\mathrm{Mg}$, Са. Причины дефицита $\mathrm{Mg}$ связаны с изменением технологий сельского хозяйства, качества продуктов питания и образа жизни современных людей. Качественное изменение состава пищи, увеличение доли животных продуктов за счет растительных, высокое потребление белков и жирная пища повышают потребность в $\mathrm{Mg}$, при этом в результате дополнительной переработки и рафинирования многие продукты его утрачивают.

При длительном дефиците $\mathrm{Mg}$ развиваются заболевания, сопряженные с дефицитом макроэлемента. В данной популяции людей отмечена высокая частота следующих состояний: депрессия, гипертоническая болезнь, бронхиальная астма, остеопороз, диабет, заболевания ЖКТ, повышенная нервная, эмоциональная и физическая напряженность, болезни зависимости (курение, алкоголизм, наркомания). В ряде эпидемиологических исследований, проводимых в разных географических регионах, была выявлена обратная связь между содержанием магния в питьевой воде и частотой ишемической болезни сердца (ИБС).

Также существуют гендерные различия гомеостаза $\mathrm{Mg}$. Женщины более чувствительны к дефициту $\mathrm{Mg}$ и в норме имеют более высокие депонированные концентрации магния. Это связано с активным участием $\mathrm{Mg}$ в процессе деторождения. 


\section{Симптомы дефицита и избытка}

До недавних пор дефициту $\mathrm{Mg}$ не придавали особого значения. Но, как оказалось, это отклонение встречается довольно часто, и его последствия более серьезны, чем принято полагать. Немаловажную роль в магниевом дефиците играет пищевой фактор. Проблема в том, что в последнее время многие продукты не содержат его необходимого количества. Причина связана с обеднением магнием почв из-за ежегодного истощения, мелиоративных работ, нерационального использования удобрений, применения ядохимикатов. Если здоровая натуральная пища не способна удовлетворить потребность в этом макроэлементе, что тогда следует говорить о погрешностях в питании.

В этих случаях к дефициту $\mathrm{Mg}$ могут привести многие причины:

- рафинированные продукты, в том числе и еда быстрого приготовления, содержат минимальное количество $\mathrm{Mg}$;

- жирная пища затрудняет его всасывание;

- для усваивания белков необходим Mg. Поэтому прием белковой пищи сопровождается его усиленным расходом;

- то же самое касается сладостей, ведь Mg участвует в утилизации поступившей глюкозы для подержания нормогликемии;

- прием кофе, чая, и других напитков, содержащих кофеин. При этом $\mathrm{Mg}$ усиленно выводится с мочой;

- прием пищи с большим количеством консервантов, усилителей вкуса и прочих синтетических ингредиентов;

- прием продуктов, богатых Са, фосфатами;

- «лечебное» голодание, при котором он вообще не поступает в организм.

Наряду с пищевым фактором существует и водный. Насыщение организма макроэлементом в немалой степени зависит от жесткости воды. Жесткость формируют соли кальция и магния. Поэтому прием мягкой воды, бедной солями $\mathrm{Mg}$, влечет за собой 
магниевый дефицит. Именно такая вода подается в городскую водопроводную сеть после очистки, в ходе которой удаляется большинство минеральных соединений. Этому же способствует фторирование воды, после которого магниевые соли выпадают в нерастворимый осадок.

Помимо пищевого и водного факторов есть лекарственный. Лекарства некоторых групп негативно влияют на содержание $\mathrm{Mg}$ в организме. Это:

- комбинированные оральные контрацептивы, синтетические эстрогены;

- диуретики;

- слабительные;

- глюкокортикостероиды;

- антибиотики.

Разумеется, однократное или непродолжительное использование этих средств едва ли отразится на концентрации $\mathrm{Mg}$ в организме человека. Но их длительное употребление приведет к уменьшению данного макроэлемента.

Вредные привычки, алкоголь и курение предрасполагают к дефициту Mg. То же самое касается других видов хронических интоксикаций промышленными и бытовыми ядами.

Еще один причинный фактор: заболевания ЖКТ, при которых нарушается всасывание поступившего извне $\mathrm{Mg}$ или же происходит его усиленная потеря из-за диареи. Он теряется с потом. Поэтому обильное потоотделение при физическом труде, спортивных тренировках, при работе в горячих цехах будет сопровождаться потерей этого макроэлемента.

Кроме физических нагрузок к повышенному расходу $\mathrm{Mg}$ предрасполагают следующие состояния:

- умственные нагрузки;

- стрессовые ситуации;

- период роста;

- беременность и лактация. 
Усиленный расход $\mathrm{Mg}$ отмечается при некоторых заболеваниях, среди которых:

- сахарный диабет, особенно 2-го типа на фоне ожирения;

- ИБС, перенесенный инфаркт миокарда;

- гипертоническая болезнь;

- болезни почек с нарушением их выделительной функции;

- нарушение функции щитовидной и паращитовидных желез;

- последствия тяжелых травм;

- цирроз печени;

- гиперальдостеронизм, гиперпаратиреоидизм, гипертиреоидизм.

Если не восполнять потери извне, в органах и тканях формируется недостаток $\mathrm{Mg}$. Это состояние негативно сказывается на состоянии тканей и систем органов. Влияние на сердечнососудистую систему заключается в развитии ИБС с частыми приступами стенокардии, развитии гипертонической болезни, повышении риска инфаркта миокарда, тахиаритмий, застойной сердечной недостаточности с периферическими отеками. Кроме того, из-за нарушения синтеза коллагена могут развиваться клапанные пороки, в том числе и пролапс митрального клапана.

Со стороны ЦНС - это общая слабость, головные боли, головокружение, нарушения сна, депрессия. Ухудшение ментальных функций: снижение памяти, слабая концентрация внимания, плохие аналитические способности. Отклонения в эмоционально-волевой сфере: страх, раздражительность, неуверенность в себе, депрессия. Возрастает риск инсультов, болезни Паркинсона, болезни Альцгеймера.

Происходит снижение мышечной силы и выносливости. Возможно развитие нервно-мышечной гипервозбудимости, включая мышечные судороги, в дальнейшем тетания, генерализованные судороги, головокружение и мышечная слабость. Эти симптомы связаны с ролью $\mathrm{Mg}$ в передаче нервно-мышечной возбудимости и сокращении мышц. Другие симптомы дефицита магния могут включать усталость, вялость, шаткую походку 
и потерю аппетита, судороги в различных мышечных группах, усиливающиеся при эмоциональном волнении и при физических нагрузках, остеопороз, частые переломы костей.

Возможно поражение ЖКТ в виде затруднения глотания, болей в области желудка и кишечника спастического характера, диспепсических расстройств (тошнота, отрыжка, изжога после приема пищи), чередование запоров и поносов.

Дефицит Mg влияет на органы чувств, приводя к снижению остроты зрения и слуха.

Нарушаются обменные процессы в организме. Происходит понижение температуры тела, формируется низкая толерантность к холоду, склонность к отекам, гиперальдостеронизм, снижение толерантности к глюкозе, алкоголю, никотину, сгущение желчи, камни в желчном пузыре, почках, нарушение формирования соединительной ткани, остеопороз, остеопения, остеоартроз, остеохондроз, кальцификация магнийдефицитных тканей (атеросклеротических бляшек, участков плаценты), постстрессорная полиурия, накопление токсических металлов. Развивается сахарный диабет 2-го типа на фоне ожирения.

Избыток в клинической практике наблюдается редко, так как Mg, не накапливаясь, выводится почками. Для формирования избытка $\mathrm{Mg}$ необходимо одно из двух условий или их сочетание: усиленное бесконтрольное поступление $\mathrm{Mg}$ в составе препаратов или замедление его выделения из-за патологии почек. При этом отмечаются следующие симптомы: общая слабость, заторможенность, сонливость, плохая координация движений, снижение мышечного тонуса, сухость во рту, жажда, боли в животе, тошнота, диарея, снижение АД, брадикардия, уменьшение частоты сердечных сокращений. Все эти симптомы неспецифичны.

В литературных обзорах представлено несколько перекрестных исследований, которые показали положительную связь между потреблением $\mathrm{Mg}$ или концентрацией $\mathrm{Mg}$ в сыворотке крови и влиянием на мышечную силу и мышечную производительность. Физические упражнения оказывают влияние на рас- 
пределение и утилизацию $\mathrm{Mg}$ (Mg транспортируется в места, где происходит выработка энергии, в ответ на физические упражнения), a Mg необходим для сокращения мышц и поддержания кардиореспираторных функций. Кроме того, при физических нагрузках потребность в $\mathrm{Mg}$ увеличивается и обмен веществ ускоряется. Неоптимальный или недостаточный уровень $\mathrm{Mg}$ у испытуемых, участвующих в программах силовых тренировок, может быть связан с менее эффективным энергетическим метаболизмом и снижением выносливости. Напротив, более высокое потребление магния связано с более низкой потребностью в кислороде и лучшими кардиореспираторными показателями при аэробных упражнениях.

Об избыточном содержании $\mathrm{Mg}$ говорит гипермагниемия, повышение его содержания в плазме крови. Нормальные значения $\mathrm{Mg}$ находятся в пределах 0,7-1,1 ммоль/л. Клинические проявления начинаются уже при гипермагниемии 1,5 ммоль/л. При значениях 2,5-5 ммоль/л развиваются выраженные изменения в сердечно-сосудистой системе с гипоксией в тканях. Дальнейшее превышение этих показателей принимает угрожающий для жизни характер, а при содержании $\mathrm{Mg}$ в крови 7,5 ммоль/л происходит остановка сердца.

\section{Участие в репродукции}

Нормальное содержание $\mathrm{Mg}$ в организме является важным условием нормального функционирования женской репродуктивной системы, включая регулярность менструального цикла, наличие овуляции, способность к зачатию, нормальной беременности и даже либидо. К приоритетным элементам, оказывающим наиболее важное влияние на женскую половую сферу, относятся в первую очередь $\mathrm{Mg}$, Са, селен, медь, цинк, кадмий и железо.

По данным О.А. Громовой, до 63,3 \% женщин с предменструальным синдромом имеют пограничный и умеренный дефицит 
$\mathrm{Mg}$, подтверждаемый клиническими проявлениями магния и лабораторным исследованием $\mathrm{Mg}$ в двух биосредах (кровь, волосы).

У здоровых женщин уровень $\mathrm{Mg}$ в крови находится в диапазоне нормы или субнормы и имеет четкий месячный ритм. Женщины с предменструальным синдромом имеют патологический биоритм уровня $\mathrm{Mg}$ в сыворотке крови с усилением проявления дефицита во второй фазе цикла и во время менструации.

\section{Акушерские и перинатальные результаты дефицитарных состояний}

Беременная женщина подвержена развитию дефицита $\mathrm{Mg}$, так как потребность в нем возрастает в 2-3 раза и составляет 500-700 мг в сутки. Повышенная потребность в Mg связана с рядом факторов: развивающийся плод получает $\mathrm{Mg}$ из организма матери, происходит увеличение матки от 100 до 1000 г, увеличение общей массы крови (увеличение количества эритроцитов) на 20-30\%, набухание молочных желез, высокий уровень эстрогенов, повышение уровня альдостерона.

К акушерским факторам и причинам гипомагниемии относят гестозы, угрозу прерывания беременности, плацентарную недостаточность, гипотрофию плода, гиповитаминоз D, юный возраст первородящих, частые (менее двух лет) и многократные роды, стрессы, антифосфолипидный синдром при терапии диуретиками. По данным FIGO, беременность у юных первородящих - это фактор риска по недостаточной минерализации костей и низкому содержанию $\mathrm{Mg}$ в грудном молоке, в сравнении с матерями в репродуктивном возрасте. Причем применение поливитаминов для беременных не может обеспечить достаточное поступление $\mathrm{Mg}$ для юных первородящих.

Дефицит Mg при беременности приводит к различным осложнениям у матери и плода, таким как ЗРП, преждевременные роды (ПР) и ПЭ. Эклампсия - наиболее грозное осложнение бе- 
ременности, соответствующее пику магниевого дефицита, пику спазмофилии, гипомагниемии; данное осложнение гестации является показанием для срочной терапии $\mathrm{Mg}$ по жизненным показаниям, утвержденной ВО3.

Существует ряд специфических признаков гипомагнезиемии при беременности:

- угроза прерывания на протяжении всей беременности;

- ПЭ;

- ПР

- нарушение процессов раскрытия шейки матки в родах;

- нарушение периода изгнания в родах (нарушение сократительной активности матки);

- боли в спине и пояснице; боли и чувство тяжести в области костно-мышечного апоневроза в тазовом отделе у беременных женщин;

- эклампсия.

Гипомагнезиемия при беременности также оказывает влияние на плод и приводит к развитию гипотрофии плода. Различают два механизма участия $\mathrm{Mg}$ в патогенезе синдрома ЗРП: недостаточная передача $\mathrm{Mg}$ от матери к плоду через плаценту и нарушение объема циркулирующей плазмы и необходимость синтеза белка. Дефицит $\mathrm{Mg}$ у плода приводит к нарушению энергообмена клеток и усилению трансмембранного обмена. Снижение синтеза Mg-АТФ-азы у беременных с дефицитом $\mathrm{Mg}$ приводит к вазоконстрикции и развитию хронической плацентарной недостаточности. Дефицит Mg в тканях плаценты способствует образованию кальцификатов и старению плаценты.

Выделяют следующие клинические признаки гипомагнезиемии у плода: хромосомные и генетические аномалии; эмбриональные пороки развития (недостаточность формирования соединительной ткани), анемия у плода, фетальный отек, недоношенность, недостаточность и замедление развития плода, гипотрофия плода, повышенный риск развития асфиксии, повышенный риск развития внутриутробной инфекции. 


\section{Способы лабораторной диагностики}

Нормы содержания $\mathrm{Mg}$ в сыворотке крови: у взрослых 0,75-1,26 ммоль/л, у беременных 0,8-1,05 ммоль/л, у детей 0,74-1,15 ммоль/л. Гипомагнезиемия у взрослых: умеренная недостаточность - 0,5-0,7 ммоль/л, выраженная недостаточность менее 0,5 ммоль/л. Уровень $\mathrm{Mg}$ в сыворотке крови может сохраняться в нормальных пределах, даже при снижении общего количества магния в организме на 80 \%. Поэтому снижение магния в сыворотке крови является признаком выраженного дефицита $\mathrm{Mg}$ в организме.

Показания к проведению анализа определения уровня магния в сыворотке крови:

- неврологическая патология (тетания, гипервозбудимость, тремор, судороги, гипотония мышц);

- почечная недостаточность;

- аритмия;

- оценка состояния щитовидной железы (гипотиреоз);

- надпочечниковая недостаточность.

Проводят определение $\mathrm{Mg}$ методом абсорбции с ксилидилом синим на автоанализаторе. Забор крови осуществляется из локтевой вены в количестве 3 мл. Кровь на анализ берется строго натощак, с 8:00 до 10:00. Согласно циркацианному ритму магния в плазме крови, это время отражает среднюю концентрацию магния в плазме за сутки; исключается пищевой подъем уровня $\mathrm{Mg}$. Взятая кровь после забора подвергается центрифугированию не позднее 30-60 мин, так как отделение плазмы от клеток в более поздние сроки приводит к выходу $\mathrm{Mg}$ в плазму из разрушающихся форменных элементов крови (эритроцитов, тромбоцитов и т.д.), что имитирует ложнонормальный и даже повышенный уровень Mg. Даже начало гемолиза дает повышенные уровни $\mathrm{Mg}$ в крови и использоваться для тестирования не может.

Норма $\mathrm{Mg}$ может оцениваться в различных клетках. При этом они не только по-разному концентрируют магний (лимфо- 
циты $>$ фагоциты $>$ тромбоциты $>$ эритроциты). Изменение уровня $\mathrm{Mg}$ в разных клетках помогает интерпретировать уровень нарушения магниевого баланса.

\section{Варианты коррекции}

Самый известный препарат - это сернокислая магнезия $\left(\mathrm{MgSO}_{4}\right)$. Препарат выпускают в ампулах с содержанием 25\%-ного раствора и в виде порошка для приема внутрь. Инъекционное введение показано при сердечно-сосудистой, неврологической и акушерско-гинекологической патологии: гипертоническая болезнь, экстрасистолия, пароксизмальная тахикардия, последствия инсультов и черепно-мозговых травм, мозговые дисфункции, ПЭ и эклампсия. Сернокислая магнезия в порошке принимается внутрь как слабительное средство, а также при отравлении солями тяжелых металлов.

Присутствует $\mathrm{Mg}$ в комбинированных средствах. Его сочетают с витамином $\mathrm{B}_{6}$ («Магне $\mathrm{B}_{6} »$, «Магнелис $\left.\mathrm{B}_{6} »\right)$, с ацетилсалициловой кислотой («Кардиомагнил»), с витамином $\mathrm{B}_{13}$ или оротовой кислотой («Магния оротат», «Магнерот»). В этих и других препаратах он присутствует в виде цитрата, лактата, оксида, гидроксида, хлорида и других соединений.

Усваиваемость этих соединений различна. Например, магния гидроксид $\left(\mathrm{Mg}(\mathrm{OH})_{2}\right)$ вообще практически не всасывается. Это соединение обладает антацидными свойствами, реагирует с соляной кислотой желудочного сока и снижает кислотность. магния гидроксид включен в состав многих антацидных обволакивающих средств, в том числе таких известных, как «Маалокс», «Алмагель».

Еще один важный фактор: наличие других ингредиентов в комбинированных средствах. Са в таких средствах может негативно сказываться на усваивании $\mathrm{Mg}$. Оптимальное соотношение между этими двумя элементами - 2:1 в сторону увеличе- 
ния $\mathrm{Mg}$. Кристаллогидрат хлорида магния, $\mathrm{MgCl}_{2} \cdot 6 \mathrm{H}_{2} \mathrm{O}$ более известен как «Бишофит». Его используют как наружное средство в виде ванн, аппликаций, компрессов, при заболеваниях опорно-двигательного аппарата, в частности при остеохондрозе и при деформирующем остеоартрозе.

\section{Взаимодействие с другими веществами}

$\mathrm{Mg}$ способствует усваиванию Са. Однако в большом количестве наблюдается обратный эффект, так как оба минерала конкурируют друг с другом. Оптимальное соотношение $\mathrm{Mg}: \mathrm{Ca}$ должно быть 2:1. Он несовместим с железом. Фосфор и марганец ухудшают всасывание $\mathrm{Mg}$. А он, в свою очередь, затрудняет всасывание фосфора.

$\mathrm{Mg}$ облегчает усваивание витаминов группы В, за исключением витамина $\mathrm{B}_{1}$. Витамин $\mathrm{E}$ в сочетании с ним тоже плохо усваивается. Витамин $\mathrm{D}_{3}$ улучшает его всасывание в кишечнике. Наличие витамина $\mathrm{B}_{9}$ приводит к его повышенному расходу. То же самое касается жиров, углеводов. Пищевые волокна ухудшают его всасывание. Прием алкоголя сопровождается усиленным выведением $\mathrm{Mg}$ через почки

Таким образом, нормальный уровень $\mathrm{Mg}$ признан основополагающей константой, контролирующей здоровье человека. $\mathrm{Mg}$ влияет на функционирование органов и систем на всех этапах его развития. При этом у населения России недостаточность $\mathrm{Mg}$ занимает одну из лидирующих позиций, наряду с распространенностью дефицита йода, кальция и цинка, и требует коррекции назначением магниевых диет и фармакологических препаратов. 


\section{ЖЕЛЕ3О}

Железо (лат. - Ferrum, Fe) - один из самых распространённых в земной коре металлов, занимающий второе место после алюминия.

Для живых организмов железо является одним из 15 эссенциальных (жизненно необходимых) микроэлементов, играет ключевую роль в процессах метаболизма, роста и пролиферации клеток. Fe входит в состав ферментов в виде комплекса - гема (гем - простетическая часть молекулы гемоглобина и миоглобина), присутствующего, в частности, в гемоглобине. Комплексы железа, отличные от гема, встречаются, например, в ферменте метан-моноксигеназе, окисляющем метан в метанол, в ферменте рибонуклеотид-редуктазе, который участвует в синтезе дезоксирибонуклеиновой кислоты (ДНК). Неорганические соединения железа встречаются в некоторых бактериях и используется ими для связывания азота из воздуха.

Возможно, первое железо, с которым столкнулись наши далекие предки, было неземного происхождения. Ведь железные метеориты - не редкость, и места их падения располагаются практически повсеместно. Человек по достоинству оценил прочность и пластичность найденного металла. Но по мере развития цивилизации его явно не хватало. И наши предки научились разрабатывать железные руды и извлекать из них металл. В результате на смену бронзовому веку пришел железный. Из железа начали изготавливать орудия труда, оружие. Это нашло отображение даже в античной мифологии. Согласно тогдашним представлениям, покровителем железа был бог войны Марс, и одноименная красная планета обеспечивала его образование в земной коре. В течение последующих столетий способы добычи и обработки металла лишь совершенствовались. Была разработана технология изготовления сплавов углерода с железом (чу- 
гуна, стали), а также сплавов с другими металлами (ферросплавов), отличающихся повышенной прочностью и устойчивостью к коррозии.

$\mathrm{Fe}$ в периодической системе элементов Менделеева располагается в VIII группе 4-го периода и значится под № 26. Его атомная масса составляет 56. Внешне это серебристо-белый металл. Он легко поддается различным способам обработки: ковке, резке, прокатке, шлифованию. А еще оно обладает магнитными свойствами. Металл довольно тяжел, его плотность составляет 7,87 г $\mathrm{cm}^{3}$. Температуры плавления и кипения высоки и составляют $1538,85^{\circ}$ и $2861^{\circ} \mathrm{C}$ соответственно. Примечательно, что нагревание до высоких температур сопровождается изменением кристаллической структуры железа, его магнетизма и прочих свойств. В нормальных условиях оно обладает переменной валентностью, которая составляет II или III, но может повышаться до VI. Металл обладает высокой реакционной способностью и легко вступает во взаимодействие с другими соединениями, в частности с кислородом, образуя с ним окиси. Данные окиси это не что иное, как ржавчина. Она покрывает металл, но из-за своей рыхлости не предотвращает его дальнейшую коррозию. Однако, если нагреть металл до высоких температур, он покрывается плотной защитной оксидной пленкой. В чистом кислороде оно горит. Помимо кислорода металл реагирует с галогенами, некоторыми сильными кислотами, образуя соли. Чистого железа в природе мало, и, как правило, оно метеоритного происхождения. В основном металл представлен соединениями. Многие железосодержащие соединения имеют характерный желтый, красный или коричневый окрас. Содержание его в земной коре составляет около 4,45 \% от его массы. Таким образом, по распространенности оно занимает 4-е место среди всех элементов и 2-е среди металлов, уступая лишь кислороду, кремнию и алюминию. Находящееся в земном ядре железо формирует магнитные полюса Земли. Но оно присутствует не только в неорганической материи. Это важнейший элемент всего живого мира. 
У млекопитающих и представителей других классов животных железо включено в состав гемоглобина эритроцитов. Растения используют его для образования зеленого хлорофилла, необходимого для фотосинтеза. А морской и океанический планктон потребляет ежегодно до полумиллиарда тонн железа - примерно столько, сколько его выплавляют все металлургические заводы планеты в течение года.

В организме здорового человека содержится около 3-5 г железа. Большая часть $\mathrm{Fe}$ (около 3,5 г) входит в состав клеток крови и костного мозга, 600 мг содержатся в макрофагах различных типов, 1 г - в клетках печени и лишь около 400 мг железа входят в состав других клеток организма. Практически все железо находится в связанном с белками состоянии; свободные ионы $\mathrm{Fe}$, если и присутствуют, то в крайне низких концентрациях.

\section{Основы метаболизма}

$\mathrm{Fe}$ в организме человека не синтезируется. Около 1-2 мг железа, поступающего с пищей, ежедневно абсорбируется в кишечнике (наиболее интенсивно - в двенадцатиперстной и начальных отделах тощей кишки, в желудке - не более 1-2 \%). Железо в пище находится в форме $\mathrm{Fe} 3+$. B процессе прохождения железа через апикальную и базолатеральную мембраны абсорбирующих эпителиальных клеток участвуют два вида транспортных белков. Негемовое железо переносится интестинальным дивалентным катионом DMT1 (divalentmetaltransporter 1), гемовое IREG1/ferroportin/MTP1 (ironregulated protein1/ferroportin/metaltransporter protein1). Мембраносвязанная железоредуктаза двенадцатиперстной кишки понижает степень окисления до $\mathrm{Fe} 2+$, затем происходит захват Fe DMT1 и проникновение в энтероциты, откуда транспортными белками ферропортином и гефестином экспортируется в плазму, где связывается с трансферрином.

Гемовое железо освобождается от белковых цепей в ЖКТ и в виде металлопорфирина всасывается энтероцитами кишеч- 
ника. Внутри клетки происходит расщепление гема гем-оксигеназой-1 с высвобождением Fe2+. Далее, с помощью IREG1/ferroportin/MTP1, ионы окисляются до Fe3+, связываются с трансферрином и покидают энтероцит. Трансферрин - белок плазмы крови, осуществляющий внеклеточный транспорт железа из кишечника, печени, селезенки (места его всасывания или освобождения) в костном мозге. Уровень железа в организме регулирует гормон гепсидин: если содержание железа в организме избыточно, оно задерживается в энтероцитах и в дальнейшем удаляется из организма вместе со слущивающимся кишечным эпителием.

В составе трансферрина железо поступает через систему воротной вены в печень, где часть железа остается в гепатоцитах (запасной фонд в составе внутриклеточного ферритина). Большая часть железа транспортируется в костный мозг - к местам синтеза гемоглобина. Меньшая часть Fе доставляется другим клеткампотребителям (активно пролиферирующие клетки с высокой потребностью в железе) для синтеза ДНК, РНК и железосодержащих ферментов. В транспорте железа принимает участие также лактоферрин - железосвязывающий гликопротеин, который абсорбирует железо из интестинальных эпителиальных клеток, а затем также транспортирует его к печени и другим органам.

Депонирование железа осуществляется ферритином белком, который преимущественно содержится в макрофагах костного мозга, печени и селезенке. В случае избытка железа в организме ферритин преобразуется в гемосидерин. Основную железодепонирующую функцию выполняет ферритин печени. Ферритин системы фагоцитирующих макрофагов абсорбирует железо, которое высвобождается после деструкции энтероцитов, для его реутилизации.

Из костного мозга в составе эритроцитов железо поступает в кровоток, где циркулирует в течение времени функционирования нормальных эритроцитов (3-4 месяца). В дальнейшем состарившиеся или поврежденные эритроциты захватываются макрофагами селезенки и печени и разрушаются. При этом высвобождается Fe, 
которое вновь поступает в плазму, связывается с трансферрином и отправляется к эритроидным клеткам костного мозга. Ежедневно для эритропоэза требуется около 20-30 мг Fe, тогда как ежедневное поступление пищевого $\mathrm{Fe}$ из кишечника составляет всего 1-2 мг. Необходимые 20-30 мг железа ежедневно возвращаются в циркуляцию. Процесс рециркуляции Fе имеет гораздо большее физиологическое значение, чем всасывание Fe в кишечнике.

В кровотоке может циркулировать и некоторое количество $\mathrm{Fe}$, связанного не с трансферрином, а с другими белками плазмы (например альбумином). Содержание такого железа в плазме нарастает при развитии перегрузки железом, по мере заполнения им всего свободного трансферрина.

Интенсивность всасывания железа из ЖКТ регулируется количеством этого микроэлемента, поступающего с пищей (алиментарный регулятор), его общим содержанием в организме (депо-регулятор или регулятор запасов железа), а также активностью эритропоэза в костном мозге (эритроидный регулятор).

Пусковую роль в развитии анемии играют различные экзогенные (инфекции, токсины) и эндогенные факторы, в результате чего уменьшается всасывание $\mathrm{Fe}$ в кишечнике, нарушаются рециркуляция и освобождение $\mathrm{Fe}$ из тканевых запасов и, как следствие, нарушается синтез эритроцитов.

Наследственные дефекты метаболизма Fe приводят к неконтролируемому всасыванию и избыточному накоплению железа и развитию гемохроматоза.

\section{Физиологические функции}

Молекулярное железо обладает выраженными токсическими свойствами, в связи с чем в живом организме оно всегда связано с белками. Исключительная роль Fе определяется важными биологическими функциями белков, в состав которых оно входит:

- гемоглобин и миоглобин (62 и 8 \% пула железа в организме человека); 
- цитохром Р-450 и прочие ферменты, участвующие в процессах биологического окисления;

- пероксидазы, каталазы, цитохромы - ферменты, нейтрализующие активные формы кислорода и поддерживающие окислительно-восстановительный баланс в организме.

Гемоглобин состоит из глобина - белковой части и небелкового цветообразующего вещества (гема), содержащего желе30. В молекуле гемоглобина содержится четыре гема, соединенных белковой цепочкой. Гем включает один атом двухвалентного железа, который может присоединить два атома кислорода. Значительное количество $\mathrm{Fe}$ в организме находится в составе миоглобина. В молекуле миоглобина содержится только один гем. В моллекуле миоглобина доля железа составляет 0,34 \%, а в молекуле гемоглобина - 0,334 \%. Миоглобин, подобно кислороду, способен легко и быстро связываться с кислородом. Депонирование кислорода миоглобином играет важную роль в процессе сокращения мышечных волокон, которое возможно только в присутствии значительного количества кислорода. Количество миоглобина в мышечной ткани находится в прямой зависимости от концентрации гемоглобина, которая в свою очередь зависит от количества Fе в организме.

Благодаря своим уникальным свойствам (быстро окисляться и восстанавливаться), Fе катализирует процессы транспорта электронов и окисление - восстановление органических субстратов. Поддержание уровня концентрации гема внутри клетки важно для регуляции гидроксилирования каскадного переноса электронов по дыхательной цепи. В мышечной ткани млекопитающих содержится железосодержащий пигмент цитохром, который принимает участие в окислительном фосфорилировании и тканевом дыхании, в результате которых происходит превращение внутренней энергии пищевых веществ в энергию биологической динамики - роста, размножения, регенерации. Окислительно-восстановительные реакции с участием цитохромов происходят в клетках постоянно, в результате чего образуются вода и мочевина, которые выводятся из организма. 
Избыток свободного железа приводит к локальному повреждению тканей за счет усиления окислительных процессов и повышенного образования свободных радикалов, инициирующих цитотоксические эффекты, а также за счет размножения бактерий, вирусов, грибов, использующих Fе хозяина. В составе ферментов оксидаз клеток головного мозга $\mathrm{Fe}$ осуществляет нормальное функционирование нейротрансмиттерных систем с участием дофамина, серотонина и $\gamma$-аминомасляной кислоты (ГАМК). Дофамин, являясь основным нейротрансмиттером экстрапирамидной системы, поддерживает когнитивные и аффективные реакции, а серотонин и ГАМК-эргические системы регулируют поведение, сон, двигательную активность, эмоциональный тонус.

$\mathrm{B}$ настоящее время изучается влияние Fe на течение тяжелых инфекционных и нейродегенеративных заболеваний. Так, повышенное содержание железа в макрофагах больных ВИЧинфекций является плохим прогностическим признаком и отрицательно коррелирует с продолжительностью жизни; при повышении содержания $\mathrm{Fe}$ у больных гепатитом C наблюдается худший ответ на терапию и повышенная частота трансформации в цирроз печени. У пациентов с болезнью Альцгеймера, болезнью Паркинсона, рассеянным склерозом отмечается локальная перегрузка железом, что приводит к окислительному повреждению нейронов головного мозга.

Избыточное содержание железа сопряжено с цитотоксическими эффектами, которые обусловлены способностью железа как металла с переменной валентностью запускать цепные свободнорадикальные реакции, приводящие к перекисному окислению липидов биологических мембран, токсическому повреждению белков и нуклеиновых кислот (гемохроматоз).

Специализированный негемовый железосерный белок нуклеинового обмена - рибонуклеотидредуктаза отвечает за преобразование нуклеозид дифосфата в дезоксинуклеозиддифосфат, обеспечивая сбалансированное участие в синтезе ДНК. Этот фермент железозависимый, а субъединица рибонуклеотидредуктазы содержит $\mathrm{Fe}$, необходимое для ферментативной ак- 
тивности комплекса, задействованного в процессах репликации ДНК, клеточной пролиферации и дифференцировки. О ключевой роли $\mathrm{Fe}$ в процессах регуляции активности генов, которые принимают участие в онтогенезе, свидетельствуют результаты недавно проведенных исследований Американским институтом по изучению рака. Так, при изучении колоректального рака было установлено, что у 8 из 10 больных раком отмечалась депрессия гена APC (adenomatouspolyposiscoli), являющегося опухолевым супрессором, функциональная активность которого регулируется уровнем железа в организме. Выяснение роли железа в синтезе нуклеиновых кислот и пролиферации клеток дало толчок новому направлению в развитии противоопухолевой терапии, мишенью которой становится внутриклеточное железо.

\section{Содержание в продуктах, суточные нормативы потребления}

Суточная потребность в Fе зависит от пола, возраста и от некоторых других факторов (табл. 7).

Т а бли ца 7

\section{Суточная потребность в железе}

\begin{tabular}{|l|c|c|}
\hline \multicolumn{1}{|c|}{ Пол } & Возраст & $\begin{array}{c}\text { Рекомендованное потребление } \\
\text { железа (мг/сут) }\end{array}$ \\
\hline Младенцы & До 6 месяцев & 0,27 \\
\hline Младенцы & $7-12$ месяцев & 11 \\
\hline Дети & $1-3$ года & 7 \\
\hline Дети & $4-8$ лет & 10 \\
\hline Подростки & $9-13$ лет & 8 \\
\hline Юноши & $14-18$ лет & 11 \\
\hline Девушки & $14-18$ лет & 15 \\
\hline Мужчины & 19 лет и старше & 8 \\
\hline Женщины & $19-50$ лет & 18 \\
\hline Женщины & 50 лет и старше & 8 \\
\hline Беременные женщины & - & 27 \\
\hline Кормящие женщины & - & 9 \\
\hline
\end{tabular}


Наиболее богаты $\mathrm{Fe}$ печень и красное мясо, в меньшей степени яйца, бобовые, семена тыквы и кунжута, цельнозерновые крупы, а также некоторые виды зелени - тимьян, петрушка, полевой салат. Долгое время список железосодержащих продуктов возглавлял ошибочно внесённый в него шпинат.

$\mathrm{Fe}$ в продуктах питания присутствует в гемовой (из мяса и других животных источников) и негемовой (из растительной пищи) формах. В гемсодержащих белках Fe находится в составе гема. В негемовых железосодержащих белках $\mathrm{Fe}$ непосредственно связывается с белком. Гемовое железо усваивается наиболее эффективно (от 15 до 35 \%). Большая часть поступающего с пищей Fе является негемовым. Заметно улучшают всасывание $\mathrm{Fe}$ потребляемая вместе с пищей аскорбиновая, молочная, янтарная кислоты, животные белки; препятствуют - яйца, Са, фитиновая кислота, оксалаты, танины, пищевые волокна, кофеин и полифенолы (бобы, орехи, чай, сыр и некоторые овощи). В конечном итоге, благодаря высокой биодоступности, гемовое железо является основным пищевым источником этого микроэлемента. Вегетарианцам советуют принимать примерно в 1,8 раза больше железа, чем невегетарианцам (табл. 8).

Т а блица 8

\section{Содержание железа в продуктах питания}

\begin{tabular}{|l|c|}
\hline \multicolumn{1}{|c|}{ Продукт } & Содержание, мг $/ 100$ г \\
\hline Морская капуста & 16,0 \\
\hline Чечевица (зерно) & 11,8 \\
\hline Соя (зерно) & 9,7 \\
\hline Печень & 6,9 \\
\hline Горох (зерно) & 6,8 \\
\hline Гречка ядрица & 6,7 \\
\hline Баранина & 6,6 \\
\hline Орехи & $5,0-2,3$ \\
\hline Язык говяжий & 4,1 \\
\hline Хлеб ржаной & $3,9-3,1$ \\
\hline Геркулес & 3,6 \\
\hline Шпинат & 3,5 \\
\hline
\end{tabular}


Окончание табл. 8

\begin{tabular}{|l|c|}
\hline \multicolumn{1}{|c|}{ Продукт } & Содержание, мг 100 г \\
\hline Мясо кролика & 3,3 \\
\hline Курага, инжир свежий & 3,2 \\
\hline Конина & 3,1 \\
\hline Чернослив & 3,0 \\
\hline Пшено, кукуруза (крупа) & 2,7 \\
\hline Говядина & 2,7 \\
\hline Хурма & 2,5 \\
\hline Груша свежая & 2,3 \\
\hline Яблоко свежее & 2,2 \\
\hline Щавель & 2,0 \\
\hline Мясо курицы & 1,6 \\
\hline Мясо индейки & 1,4 \\
\hline Скумбрия & 1,7 \\
\hline Капуста цветная & 1,4 \\
\hline Свекла & 1,4 \\
\hline Капуста брюссельская & 1,3 \\
\hline Земляника, малина & 1,2 \\
\hline Сазан & 0,6 \\
\hline Судак & 0,5 \\
\hline Хек/треска & 0,5 \\
\hline
\end{tabular}

Многим женщинам трудно получить достаточное количество железа из своего рациона, чтобы иметь достаточные запасы для беременности. Согласно рекомендациям FIGO, в регионах с высокой частотой анемии (>20\% женщин) всем менструирующим женщинам рекомендуется периодически принимать (один раз в неделю) 60 мг элементарного железа в сочетании с фолиевой кислотой. Однако следует отметить, что избыток железа, хотя и маловероятен при такой дозировке, может быть вредным и предрасполагать к малярийной инфекции. В районах, эндемичных по малярии, добавки железа следует назначать в сочетании с профилактическим приемом противомалярийных препаратов. 


\section{Эпидемиология}

Около 1 млрд женщин репродуктивного возраста страдают от дефицита железа, на долю реализованной железодефицитной анемии (ЖДА) приходится ещё около 700 млн человек. В мировом масштабе за последние годы распространенность анемии резко возросла среди небеременных женщин репродуктивного возраста - с 464 млн в 2000 г. до 578 млн в 2016 г. В странах с низким и средним уровнем дохода общая распространенность анемии превышает 35 \%. В Индии, например, до $88 \%$ беременных и $74 \%$ небеременных женщин страдают анемией, в Африке - соответственно 50 и $40 \%$, в Латинской Америке и Карибском бассейне - 40 и 30 \%. По мнению экспертов ВОЗ, распространенность ЖДА в популяции может быть умеренной - от 5 до 19,9\%, средней - от 20 до 39,9 \% и значительной $-40 \%$ и более. При распространенности анемии более $40 \%$ проблема перестает быть только медицинской и требует принятия мер на государственном уровне. В средней полосе России латентным дефицитом железа страдают 13,5 \% женщин, в ряде регионов нашей страны (Северный Кавказ, Восточная Сибирь) этот показатель достигает 50-60\%.

Среди детского населения России ЖДА регистрируется у 6-40\%. Ряд исследований показывает, что адекватный айрон-статус у девочек в подростковом возрасте помогает более быстрой компенсации недостаточности железа во время беременности.

Распространенность ЖДА у беременных прогрессирует с увеличением срока гестации, составляя по уровню гемоглобина 21-80 \% и 49-99 \% - по уровню сывороточного железа. Тяжелая анемия может увеличивать риск материнской смертности в родах. 


\section{Симптомы дефицита и избытка}

Дефицит железа является наиболее распространенным алиментарным дефицитом и самой частой причиной анемии в мире.

Недостаток железа подразделяют на:

- прелатентный дефицит;

- латентный дефицит железа без анемии;

- железодефицитную анемию (ЖДА).

Прелатентный дефицит характеризуется снижением тканевых запасов Fe без уменьшения его расходования на эритропоэз. Клинических проявлений эта стадия не имеет. Единственным лабораторным критерием этой стадии является снижение уровня ферритина в сыворотке крови $(<20$ мкг/л).

Латентный дефицит наблюдается при полном истощении запасов Fе в депо, при отсутствии клинических признаков анемического синдрома. Однако при этом уже могут отмечаться различные симптомы сидеропенического синдрома.

В группу риска развития дефицита Fе входят пациентки:

- подросткового возраста;

- имевшие беременность / лактацию в течение предыдущих трех лет;

- имеющие высокий паритет;

- с осложненным течением предыдущих беременностей (многоплодие, ПЭ, предлежание плаценты, преждевременная отслойка нормально расположенной плаценты);

- с низким социально-экономическим статусом;

- с недостаточным содержанием Fе в пищевом рационе (вегетаринство, веганство, православные посты, хроническое недоедание/голодание);

- с обильными менструациями (объём месячной кровопотери более 100 мл);

- с гинекологическими заболеваниями (миома матки, эндометриоз); 
- с заболеваниями ЖКТ (гастрит, язвенная болезнь желудка и двенадцатиперстной кишки, варикозное расширение вен пищевода, неспецифический язвенный колит, дивертикулы, геморрой и др.);

- со злокачественными новообразованиями;

- страдающие ожирением;

- регулярные доноры крови.

Проживание в высокогорных регионах и курение повышают показатели гемоглобина, тем самым маскируя проявления железодефицита.

Выявление нормального уровня гемоглобина не означает отсутствия латентного железодефицита, так как в первую очередь снижается содержание железа в депо, затем транспортная функция и лишь после этого синтез гемоглобина.

На этапе латентного дефицита у пациентки развивается сидеропенический синдром, который обусловлен тканевым дефицитом железа, играющим важную роль в качестве кофермента многих метаболических процессов в различных органах и тканях. В большей степени страдают эпителиальные ткани, нуждающиеся в быстром обновлении, включая кожу и слизистые оболочки. Уровень гемоглобина при латентном дефиците железа остается нормальным, в связи с чем это состояние часто остается нераспознанным.

Сидеропенический синдром включает такие клинические симптомы, как:

- извращение вкуса, пристрастие к острой, соленой, пряной пище, пациенты едят мел, уголь, глину, золу и / или сырые продукты: крупы, мясной фарш, сырое тесто;

- пристрастие к необычным запахам: керосина, мазута, бензина, ацетона, гуталина, нафталина, выхлопных газов машин, которые полностью проходят на фоне приема препаратов железа;

- сухость кожи;

- изменение ногтей; 
- выпадение волос;

- ангулярный стоматит;

- жжение языка;

- хейлит;

- дисфагия;

- диспептический синдром;

- мышечная слабость, снижение общей толерантности к физической нагрузке;

- нарушения метаболических процессов в миокарде;

- ощущение сердцебиения;

- одышка;

- расстройства периферического кровообращения и микроциркуляции;

- жжение и зуд вульвы.

На стадии ЖДА, когда возникают клинические проявления анемического синдрома и в общем анализе крови - снижение уровня $\mathrm{Hb}$, количества эритроцитов и цветового показателя. Анемический синдром обусловлен тканевой гипоксией, его проявления универсальны для всех видов анемий.

По распространенности среди анемий одно из ведущих мест занимают гипохромные анемии - ЖДА и анемия хронических заболеваний. В основе развития гипохромных анемий лежит дефицитный эритропоэз с нарушением дифференцировки эритроидных клеток и созревания эритроцитов, всегда сопровождающийся нарушением обмена железа: нарушения всасывания и / или использования железа (ЖДА), нарушения утилизации железа (талассемия, сидеробластные анемии), нарушения реутилизации железа (анемия хронических заболеваний).

Клиническая картина ЖДА включает в себя: сидеропенический синдром, общую слабость, быструю утомляемость, затруднение в сосредоточении внимания, сонливость, головную боль после переутомления, головокружение, обмороки (при тяжелой анемии), бледность кожных покровов, иногда с легким зеленоватым оттенком (хлороз) и с легко возникающим 
румянцем щек, сухость, дряблость кожи, шелушение, легко образующиеся трещины, изменения ногтей: истончение, матовость, расслоение, ломкость, исчерченность; при выраженных изменениях ногти приобретают вогнутую, ложкообразную форму (койлонихия).

Избыточное содержание железа в организме - гемохроматоз. Первичный гемохроматоз - наследственное, генетически обусловленное заболевание, проявляющееся нарушением обмена железа с избыточным его накоплением, что приводит к перекисному окислению липидов биологических мембран, токсическому повреждению белков и нуклеиновых кислот. Вторичный - связан с кризами гемолитической и мегалобластной анемий, многократными переливаниями крови, нерациональным назначением препаратов железа. Накопление $\mathrm{Fe}$ в паренхиматозных органах характеризуется дегенеративными изменениями клеточной паренхимы и прогрессирующим развитием фиброзной ткани, что ведет к необратимому нарушению функции жизненно важных органов (печень, поджелудочная железа и сердце). Гемохроматоз диагностируется у мужчин в 5-10 раз чаще, чем у женщин, обычно в возрасте 40-60 лет, у женщин - в большинстве случаев после менопаузы, так как в репродуктивном возрасте избыток железа у женщин удаляется из организма во время менструаций и беременности.

Клиническая картина гемохроматоза включает суставные боли, артрит, выраженное похудение, вялость, апатию, выпадение волос, гиперпигментация кожи, фиброз печени с трансформацией в цирроз, фиброз коры поджелудочной железы, надпочечников, передней доли гипофиза, щитовидной железы, сахарный диабет, снижение либидо. 


\section{Участие в репродукции}

Латентный дефицит железа является одним из факторов, негативно влияющих на результативность программ экстракорпорального оплодотворения (ЭКО). Наличие латентного дефицита усугубляет неблагополучное течение индуцированных беременностей. В частности, у таких пациенток значительно выше частота угрозы выкидыша, ранних репродуктивных потерь и дисбиоза влагалища. Кроме того, более чем в $50 \%$ случаев при наличии латентного дефицита развивается ЖДА к концу первого триместра гестации.

Fе входит в состав 100 геминовых ферментов, в том числе в семейство цитохромов и гидроксилаз. Именно цитохром Р-450 активный фермент стероидогенеза, без его участия не синтезируется ни один половой гормон и витамин $\mathrm{D}_{3}$. Монооксигеназная система цитохрома Р-450 играет важную роль в метаболизме ксенобиотиков, синтезе эндогенных биологически активных веществ, таких как стероидные гормоны, холестерин и простагландины. При дефиците Fe происходит снижение кислородной емкости крови (гемическая гипоксия) - снижение концентрации гемоглобина в эритроцитах и, как следствие, нарушение тканевого дыхания и повышенная атрезия фолликулов. Таким образом, дефицит $\mathrm{Fe}$ может провоцировать атрезию фолликулов и нарушение стероидогенеза.

Влияние дефицита $\mathrm{Fe}$ на метаболизм йода в щитовидной железе связано с понижением активности гемсодержащей тиреопероксидазы. Дефициты Fе и йода часто сочетаются, особенно у беременных и у подростков. Высокая распространенность ЖДА в районах эндемического зоба может снизить эффективность восполнения йодного дефицита. Дефициты меди и $\mathrm{Fe}$ негативно воздействуют на гипоталамо-гипофизарно-тиреоидную ось гормональной регуляции, утяжеляя течение йоддефицитных заболеваний. По сравнению с женщинами с нормальным состоянием депо железа, относительный риск гипотиреоза в восемь раз выше у женщин с истощенным депо железа. 


\section{Акушерские и перинатальные результаты дефицитарных состояний}

Потребность в железе во время беременности увеличивается по сравнению с прегравидарным периодом по сравнению с другими микронутриентами. Фактором риска по заболеваемости ЖДА во время беременности является уровень железа до наступления беременности (у 40-60\% женщин детородного возраста запасы железа истощены).

В период гестации расход железа резко возрастает из-за увеличивающихся потребностей плода и плаценты. К 28-30 неделям физиологически протекающей беременности у женщины неизбежно развивается анемия, связанная с неравномерным увеличением объема циркулирующей плазмы крови (500 мг) и объема эритроцитов, депонированием железа в фетоплацентарном комплексе (450 мг). Потеря железа возникает также в родах, послеродовом периоде (150 мг), при лактации (400 мг). ЖДА сопровождается развитием гемической гипоксии, которая способствует активации перекисного окисления липидов и цитокинового стресса, что приводит к эндогенной интоксикации. Этот механизм рассматривается как один из основных при развитии акушерских осложнений.

Накопление железа в организме плода происходит наиболее интенсивно после 28-й недели гестации, вследствие чего недоношенные дети составляют группу риска по развитию дефицитных состояний. В третьем триместре плоду требуется дополнительно 9-12 мг Fe, что составляет дополнительно 1000-1240 мг к рациону беременной.

При выраженной некорригированной анемии на ранних сроках беременности непроисходит трансформация спиральных артерий, в них сохраняется гладкомышечный слой (в норме - исчезает). Такие сосуды не способны обеспечить быстро растущие потребности в кровоснабжении, в результате чего развивается фетоплацентарная недостаточность и, как следствие, гипоксия плода. 
Во время беременности и родов тяжёлая анемия увеличивает риск развития преэклампсии (40-50\%), преждевременных родов (11-42\%), нарушений родовой деятельности - дискоординации родов, затяжных, стремительных родов (10-35 \%), атонических и гипотонических кровотечений (10\%).

Плацентарная недостаточность и железодефицитное состояние приводят к внутриутробной задержке роста и развития плода (ЗРП), низкой оценке новорождённого по Апгар, синдрому дыхательных расстройств, аномалиям родовой деятельности, обусловливающим родовой травматизм (до 27 \%). В раннем неонатальном периоде наблюдается большая потеря массы тела и более медленное ее восстановление, запоздалое отпадение пупочного остатка, длительное течение физиологической желтухи.

Запасы железа, содержащиеся у каждого ребенка при рождении (70-75 мг/кг), будут полностью израсходованы к 4-6 месяцам, когда вес ребенка удвоится. На сегодняшний день уже чётко доказана положительная корреляция между железодефицитом и умственными и физическими способностями детей, нарушением роста и низкой устойчивостью к инфекциям младенцев. Исключительно грудное вскармливание играет значительную роль в профилактике развития ЖДА у детей раннего возраста. Содержащийся в грудном молоке лактоферрин способствует высокой абсорбции Fе из молока, несмотря на невыское его содержание (0,2-0,4 мг/л). Вследствие этого у доношенных детей, находящихся на грудном вскармливании, до полугода ЖДА, как правило, не развивается. В дальнейшем потребность детей в Fе увеличивается до 10 мг/сут в связи с возрастающей потребностью в гемоглобинообразовании, депонировании в тканях, ростом и пролиферацией клеток. Содержащегося в грудном молоке Fe будет недостаточно для поддержания его положительного баланса.

Угнетение иммунной системы на фоне ЖДА повышает уровень материнской смертности $(6,2 \%)$ и перинатальной гибели плода (60\%). 


\section{Способы лабораторной диагностики микроэлементного статуса}

В соответствии с федеральными клиническими рекомендациями скрининг для выявления анемии, начиная с подросткового возраста, необходимо проводить у всех небеременных женщин каждые 5-10 лет в течение всего детородного возраста. Ежегодному скринингу подлежат женщины с факторами риска развития дефицита железа.

В качестве скрининга в период прегравидарной подготовки рекомендуется оценка клинического анализа крови (гемоглобин в норме 120-140 г/л; среднее содержание гемоглобина в эритроците (МСH, норма 28-32 пг); средний объём эритроцита (MCV, норма 80-100 фл); анизоцитоз (RDW, норма до 15\%); количества тромбоцитов и лейкоцитов.

Нормальный уровень гемоглобина: более 120 г/л у небеременных, более 110 г/л - у беременных женщин). Единственным лабораторным критерием прелатентного дефицита Fе является снижение уровня ферритина в сыворотке крови $(<20$ мкг/л)

Пациенткам из групп риска развития дефицита $\mathrm{Fe}$ рекомендовано определение:

- сывороточного Fe (отражает количество железа, транспортирующегося в данный момент к клеткам-потребителям);

- ферритина сыворотки крови (внутриклеточный белок, связывающий до 20 \% общего количества железа в организме. В физиологических условиях уровень отражает запасы железа в организме: снижение $\leq 40$ мкг/л характерно для истинного железодефицита, повышение > 1000 мкг/л - для гемохроматоза);

- трансферрина (повышение отражает усиленный синтез в ответ на тканевой дефицит железа; снижение - перегрузку железом или нарушение белково-синтетической функции печени);

- насыщения трансферрина Fe (расчетный показатель, который вычисляется отношением показателя сывороточного железа к общей железосвязывающей способности сыворотки и в нор- 
ме составляет 20-40\%. При железодефицитных состояниях насыщение трансферрина железом снижается, при перегрузке железом - значительно превышает нормальные значения).

Критерии диагностики латентного дефицита Fe:

- клинический анализ крови (снижение MCH, MCV, анизоцитоз, пойкилоцитоз, анизохромия);

- снижение сывороточного Fe;

- увеличение трансферрина;

- снижение ферритина менее 30 мкг/л;

- снижение насыщение трансферрина Fе менее 20 \%;

- повышение общей железосвязывающей способности сыворотки.

Критерии диагностики ЖДА:

- клинический анализ крови (снижение концентрации гемоглобина, цветового показателя, MCH, MCV, увеличение RDW (иногда и количества тромбоцитов), микроцитоз, гипохромия эритроцитов);

- снижение уровня сывороточного Fe;

- повышение общей железосвязывающей способности сыворотки;

- снижение содержания ферритина в сыворотке.

В настоящее время ЖДА не имеет собственной классификации по степеням тяжести, а для клинической работы используется стандартное для всех анемий разделение на степени тяжести: легкая уровень гемоглобина выше 90 г/л; средней тяжести - гемоглобин в пределах 90- 70 г/л; тяжелая - уровень гемоглобина менее 70 г/л.

Критерии диагностики гемохроматоза:

- повышение уровня ферритина (> 1000 нг/мл);

- повышение содержания сывороточного Fe;

- повышение насыщения трансферрина железом (> 45 \%);

- повышение уровня ферритина (у мужчин > 300 мкг/л, у женщин $>200$ мкг/л);

- повышение аминотрансфераз;

- снижение общей железосвязывающей способности сыворотки крови $(<28$ мкмоль/л). 


\section{Варианты коррекции}

Решение о дотации $\mathrm{Fe}$ должно быть основано на данных лабораторной показателей. Назначение препаратов железа абсолютно всем женщинам не рекомендуется.

Женщинам из группы риска развития латентного дефицита с нормальными лабораторными показателями показаны:

- адекватный интергенетический интервал (2-4 года);

- регуляция менструального цикла (снижение патологической кровопотери) с применением гормональных контрацептивов;

- лечение острых и компенсация хронических заболеваний ЖКТ;

- рациональное питание (с обязательным включением в рацион животного белка);

- профилактическое назначение препаратов железа в дозе не менее 60 мг в неделю (три месяца приём, три месяца перерыв).

Коррекцию латентного дефицита $\mathrm{Fe}$ проводят с помощью пероральных препаратов железа - 100 мг/сут в пересчёте на элементарное железо до нормализации показателей обмена железа (табл. 9).

Таблица 9

\section{Пероральные лекарственные препараты, содержащие железо}

\begin{tabular}{|l|l|}
\hline \multicolumn{1}{|c|}{ Монокомпонентные } & \multicolumn{1}{|c|}{ Сложные по составу } \\
\hline $\begin{array}{l}\text { Железа бисглицинат } \\
\text { Жезо хелат) }\end{array}$ & $\begin{array}{l}\text { Железа бисглицинат, фолиевая кислота, цианокобала- } \\
\text { мин («Фолифебин») }\end{array}$ \\
\hline & Железа глюконат, марганец, медь и др. («Тотема») \\
\hline & $\begin{array}{l}\text { Делеза сульфат и аскорбиновая кислота («Сорбифер- } \\
\text { Дурулес») }\end{array}$ \\
\hline & $\begin{array}{l}\text { Железа сульфат, аскорбиновая кислота, рибофлавин, } \\
\text { тиамина мононитрат, никотинамид, пиридоксина гид- } \\
\text { рохлрорид, пантотеновая кислота («Фенюльс») }\end{array}$ \\
\hline & $\begin{array}{l}\text { Железа сульфат и d, l-серин («Актиферрин») } \\
\text { («Тардиферон») }\end{array}$ \\
\hline & $\begin{array}{l}\text { Железа фумарат и фолиевая кислота («Ферретабком- } \\
\text { позитум») }\end{array}$ \\
\hline
\end{tabular}


Окончание табл. 9

\begin{tabular}{|l|l|}
\hline \multicolumn{1}{|c|}{ Монокомпонентные } & \multicolumn{1}{c|}{ Сложные по составу } \\
\hline $\begin{array}{l}\text { Железа (III) гидроксид поли- } \\
\text { мальтозный комплекс («Маль- } \\
\text { тофер», «Феррум Лек») }\end{array}$ & $\begin{array}{l}\text { Железа (III) гидроксид полимальтозный комплекс } \\
\text { и фолиевая кислота («Мальтофер Фол») }\end{array}$ \\
\hline $\begin{array}{l}\text { Железа протеин сукцинилат } \\
\text { «Ферлатум») }\end{array}$ & $\begin{array}{l}\text { Железа протеин сукцинилат+кальция фолинат } \\
\text { пентагидрат («Ферлатум фол») }\end{array}$ \\
\hline & Железа пирофосфат, витамин С («СидерАЛ форте») \\
\hline & $\begin{array}{l}\text { Железа пирофосфат, витамин С, витамин } \mathrm{B}_{12} \\
\text { (СидерАЛИнт») }\end{array}$ \\
\hline
\end{tabular}

Международные организации выступают за регулярное применение добавок $\mathrm{Fe}$ и фолиевой кислоты для каждой беременной женщины юного и репродуктивного возраста. Современные рекомендации для беременных женщин включают стандартную суточную дозу 30-60 мг элементарного Fе и 400 мкг фолиевой кислоты, чтобы уменьшить риск развития анемий и рождения детей с низкой массой тела. Причем необходимо начинать прием как можно раньше при наступлении беременности и в течение трех месяцев после рождения ребенка.

Если ежедневный прием Fe невозможен из-за побочных эффектов, а также если распространенность анемии среди беременных в популяции не превышает 20 \%, для улучшения материнских и неонатальных исходов беременным рекомендуется периодический прием внутрь препаратов Fев дозе 120 мг в пересчете на $\mathrm{Fe}$ один раз в неделю и фолиевой кислоты в дозе 2800 мкг (2,8 мг) один раз в неделю.

Основное лечение при выявлении причины развития ЖДА должно быть направлено на ее устранение (лечение энтерита, коррекцию алиментарной недостаточности и др.). Средствами выбора для коррекции дефицита железа и уровня гемоглобина у больных ЖДА являются лекарственные препараты железа. Им следует отдавать предпочтение перед пищевыми продуктами, содержащими Fe. 


\section{Селен}

Селен (лат. - Selenium, Se) открыл в 1817 г. шведский химик Берцелиус. Новый элемент был выделен им из отходов производства серной кислоты. В то время ученые-химики часто называли вновь открытые вещества именами героев древнегреческих мифов. Так появились уран, палладий, церий, названые в честь Урана, Паллады и Цереры. Берцелиус, следуя традициям, назвал новое вещество селеном в честь богини Луны Селены.

В таблице Менделеева Se располагается в VI группе 4-го периода под № 34. Данную группу именуют халькогенами, что в переводе с древнегреческого означает рудообразующие. В группу халькогенов помимо Se входят такие распространенные в природе вещества, как кислород и сера, а также менее известные теллур и полоний. Особенно велико сходство $\mathrm{Se}$ с серой. Как и у серы, у Se на внешней орбите вращаются шесть электронов, которые он может отдавать или присоединять при взаимодействии с атомами других элементов. Поэтому валентность y Se переменная: 2, 4 и 6. Существует несколько разновидностей или аллотропных модификаций Se. Самый стабильный и часто встречающийся - серый селен. Это хрупкое блестящее вещество

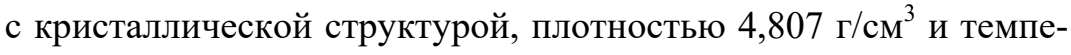
ратурой плавления $217^{\circ} \mathrm{C}$. Интересный факт: серый Se является полупроводником, и при освещении его электропроводность увеличивается в 1000 раз. Это его свойство нашло применение в технике, в производстве фотоэлементов. Другие аллотропные модификации - красный кристаллический и красный аморфный $\mathrm{Se}$, черный стекловидный $\mathrm{Se}$. B природе $\mathrm{Se}$ практически не встречается в чистом виде. Имея сходство с серой, он в большинстве случаев сочетается с ней. Se часто обнаруживают в качестве примеси к чистой вулканической сере. Он может быть включен в состав сульфидных минералов свинца, меди или цин- 
ка. Соединения Se рассеяны, и его содержание в земной коре невелико, всего лишь $5 \cdot 10^{-6} \%$. Se среди всех элементов таблицы Менделеева занимает 68-е место.

\section{Основы метаболизма}

B организм Se поступает в виде селеносодержащих аминокислот или неорганических соединений, селенитов и селенатов. Органический и неорганический Se всасывается в тонком кишечнике, преимущественно в двенадцатиперстной кишке.

Биологическая роль $\mathrm{Se}$ в организме человека реализуется посредством селенопротеинов (СП), выполняющих структурную и ферментативную роль за счет своей каталитической и антиоксидантной активности. Важность Se как необходимого микроэлемента связана с его ролью в качестве селеноцистеина в ряде селенопротеинов, включая антиоксидантные ферменты глутатионпероксидазы (GSH-Pxs), тиоредоксинредуктазы (TrxRs) и селенопротеина P (SELENOP или SePP). Эти ферменты защищают ткани от повреждающего действия активных форм кислорода (АФК) и других эндогенных продуктов клеточного метаболизма, вовлеченных в повреждение ДНК и потенциально приводящих к мутагенезу, гибели клеток и канцерогенезу. Механизмы антиоксидантной защиты играют центральную роль в модулировании процессов, опосредованных окислительным стрессом, который нередко наблюдается при осложненном течении беременности.

Селениты и селенаты ионизируются с образованием отрицательно заряженных ионов, анионов. Далее эти анионы вступают во взаимодействие со специфическим белком и восстанавливаются до селеноводорода. Он тоже находится в ионизированной форме, в виде аниона (гидроселенид-аниона). Далее гидроселенид-анион вступает во взаимодействие с селенсвязывающим белком и включается в состав селенопротеинов, участвующих в метаболических реакциях. Однако количество селен- 
связывающего белка ограничено. Поэтому излишек гидроселенид-анионов подвергается ферментативному метилированию и в виде метаболитов выводится с мочой и в небольшом количестве - с потом. При массивном поступлении селена в виде свободных гидроселенид-анионов он способен накапливаться в коже, волосах и внутренних органах (сердце, легкие, печень, почки, поджелудочная железа), а также в костном мозге, у мужчин в семенных пузырьках, оказывая токсическое действие.

\section{Физиологические функции}

Данный микроэлемент можно считать и ядом, и лекарством. Все зависит от количества и от пути поступления. Примечательно, что при первом знакомстве селен проявил себя именно с отрицательной стороны. Его считали ядовитым веществом, и причины для этого были. Дело в том, что полупроводниковые свойства $\mathrm{Se}$ нашли широкое применение в промышленности. При этом участились случаи отравления $\mathrm{Se}$, соединения которого в повышенных концентрациях содержались в воздухе производственных помещений. Однако во второй половине прошлого века появились научные разработки, в которых доказывалось, что Se необходим для нормальной жизнедеятельности. Содержание в организме Se невелико, не более 20 мг. Но без этого малого количества наступают большие проблемы. Подтверждением тому является факт, что прием пищи, богатой Se, или селенсодержащих препаратов заметно снижает частоту сердечнососудистых, онкологических и эндокринных заболеваний. В организме человека селен содержится в неорганической и в органической форме. Неорганический $\mathrm{Se}-$ в виде солей селеновой и селенистой кислот, селенитов и селенатов. Органический $\mathrm{Se}-$ это селенометионин и селеноцистеин. Здесь атом Se включен в структуру молекул аминокислот метионина и цистеина. Белки, в состав которых включены селеносодержащие аминокислоты, 
называют селенопротеинами. Многие гормоны, ферменты являются селенопротеинами.

\section{Содержание в продуктах, суточные нормы потребления}

Рекомендуемые нормы потребления Se для разных категорий населения представлены в табл. 10.

\section{Таблица 10}

\section{Суточная потребность в селене}

\begin{tabular}{|l|c|}
\hline \multicolumn{1}{|c|}{ Категория } & Суточная потребность, мкг \\
\hline Дети 0-6 мес. & 10 \\
\hline Дети 7-12 мес. & 15 \\
\hline Дети 1-6 лет & 20 \\
\hline Дети 7-10 лет & 30 \\
\hline Мальчики-подростки 11-14 лет & 40 \\
\hline Девочки-подростки 11-14 лет & 45 \\
\hline Юноши 15-18 лет & 50 \\
\hline Девушки 15-18 лет & 50 \\
\hline Мужчины & 70 \\
\hline Женщины & 55 \\
\hline Беременные женщины & 60 \\
\hline Кормящие женщины & 70 \\
\hline
\end{tabular}

Потребность в Se увеличивается при острых и хронических заболеваниях, инфекциях, травмах.

Чемпион по содержанию $\mathrm{Se}$ - бразильский орех. Но по вполне понятным причинам рассматривать его в качестве реального повседневного источника Se не стоит. Много макроэлемента содержится в мясных субпродуктах (печень, почки) в грибах, а также в зерновых кашах.

В табл. 11 представлено содержание Se в 100 г пищевых продуктов. 


\section{Содержание селена в продуктах питания}

\begin{tabular}{|l|c|}
\hline \multicolumn{1}{|c|}{ Продукт } & Содержание, мкг/100 г \\
\hline Свежий бразильский орех & 1500 \\
\hline Печень свиная & 53 \\
\hline Почки свиные жареные & 265 \\
\hline Сало свиное & 20 \\
\hline Печень говяжья & 40 \\
\hline Печень утиная & 68 \\
\hline Печень куриная & 55 \\
\hline Яйцо куриное & 32 \\
\hline Печень индюшиная & 71 \\
\hline Чеснок & 14 \\
\hline Осьминог & 44 \\
\hline Креветки & 45 \\
\hline Тунец & 12 \\
\hline Белый гриб сушеный & 105 \\
\hline Вешенки сушеные & 95 \\
\hline Семечки подсолнечные & 53 \\
\hline Кунжут & 34 \\
\hline Фасоль & 25 \\
\hline Соя & 17 \\
\hline Горох & 13 \\
\hline Пшеничные отруби & 78 \\
\hline Гречка & 13 \\
\hline Рис & 28 \\
\hline Ячневая крупа & 22 \\
\hline Перловка & 37 \\
\hline Овсяные хлопья & 12 \\
\hline
\end{tabular}

Следует заметить, что из растительных продуктов $\mathrm{Se}$ усваивается лучше, чем из животных. Микроэлемент чувствителен к кулинарной обработке. При варке, жарке его количество снижается вдвое, а при консервировании он теряется практически полностью. К тому же при варке, замораживании или замачивании продуктов очень много Se переходит в воду. 


\section{Эпидемиология}

Существует U-образная зависимость между концентрацией селена в крови и общей заболеваемостью, т. е. на заболеваемость влияет как недостаток, так и избыток Sе. Другими словами, дополнительное введение селена благоприятно при существующем его дефиците, но употребление дополнительно препаратов селена в отсутствие дефицита может приводить к различным побочным эффектам, например гипергликемии и ускорению прогрессирования атеросклероза.

$\mathrm{B}$ среднем содержание Se в почве составляет 0,4 мг/кг. Но эта цифра не постоянна. Она зависит от состава почвы, в том числе доли органических веществ в ней и количества осадков, выпадающих в данной местности. В горных районах (Финляндия, Швеция, Шотландия) в почвах выявляется недостаток селена, тогда как глинистые почвы и почвы в регионах с низким уровнем осадков обычно содержат повышенное количество этого микроэлемента. В большинстве стран Европы, Египте, Бразилии, Индии, Китае, Саудовской Аравии, Непале, Бурундии, Новой Гвинее выявлены отдельные регионы с дефицитом Se. Избыток Se также обнаружен в отдельных регионах Индии, Китая, США, Канады, Бразилии, Венесуэлы, Японии.

$\mathrm{Se}$ содержится не только в почве, но и в воде. В среднем концентрация Se в водопроводной воде составляет 10 мкг/л, что определено ВО3 как минимальный допустимый уровень $\mathrm{Se}$ в питьевой воде. В подводных водах концентрация Se несколько выше, но наибольшего уровня она достигает в морской воде, где составляет от 4000 до 12000 мкг Se на 1 л

\section{Дефицит и избыток}

Дефицит $\mathrm{Se}$ в организме может быть следствием ряда субъективных и объективных факторов. Субъективные факторы - это заболевания, различные патологические и физиологи- 
ческие состояния, при которых снижается поступление Se в организм или увеличивается его расход. Один из таких субъективных факторов - болезни ЖКТ. При заболеваниях печени, поджелудочной железы, желудка и тонкого кишечника ухудшается всасывание многих нутриентов, в том числе и Se. При почечной патологии возможно усиленное выведение данного микроэлемента. Некоторые состояния сопровождаются усиленным расходом Se: физический труд, занятия спортом перегревание, сопровождающееся обильным потоотделением, беременность и лактация (Se теряется с грудным молоком), бурный рост, половое созревание, тяжело протекающие хронические заболевания, восстановительный период после инфекций, травм, оперативных вмешательств.

На содержание Se негативно влияют некоторые лекарства: оральные контрацептивы, анаболические стероиды, нестероидные противовоспалительные средства (НПВС), статины, слабительные, энтеросорбенты. Разумеется, однократный или эпизодический прием этих средств вряд ли повлияет на содержание $\mathrm{Se}$ в организме. Но при частом или систематическом употреблении количество этого микроэлемента будет снижаться. То же самое будет происходить при злоупотреблении алкоголем, а также при нерациональном питании. Вегетарианская пища, безбелковые диеты, увлечение сладостями - все это способствуют дефициту Se. То же самое касается синтетических пищевых ингредиентов. Продукты длительного хранения с консервантами, зелень с нитратами, мясо животных, вскормленных гормональными биодобавками, содержат крайне низкое количество Se.

Что касается пищи, то здесь задействованы и объективные факторы. Суть в том, что в эксплуатируемых в течение многих десятков лет почвах количество Se уменьшается. Микроэлемент расходуется растениями, но человек не пополняет истощающиеся запасы. Селеновых удобрений практически нет. Более того, удобрения, содержащие фосфор и серу, еще больше снижают количество селена в почве. К тому же в процессе мелиоративной 
обработки почвы закисляются, и это тоже негативно сказывается на содержании в них Se. Соответственно, в растениях, идущих в пищу человеку или на корм животным, его практически нет. Загрязнение окружающей среды промышленными выбросами, содержащими соли тяжелых металлов, ароматические углеводороды, нитраты - еще одна причина низкого содержания Se. A есть такие регионы, где этот микроэлемент изначально, в силу естественных геологических особенностей, содержится в низких количествах. Среди этих регионов - северо-запад России, Прибалтика, Беларусь. Особенно остро данная проблема ощущается в Забайкалье, здешнее население часто страдает от нехватки Se.

Клинические признаки дефицита Se развиваются при суточном поступлении менее 5 мкг. Негативные изменения претерпевают все системы организма. Наиболее наглядно это проявляется в состоянии сердечно-сосудистой, иммунной и эндокринной систем. Из-за дистрофических процессов снижается сократимость миокарда, развивается сердечная недостаточность с застойными явлениями. На эндотелии артериальных сосудов откладываются атеросклеротические бляшки. Возрастает угроза ИБС и инсультов. Чем меньше в организме $\mathrm{Se}$, тем меньше йода. Ведь эти два микроэлемента являются синергистами, союзниками. В итоге страдает функция щитовидной железы. Уменьшается выработка тиреоидных гормонов (ТГ), развивается гипотирео3. Пациенты жалуются на общую слабость, сонливость, апатию, снижение физической и умственной работоспособности. Растет масса тела, развивается ожирение. Положение усугубляется еще и тем, что из-за снижения продукции инсулина поджелудочной железой и усиления резистентности к нему тканей развивается сахарный диабет. Все эти состояния, гипотиреоз, ожирение, сахарный диабет, дистрофия миокарда с атеросклерозом отягощают друг друга и формируют порочный круг. Из-за низкого иммунитета организм становится более восприимчивым к инфекциям. Правда, есть один любопытный факт. Ученые не 
без оснований предполагают, что проблема в данном случае не только в снижении иммунитета. У некоторых вирусов после попадания в организм с дефицитом Se перестраивается геном, набор генов. Такие вирусы мутируют, и их патогенность возрастает. По этому поводу даже существует следующая гипотеза. ВИЧ зародился в Центральной Африке. Этот регион тоже эндемичен по селенодефициту. Нехватку Se испытывали животные, в том числе и обезьяны, инфицированные вирусом. В результате связанных с этим мутаций вирус приобрел антропогенные свойства - стал способен вызывать заболевание у человека.

Иммунологические нарушения могут пойти по другому типу, по аутоиммунному. В этом случае антитела-иммуноглобулины уничтожают собственные ткани. Так развивается ревматизм, ревматоидный артрит, системная красная волчанка, и другие диффузные заболевания соединительной ткани. Некоторые антитела повреждают ткань ЩЖ. Развивается аутоиммунный тиреоидит или болезнь Хашимито, также протекающая с явлениями гипотиреоза. Ухудшение антиоксидантной защиты, снижение иммунитета увеличивает частоту онкозаболеваний. Этому же способствует дисфункция печени и накопление в организме токсических соединений.

Негативные изменения претерпевает костно-мышечная система. В мышечной ткани развиваются дистрофические изменения, аналогичные таковым в миокарде. Снижается прочность костей, ухудшается работа суставов. Если селенодефицит появляется в детском или в юношеском возрасте, развивается болезнь Кашина - Бека. Данное заболевание сопровождается неправильным ростом и деформацией костей, суставов с множественными артрозами и мышечной дистрофией. Кожа при дефиците селена теряет свою эластичность, появляются ранние признаки старения в виде дряблости, морщин. Снижается устойчивость ее к действию солнечного ультрафиолета.

Нередко появляется гнойничковая сыпь, развиваются экзема, псориаз и другие виды дерматозов. Заживление кожи и слизи- 
стых после ран, ожогов, воспалительных процессов происходит очень медленно. Нехватка Se негативно сказывается на зрении, снижается его острота, в пожилом возрасте нередко возникает катаракта.

Самостоятельной специфической формой селеновой недостаточности является кешанская болезнь. В некоторых источниках ее называют болезнью Кешана, что не совсем верно. Кешан - это не ученый, изучивший и описавший болезнь. Название происходит от округа Кэшань на севере Китая, эндемичного по селенодефициту. В этой местности Se очень мало в почвах, и это приводит к тяжелым последствиям. Прежде всего страдает миокард. Снижается его сократимость, что приводит к компенсаторному утолщению, гипертрофии. На этом фоне развивается тромбоз сосудов, цирроз печени. Возникают патологические изменения в скелетных мышцах и в поджелудочной железе. Заболевание распространено не только в Северном Китае, но и в прилегающих регионах: в Приморье, Бурятии, Иркутской области. В основном болеют маленькие дети и молодые женщины. Кешанская болезнь протекает тяжело, с высокой летальностью. На вскрытии гипертрофированный миокард имеет неестественно светлый окрас, и по внешнему виду напоминает вареное мясо. Поэтому данное заболевание прозвали беломышкой (белая мышца).

Избыток Se сопровождается еще более разрушающими процессами, чем его недостаток. Ведь селен - яд, и оказывает благотворное действие лишь в микродозах. Считается, что верхним безопасным пределом для Se является суточная доза в пределах 400 мкг. Выраженные признаки интоксикации наблюдаются при поступлении 5 мг $\mathrm{Se}$ в сутки. Отравление может протекать остро или хронически. Следует заметить, что в естественных условиях избыток $\mathrm{Se}$ маловероятен, хотя и возможен. Дело в том, что некоторые растения концентрируют Se. Среди таковых солодка, хвощ полевой, донник, эвкалипт, а также астрагал, стенлея, галопаппус. Многие из них служат сырьем для селенсодер- 
жащих препаратов. Некоторые растения животные употребляют как корм. Сами по себе концентраторы Se при их умеренном потреблении не опасны. Опасность возникает, если они произрастают на почвах с высоким содержанием селена. Регионы, эндемичные по избытку селена, находятся на территории США, Канады, Австралии, Китая, а также в России, на Урале и в Якутии. В этом случае мясо животных, употребляющих в качестве корма растения, содержит избыток Se. В свою очередь человек перенасыщается микроэлементом при употреблении такого мяса. То же самое касается приема питьевой воды в таких регионах. Описаны случаи отравления Se человека и животных, связанные с нефтедобычей. При этом изначально содержание $\mathrm{Se}$ в почве не было повышено. Но затем из недр по нефтяным скважинам на поверхность изливалась вода, содержащая большое количество Se.

В плане избытка примечателен бразильский орех. Собственно говоря, по ботанической классификации это растение относится не к орехам, а к зерновым. Но суть не в этом. Зерна, похожие на орехи, являются кладезем многих микро- и макроэлементов, в том числе и селена. Одно зерно покрывает суточную потребность в Se. А однократный прием нескольких зерен сразу же приводит к острому отравлению.

Намного чаще отравление возникает при бесконтрольном приеме селенсодержащих средств с несоблюдением рекомендуемых доз. Были случаи непреднамеренной передозировки из-за ошибочных рекомендаций приема селенсодержащих биодобавок.

Характерный признак острой селеновой интоксикации чесночный запах, исходящий от кожи и изо рта. Еще один типичный симптом - ринорея, истечение слизи из носовых ходов или селеновый насморк. Пациенты жалуются на головную боль, тошноту, рвоту, боли в животе, понос. Появляются психические и неврологические расстройства различной степени тяжести. Первая помощь при отравлениях: внутривенное капельное вве- 
дение глюкозы и других плазмозамещающих растворов, а также введение натрия тиосульфата, являющегося антидотом (противоядием) для многих токсинов.

Хроническая интоксикация часто имеет производственный характер и связана с нефтепереработкой, металлургией, производством фармпрепаратов, пестицидов, лакокрасочных изделий. Население, проживающих в зонах промышленного загрязнения, тоже подвержено хроническим отравлениям. Селен в большом количестве инактивирует многие ферменты. Это пагубно отражается на состоянии систем органов. Развивается сосудистый атеросклероз. Возможны колебания АД в сторону повышения или снижения. Пациенты жалуются на общую слабость, снижение физической и умственной работоспособности. Возможны полинейропатии с ограничениями объема движений, ухудшением кожной чувствительности. Характерны множественные суставные воспаления (полиартриты). Страдает печень. Кожа приобретает желтушный оттенок, подвержена дерматитам. Из-за повышения проницаемости сосудов на ней возникает геморрагическая точечная сыпь. Типична анемия. Часто возникают простудные заболевания, осложняющиеся бронхопневмониями. Ногти размягчаются, расслаиваются. Зубная эмаль повреждается, и впоследствии зубы выпадают. Повышается опасность злокачественных новообразований. Первое, что нужно сделать, - это оградить организм от поступающего Se. Проводят комплексное лечение, направленное на восстановление пораженных органов.

\section{Участие в репродукции}

Селен участвует в развитии ооцитов и физиологии яичников. Пролиферация небольших первичных фолликулов (с меньшим количеством гранулезных клеток) до созревания преовуляторных фолликулов (со многими слоями клеток) является важным этапом фолликулогенеза. Se участвует в регуляции роста клеток гранулезы и биосинтеза $17 \beta$-эстрадиола в яичниках. 
Уровни $\mathrm{Se}$ и СП выше в больших здоровых фолликулах и могут выполнять жизненно важную антиоксидантную функцию во время более позднего роста и пролиферации фолликулов. Кроме того, выраженный дефицит Se наблюдается при бесплодии как женщин, так и мужчин. Считается, что антиоксидантная активность селеноферментного белка в микроокружении фолликулов играет значительную роль в гаметогенезе и оплодотворении.

\section{Акушерские и перинатальные результаты дефицитных состояний}

Считается, что уровень селена до беременности имеет особое значение в отношении риска формирования гестационных гипертонических состояний, чем его содержание во время беременности. С одной стороны, именно преконцепционный период определяет качество ооцитов и последующие за зачатием процессы имплантации. С другой - потенциально опасные дефициты могут воздействовать и на процессы инвазии цитотрофобласта, оказав тем самым влияние на формировании плацентарной недостаточности и, соответственно, на риск развития поздних осложнений гестации.

Низкий уровень Se ассоциируется с риском невынашивания беременности. Даже во время неосложненной гестации концентрации Se в цельной крови значительно падают. Вероятно, это связано с увеличением объема плазмы во II и III триместрах, а также трансплацентарным переносом селена посредством СП SELENOP, который экспрессируется в тканях плаценты. И, наоборот, более высокий уровень Se в сыворотке крови был связан с более низким риском выкидышей и преждевременных родов. Это связано со способностью $\mathrm{Se}$ подавлять окислительный стресс, эндотелиоз, регулировать выработку эйкозаноидов, модулировать тонус сосудов и оказывать противовоспалительное действие. 
Дефицит Se наблюдается и при осложнениях беременности, таких как привычное невынашивание, ПР, ЗРП, а также послеродовая дисфункция ЩЖ. В некоторых рандомизированных контролируемых исследованиях и обсервационных исследованиях есть доказательства того, что Se (вероятно, как компонент селенопротеинов) может снижать уровни антител к пероксидазе ЩЖ, вызывая гипотиреоз и заболевания ЩЖ после родов. Беременные женщины с дефицитом селена, имеющие высокий уровень антител к пероксидазе щитовидной железы, имеют более высокий риск развития послеродового гипотиреоза. Se также участвует в снижении воспалительной активности ЩЖ у пациенток с аутоиммунным тиреоидитом. Как известно, дисфункция ЩЖ и развитие гипотиреоза нередко наблюдаются у соматически здоровых женщин во время беременности, что является физиологически обоснованными, учитывая потребности плода в тиреоидных гормонах, а затем и сочетанное влияние и гормонов ЩЖ плода. С другой стороны, гипотиреоз может являться причиной невынашивания беременности, соответственно дотация Se на ранних сроках гестации, возможно, позволит снизить риск развития этого осложнения. Однако в доступной литературе мы не нашли публикаций, посвященных изучению связи дефицита Se и гипотиреоза у пациенток с невынашиванием.

\section{Способы лабораторной диагностики}

Исследование сыворотки или плазмы достаточно точно отражает статус Se в организме и адекватность его недавнего приёма (при условии знания изменений на фоне острофазного ответа). Исследование проводится методом масс-спектрометрии с индуктивно связанной плазмой. Референсные значения составляют $0,07-0,12$ мкг/мл.

Также субстратами для проведения исследования могут быть волосы, ногти и моча. Для оценки уровня токсичности селена целесообразно исследовать 24-часовую мочу. Концентра- 
ция селена в ней, в зависимости от географического источника потребляемой пищи, может колебаться от 20 до 1000 мкг/л. Исследования $\mathrm{Se}$ в волосах целесообразно использовать для оценки долговременного потребления Se. Стоит отметить, что лечебные шампуни и другие средства для ухода за волосами могут содержать Se и вызывать внешнее загрязнение пробы.

\section{Варианты коррекции}

Рост числа заболеваний, связанных с селенодефицитом, побудил правительства многих стран разработать соответствующие программы по селенизации населения. Особенно поучителен в этом плане опыт Финляндии. В этой стране почвы тоже бедны Se. Благодаря проведенным мероприятиям в Финляндии заметно снизилось количество сердечно-сосудистых, онкологических и эндокринных расстройств. В 1998 г. правительство РФ издало постановление № 917 «О неотложном обеспечении населения селеном в числе других витаминов и минералов». В последующие годы были изданы другие нормативные акты по селенизации. Согласно этим документам селенизация предусматривает: включение в пищевой рацион натуральных продуктов, богатых селеном, включение Se в состав почвенных удобрений, обогащение $\mathrm{Se}$ хлебобулочных изделий и других продуктов питания, прием Se в составе биодобавок с профилактической целью. В биодобавках $\mathrm{Se}$ часто сочетается с другими нутриентами.

В качестве примеров можно привести «Селен-Актив» (с витамином C), «Триовит» (с производными витаминов А, C, Е).

Существуют препараты Se с цинком, йодом. Вообще, все селенсодержащие средства можно разделить на четыре группы:

1. Неорганический Se. B основном это натрия селенит. На его основе создана даже инъекционная форма, «Селеназа». Раствор «Селеназы» предназначен для внутримышечного и внутривенного введения. Правда, неорганический селен плохо всасы- 
вается и точно так же плохо переносится. Очень часто возникают побочные эффекты в виде тошноты и болей в животе. При бесконтрольном приеме препарат накапливается в организме в виде токсичных форм.

2. Дрожжевой Se. Благодаря комбинации с дрожжевым грибком удается получить 20-30 \% органического Se. Остальное количество представлено неорганической формой.

3. Органический Se. Здесь микроэлемент связывается с так называемым биолигандом, белком-носителем. Эта форма усваивается и переносится намного лучше.

4. Селен-метионин. Комплекс Se с метионином - оптимальная, физиологичная форма. Именно в такой форме микроэлемент включен в состав селенопротеинов.

Взаимодействие с другими веществами. Сочетание с витаминами Е, С характеризуется взаимным усилением активности. $\mathrm{Se}$ позитивно влияет на усваивание витаминов А, К. Стимулирует эффекты, оказываемые йодом, цинком. Находится в антагонизме с тяжелыми металлами (свинцом, таллием, кадмием, ртутью), а также с медью и серебром. Усиленное поступление в организме этих элементов приводит к снижению уровня Se. То же самое касается сульфатов, углеводов, ПНЖК (полиненасыщенных жирных кислот), этилового спирта.

Ряд препаратов (оральные контрацептивы, противовоспалительные, слабительные средства, статины, анаболики, энтеросорбенты) тоже негативно влияют на баланс этого микроэлемента. В свою очередь Se ухудшает усваивание никеля. 


\section{йод}

Йод (лат. Iodum, I) химически активный неметалл, относится к группе галогенов. Впервые йод был получен в 1811 г. французом Куртуа. Это был химик, а также владелец селитроварни. Соду для изготовления селитры он получал из золы морских водорослей. Когда Куртуа добавил к рассолу от золы концентрированную серную кислоту, началась реакция с выделением фиолетовых паров, запахом, напоминающим хлор. Это были пары йода. Правда, молва приписывает открытие не самому Куртуа, а его коту. Якобы животное случайно опрокинуло сосуд с кислотой на зольный рассол. В 1813-1814 гг. французский и английский химики Гей-Люссак и Дэви идентифицировали новый элемент и назвали его йодом от греческого «йоэйдес», фиолетовый. Буквально сразу же после открытия, в 20-х гг. $\mathrm{XIX}$ в. были изучены полезные свойства йода как лекарственного средства в лечении заболеваний ЩЖ.

Примечательно, что вплоть до середины прошлого века вещество называли йодом, и в таблице Менделеева обозначали буквой J, Jodum. Затем элемент решили обозначать как йод, а букву J заменили на I. Однако и в русском языке, и в некоторых европейских языках наряду с общепринятым термином продолжают использовать старый. Название «йод» употребляют в разговорной речи, а также для обозначения медицинских препаратов, биологических процессов.

В периодической системе элементов Менделеева йод располагается в VII группе 5-го периода под № 53. Его атомная масса равна 127. Примечательно, что когда-то она равнялась 129 за счет более тяжелого радиоактивного изотопа. Однако за миллиарды лет этот нестабильный изотоп практически весь распался, и его почти не осталось. VII группу еще называют галогенами. Помимо йода в группу галогенов входят фтор, бром, хлор, 
а также астат. Отличительная особенность галогенов: у них на внешней орбите вращаются семь электронов, и до полного завершения не хватает одного электрона. Этот электрон они присоединяют от атомов других элементов при взаимодействии с ними. Поэтому галогены, как правило, одновалентны и являются сильными окислителями. Но чем больше размер атома, тем слабее окислительная способность. Поэтому у йода она ниже, чем у многих других галогенов - фтора, хлора и брома.

Тем не менее йод - довольно активный химический элемент. Он реагирует со щелочами, некоторыми кислотами, а также с металлами и неметаллами, в том числе и со своими «родственниками» галогенами. В большинстве случаев валентность йода равна 1. Однако при определенных условиях она может составлять $3,5,7$. С водородом и кислородом йод участвует в образовании кислот: йодной, йодистой, йодоводородной, йодноватой, йодноватистой.

Он плохо растворяется в воде и хорошо в спирте, эфире, бензоле и других органических растворителях. Характерна реакция йода с крахмалом, протекающая с окрашиванием в синий цвет. В связи с этим йод можно рассматривать как индикатор крахмала. Молекула йода образована двумя атомами, $\mathrm{I}_{2}$. Внешне это темно-серые с фиолетовым блеском кристаллы. Плотность

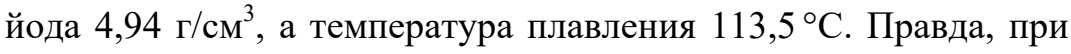
обычном давлении и медленном нагревании твердый йод сразу же переходит в газообразное состояние, минуя жидкое. При этом образуются фиолетовые пары со специфическим запахом. Однако в природе йод из-за высокой химической активности в свободном виде не встречается, а лишь в виде соединений. В целом содержание йода в земной коре невелико, всего лишь $4 \cdot 10^{-5} \%$. По этому показателю он занимает 60 -е место среди всех элементов таблицы Менделеева. Однако соединения йода, йодиды, несмотря на малое количество, распространены повсеместно. Они растворены в морской воде, а также в глубоких водах, изливающихся на поверхность из термальных источников 
и нефтяных скважин. В одной тонне морской воды содержится около 20-30 мг йода. Многие морские организмы, водоросли обладают уникальной способностью извлекать этот элемент из воды, превращать его в усваиваемую форму и накапливать в собственных тканях.

\section{Основы метаболизма}

Всасывание йода происходит в верхних отделах тонкого кишечника, куда он поступает в виде органических и неорганических соединений - йодидов, йодированных аминокислот и жирных кислот. Большая часть всосавшегося йода связывается со специфическим белком-переносчиком, и в таком виде разносится по органам и тканям. При этом он поступает в печень, в почки, в яичники у женщин и в предстательную железу у мужчин.

Определенное количество микроэлемента поглощается кожей и ее придатками, волосами и ногтями. Но основным потребителем йода является, конечно же, ЩЖ. Функциональная ткань этой железы состоит из множества мельчайших пузырьков - фолликулов. Фолликулы изнутри выстланы клетками-тиреоцитами и заполнены коллоидом. Эта вязкая субстанция содержит белкитиреоглобулины, которые поступают сюда из тиреоцитов.

В образовании тиреоглобулинов участвует аминокислота L-тирозин. Тиреоглобулины - это сырье для образования трийодтиронина и тироксина. Йод вначале поступает из крови в тиреоциты, а затем - в коллоид. Здесь при участии железа и специфического фермента тиреоидной пероксидазы происходит последовательное йодирование, присоединение атомов йода к молекуле тиреоглобулина. Присоединяется одна молекула образуется монойодтиронин, две - дийодтиронин. Правда, эти вещества не активны. Но с дальнейшим присоединением йода образуются трийодтиронин, или $\mathrm{T}_{3}$, и тироксин, или $\mathrm{T}_{4}$. Эти вещества уже обладают гормональной активностью. Правда эта 
активность, как и их содержание, неодинакова. Содержание $\mathrm{T}_{4}$ в несколько раз больше, чем $\mathrm{T}_{3}$. Зато $\mathrm{T}_{3}$ более активен, чем $\mathrm{T}_{4}$.

Установлено, что $\mathrm{T}_{3}$ образуется из $\mathrm{T}_{4}$ в ходе дейодирования, отщепления молекулы йода. Щитовидные гормоны, тироксин и трийодтиронин, выбрасываются в кровь. В плазме крови они связываются другим переносчиком, тироксинсвязывающим глобулином и в таком виде разносятся по органам и тканям. Выполнив свою функцию, они частично разрушаются, а частично выводятся в неизмененном виде. Свободный йод и йод в составе тиреоидных гормонов покидает наш организм в основном с мочой, и в меньшей степени - с калом.

Определенное количество йода выводится со слюной и с потом. Примечательно, что по выведению йода с мочой (йодурии) можно судить о наличии йода в организме. Чем больше йода поступает в организм, тем больше его выводится с мочой, и наоборот. Поэтому низкая йодурия свидетельствует о нехватке йода. И по той же причине определение йода в моче используют для выявления йододефицитных состояний.

\section{Физиологические функции}

В организме человека йод содержится в микродозах, не более 20-25 мг. Из этого общего количества значительная часть йода, около 15 мг, находится в ЩЖ, которая, будучи органом эндокринной системы, влияет практически на все физиологические процессы. Это влияние она оказывает посредством вырабатываемых ею тиреоидных гормонов: тиреокальцитонина, трийодтиронина и тироксина. Тиреокальцитонин, или кальцитонин, обеспечивает обмен кальция и фосфора, способствует их отложению в костях. Но здесь заслуги йода нет данный микроэлемент не входит в состав кальцитонина. А вот два других гормона, трийодтиронин и тироксин, содержат в своей структуре йод. 
В молекуле трийодтиронинна содержится три молекулы йода. Поэтому его принято обозначать $\mathrm{T}_{3}$. В тироксине, который еще называют тетрайодтирониом, четыре молекулы йода, и его обозначают как $\mathrm{T}_{4}$. Таким образом, йод служит строительным элементом для тироксина и трийодтиронина, и без него синтез этих гормонов невозможен. ТГ и, соответственно, йод оказывают многообразное влияние на обменные процессы, на состояние и функцию тканей и органов. Это влияние характеризуется ускорением обменных процессов и катаболизмом, распадом белков, жиров и гликогена. В итоге выделяется энергия, которая затрачивается на нужды организма. Потребность в энергии увеличивается при стрессовых ситуациях: физических и умственных нагрузках, переохлаждении, негативных эмоциях, инфекционных и неинфекционных (соматических) заболеваниях, перенесенных заболеваниях и травмах, избегании ситуаций, связанных с грозящей опасностью. И здесь на помощь приходит йод в составе ТГ.

Катаболизм белка (протеолиз) в скелетных мышцах повышает силу мышечных сокращений, обеспечивает выносливость при выполнении физической работы. Под действием тиреоидных гормонов происходит не только распад белков, но и их образование. Белковый синтез обеспечивает РНК. В свою очередь в образовании РНК наряду с другими факторами участвуют ТГ. Синтез белков в сочетании с ускорением обменных процессов приводит к тому, что поврежденные в результате травм и воспалительных процессов ткани быстрее восстанавливаются. Помимо белка мышцы содержат гликоген. Это своего рода углеводный полимер, состоящий из звеньев-мономеров, глюкозы. Расщепление гликогена (гликогенолиз) в мышцах также сопровождается выделением энергии, которая затрачивается на выполнение физической работы.

Однако большая часть гликогена содержится в печени. Этот орган является депо, своего род складом, для гликогена. Отсюда гликоген расходуется по мере необходимости. Расщеп- 
ление печеночного гликогена под действием тиреоидных гормонов сопровождается выходом в кровь глюкозы. Таким образом, йод поддерживает на должном уровне гликемию (уровень глюкозы в крови). В дальнейшем глюкоза из плазмы крови транспортируется внутрь клетки, где и сгорает в цикле биохимических реакций (цикле Кребса) с образованием энергии в виде молекул АТФ. Не только физическую, но и умственную активность повышают тиреоидные гормоны. Ведь некоторое количество гликогена содержится в ЦНС - в головном мозге.

Кроме того, щитовидные гормоны улучшают проведение импульсов по нервным волокнам. Благодаря этому улучшается мышление, концентрируется внимание. Тиреоидные гормоны наряду с другими факторами обеспечивают восприятие и запоминание поступившей информации. Еще больше энергии образуется при расщеплении жиров (липолизе). В этом плане содержащие йод щитовидные гормоны следует рассматривать как сжигатели жира. Это они препятствуют появлению жировых отложений под кожей, предотвращают ожирение и нормализуют массу тела. Поэтому йод иногда называют микроэлементом стройности.

Распад жиров сопровождается выделением тепла. Теплопродукция играет решающую роль в поддержании температуры тела в физиологических пределах и в предотвращении переохлаждения. Расщепляя жиры, тиреоидные гормоны уменьшают количество низкоплотного холестерина. Это один из липидов (жироподобных веществ). Холестерин низкой плотности идет на построение атеросклеротических бляшек. Таким образом, тиреоидные гормоны предотвращают развитие атеросклероза и связанных с ним состояний, прежде всего, инфаркта миокард и инсульта. Кроме того, ТГ регулируют АД. Но эта регуляция неоднозначна. Как и в скелетных мышцах, в миокарде ускоряются обменные процессы. В итоге возрастают сила и частота сокращений сердца. С одной стороны, улучшается тканевое кровоснабжение и доставка кислорода, предотвращается за- 
стойная сердечная недостаточность и гипоксия. С другой стороны, увеличивается систолическое АД. Однако ТГ расширяют сосудистый просвет и дополнительно улучшают кровообращение. При этом диастолическое АД снижается.

Под действием ТГ ускоряется образование эритроцитов в красном костном мозге. Это дополнительно улучшает тканевой транспорт кислорода. Образование не только эритроцитов, но и лейкоцитов стимулируют ТГ. Под их действием повышается фагоцитарная активность лейкоцитов, усиливается продукция антител. Организм становится устойчивым к действию патогенных (болезнетворных) бактерий, грибков, вирусов.

Не только сердечно-сосудистую и иммунную, но и пищеварительную систему стимулирует йод. Под влиянием ТГ усиливается перистальтика гладкой мускулатуры ЖКТ. Эти же гормоны стимулируют выделение пищеварительных соков. В итоге пища быстрее продвигается и лучше переваривается. Микроэлемент улучшает пищеварительную и детоксикационную функцию печени. Установлено, что под действием щитовидных гормонов нейтрализуются соли тяжелых металлов и некоторые другие токсины.

Наряду с другими органами йод улучшает кровообращение в почках и стимулирует выделение мочи. ТГ регулируют баланс натрия и препятствуют задержке жидкости в организме, предупреждают появление отеков.

Примечательно, что йод действует не только в составе щитовидных гормонов, но и в составе некоторых других белков в органах и тканях. Так, йод повышает прочность и эластичность кожи, замедляет процессы кожного старения. Микроэлемент стимулирует рост волос, препятствует их выпадению и улучшает остроту зрения.

Действие йода не ограничивается одной лишь ЩЖ. Она находится в прямом подчинении от мозговых структур, гипофиза и гипоталамуса. Но и сама железа по принципу обратной связи регулирует функцию гипоталамо-гипофизарной системы. 
Косвенно ЩЖ влияет на функцию надпочечников. ТГ повышают уровень адреналина.

Тиреоидные гормоны прямо или опосредованно улучшают усваивание многих витаминов, в частности витаминов E, D, A, некоторых витаминов группы В.

Более всего выражено влияние ТГ на функцию мужской и женской репродуктивной систем. Под их влиянием в печени синтезируется холестерин высокой плотности. Этот же холестерин служит сырьем для гормонов-стероидов. Стероидную структуру имеют гормоны коры надпочечников, мужские (тестостерон) и женские (эстрогены, прогестерон) половые гормоны. Таким образом, ЩЖ посредством трийодтиронина и тироксина обеспечивает половое созревание, формирование первичных и вторичных половых признаков, образование полноценной, способной к оплодотворению спермы у мужчин, созревание фолликулов и овуляцию при нормальном менструальном цикле у женщин. Без йода невозможно зачатие. Точно так же невозможно нормальное течение беременности. Микроэлемент участвует в эмбриогенезе. Особенно велика его роль в развитии головного мозга плода. После рождения йод вместе с другими витаминами и минералами обеспечивает полноценную лактацию. В дальнейшем йод в составе ТГ отвечает за правильное физическое и психическое развитие.

\section{Содержание в продуктах, суточные нормативы потребления}

Потребность в йоде составляет от 2 до 4 мкг на 1 кг массы тела. Рекомендуемая суточная норма потребления представлена в табл. 12.

Потребность в йоде повышается при стрессовых ситуациях (физических нагрузках, заболеваниях), приеме препаратов, угнетающих функцию щитовидной железы. Среди этих препаратов: 
НПВС, глюкокортикоиды, интерфероны, бета-адреноблокаторы, гепарин, соли лития, специфические средства, назначаемые при гипертиреозе (тиамазол, мерказолил, пропилтиоурацил).

Таблица 12

\section{Суточное потребление йода}

\begin{tabular}{|l|c|}
\hline \multicolumn{1}{|c|}{ Категория } & Суточная норма, мкг \\
\hline Дети до 2 лет & 50 \\
\hline Дети 3-5 лет & $60-90$ \\
\hline Дети 6-8 лет & $90-120$ \\
\hline Дети 9-13 & 120 \\
\hline Подростки-юноши & 150 \\
\hline Подростки-девушки & 150 \\
\hline Взрослые мужчины & 180 \\
\hline Взрослые женщины & 150 \\
\hline Беременные и кормящие женщины & $200-250$ \\
\hline
\end{tabular}

При этом потребность в микроэлементе может достигать 400 мкг. Однако суточное поступление йода не должно превышать токсический порог 500 мкг.

До $60 \%$ йода поступает к нам в составе животных продуктов, до $30 \%$ - растительных, а остальное - с водой. Некоторое количество микроэлемента мы получаем в составе вдыхаемого воздуха. Общепризнанные лидеры по содержанию йода рыба и морепродукты. Содержание йода в 100 г продуктов представлено в табл. 13.

Таблица 13

\section{Содержание йода в продуктах питания}

\begin{tabular}{|l|c|}
\hline \multicolumn{1}{|c|}{ Продукт } & Содержание, мг/100 г \\
\hline Сушеная ламинария (морская капуста) & $2500-3000$ \\
\hline Приготовленная морская капуста & 300 \\
\hline Кальмары & 290 \\
\hline Креветки, крабы, устрицы & $90-100$ \\
\hline Мясо ластоногих & 130 \\
\hline Треска, путассу & 130 \\
\hline
\end{tabular}


Окончание табл. 13

\begin{tabular}{|l|c|}
\hline \multicolumn{1}{|c|}{ Продукт } & Содержание, мг/100 г \\
\hline Лосось & 200 \\
\hline Минтай, хек & $150-160$ \\
\hline Окунь, судак, сом, щука, камбала, судак, мойва & 50 \\
\hline Анчоусы, скумбрия & 45 \\
\hline Мидии & 190 \\
\hline Шампиньоны & 18 \\
\hline Яичный желток & 35 \\
\hline Молоко и кисломолочные продукты & $8-18$ \\
\hline Бобовые, овощи, свежая зелень & $6-15$ \\
\hline Ягоды, фрукты, злаки & $2-10$ \\
\hline Кедровые орехи & 400 \\
\hline Твердые сорта сыра & 11 \\
\hline
\end{tabular}

Основная причина - алиментарный фактор, недостаточное поступление йода с пищей из-за низкого содержания в почве и воде. Ведь в целом он находится в земной коре в малом количестве. Но и это количество распределено неравномерно. Довольно много йода растворено в водах морей и океанов. Поэтому жители прибрежных зон практически никогда не страдают от его нехватки - микроэлемент поступает не только с пищей, но и с вдыхаемым морским воздухом. Но чем дальше от берега вглубь материка и выше в горы, тем йододефицит ощущается острее.

Больше всего йода в рыбе и в морепродуктах. Поэтому игнорирование этих продуктов, вегетарианство приводят к недостаточному поступлению йода.

Оптимальной суточной потребностью взрослого человека в йоде считается его уровень в 150 мкг/сут (для детей 50-100 мкг/сут), что обеспечивает необходимый синтез ТГ. Во время беременности и лактации потребление йода должно составлять 250 мкг/сут (согласно ВО3). 


\section{Эпидемиология}

Йододефицитные заболевания (ЙДЗ) - это все патологические состояния, развивающиеся в популяции в результате йодного дефицита (ЙД), которые могут быть предотвращены нормальным потреблением йода (согласно данным ВОЗ). ЙД является важной медико-социальной проблемой, поскольку его наличие доказано практически на всей территории России и во многих регионах мира. ЙД диагностируется практически у $70 \%$ беременных женщин на территории России.

Практически на всей территории России реальное потребление йода составляет не более 40 - 80 мкг в день, что соответствует как минимум умеренному дефициту йода или средней тяжести ЙД. Умеренный дефицит йода наиболее четко охарактеризован как «скрытый голод». Распространенность клинически манифестного гипотиреоза, который является крайним проявлением йодной недостаточности, в регионах с умеренным йодным дефицитом может не превышать таковую в регионах с нормальным обеспечением йодом. Тем не менее показатели умственного развития населения (IQ-индекс), проживающего в регионах йодной недостаточности, достоверно (на 15-20 \%) ниже таковых в регионах без ЙД. Наиболее вероятной причиной этого является неблагоприятное воздействие даже умеренного ЙД в период формирования центральной нервной системы, в первую очередь во время беременности и в перинатальном периоде. Беременность является наиболее мощным фактором, потенцирующим влияние дефицита йода как на организм матери, так и плода, или, по словам D. Glinoer, является пусковым фактором йодного «обкрадывания» и приводит к состоянию относительного дефицита йода. 


\section{Симптомы дефицита и избытка}

О ЙД говорят в тех случаях, если его суточное поступление с пищей не превышает 10 мкг.

При хронических заболеваниях ЖКТ ухудшается всасывание многих пищевых компонентов, и йод - не исключение. Курение, злоупотребление алкоголем, прием препаратов (антибиотики, противовоспалительные, жаропонижающие, некоторые антиаритмические) - все это тоже негативно влияет на баланс йода.

Некоторые состояния сопровождаются усиленным расходом йода:

- физические нагрузки,

- перенесенные острые заболевания и травмы,

- хронические заболевания,

- беременность,

- периоды быстрого роста у подростков, половое созревание,

- другие виды стрессовых нагрузок.

В этих случаях формируется относительная недостаточность йода. Такое состояние со сниженной гормонпродуцирующей функцией ЩЖ называют гипотиреозом. Стремясь извлечь максимальную пользу из имеющегося йода, и хоть в какой-то мере увеличить производство тиреоидных гормонов, железа увеличивается в размерах. Такое увеличение называют зобом. Следует заметить, что это не самостоятельная патология. Понятие «зоб»- собирательное. Оно подразумевает любое увеличение размеров железы. Увеличение может происходить равномерно (диффузный зоб) и в виде очагов (узловой зоб). При этом ее гормонпродуцирующая функция тоже может существенно различаться. Иногда компенсаторное увеличение ЩЖ дает результат, и на фоне ЙД уровень ТГ все-таки приходит в норму. Такой зоб называют эутиреоидным. Однако во многих случаях, несмотря на увеличение размеров, гипотиреоз сохраняется. Сам по себе зоб - это уже физический и психический дискомфорт. 
Кроме того, при значительной степени увеличения создается механическое препятствие дыханию, что приводит к одышке.

Женщины в большей степени подвержены недостатку йода. Причина в том, что железа функционально связана с яичниками и реагирует на циклические колебания женских половых гормонов. Недостаток йода и гипотиреоз приводят к замедлению обменных процессов в организме. За счет отложения жира увеличивается масса тела. Ожирение, в свою очередь, приводит к сахарному диабету 2-го типа, обусловленному относительной нехваткой инсулина. Негативные изменения претерпевает сердечно-сосудистая система. Снижается сила сокращений миокарда, появляется брадикардия, замедление частоты сокращений сердца менее 60 уд./мин. Формируется застойная сердечная недостаточность, прогрессирует сосудистый атеросклероз.

Пациенты с гипотиреозом имеют характерный внешний вид. Замедление выделения жидкости приводит к отекам конечностей и лица, которое становится одутловатым. Кожа становится сухой и бледной, волосы ломкими. Этот комплекс внешних изменений при гипотиреозе именуют микседемой. Для таких пациентов характерна анемия. Температура тела снижена, из-за чего они жалуются на озноб. Ухудшается процесс пищеварения. Появляется вздутие живота, метеоризм, запоры. Сами пациенты вялы, адинамичны. Отмечается замедленное мышление, плохая память, невнимательность. У женщин нарушается менструальный цикл и возможно бесплодие.

Сам по себе йод токсичен. Отравление возможно при систематическом поступлении йода в организм и его накоплении, кумуляции или же при разовом поступлении больших доз микроэлемента. Даже при ежедневном потреблении йодсодержащих морепродуктов хроническое отравление йодом вряд ли произойдет. А вот при бесконтрольной передозировке йодсодержащих средств это возможно. Еще одна причина - ингаляционное поступление паров йода на вредных производствах. Йодная интоксикация проявляется йодизмом. Это комплекс симптомов 
неинфекционного воспаления кожи и слизистых оболочек. Поражение глаз принимает характер конъюнктивита, склерита со слезотечением и резью в глазах. Пациенты жалуются на металлический привкус во рту, слюнотечение, першение в горле, кашель и осиплость голоса. Типичны трахеобронхиты, которые из-за слабого иммунитета часто принимают инфекционный характер. Поражение ЖКТ характеризуется болями в животе, нарушением печеночных функций, поносами с примесью крови. Йододерма - это поражение кожи при йодной интоксикации, проявляется высыпаниями с преимущественной локализацией на коже верхней части тела, лица, рук, шеи, ушных раковин. Высыпания многообразны и могут принимать характер пузырьков, узелков, больших пузырей с жидким содержимым, изъязвлений, эрозий. У некоторых йододерма проявляется крапивницей, распространяющейся по всему телу и сопровождающейся зудом. Данные симптомы обусловлены тем, что йод в больших количествах фиксируется тканями и разрушает тканевые белки.

Избыток йода отражается на гормонпродуцирующей функции ЩЖ. Возрастает количество ТГ - развивается гипертиреоз. Данное состояние тоже сопровождается диффузным увеличением щитовидной железы. Для данного состояния характерна повышенная возбудимость, немотивированная тревога, бессонница. Появляется потливость, сердцебиение, зачастую - нарушения сердечного ритма. Характерен внешний вид таких пациентов: исхудание, тремор и экзофтальм. Женщины, как и при гипотиреозе, часто страдают нарушениями менструального цикла, бесплодием, возможны акушерские осложнения. В дальнейшем развивается обратный эффект - при чрезмерном поступлении йода продукция ТГ снижается, развивается гипотиреоз.

Разовое поступление йода в большом количестве, свыше 500-600 мкг, приводит к острому отравлению с тяжелейшими последствиями, иногда несовместимыми с жизнью. Появляется неукротимая рвота, боли в животе, диарея, кожа и слизистая полости рта окрашиваются в коричневый цвет. Сознание частично 
или полностью утрачивается, возможны судороги. Смерть наступает от паралича дыхания и остановки сердца.

При первых же признаках отравления следует прекратить поступление йода в организм. Пища, богатая этим микроэлементом, тоже исключается. Проводят детоксикационное и симптоматическое лечение. Натрия тиосульфат - антидот (противоядие) при многих отравлениях, в том числе и при отравлениях йодом. Еще большую опасность для человека представляет радиоактивный изотоп йода, йод-131. Он не встречается в природе, а образуется искусственно в результате деления ядер урана, плутония при ядерных взрывах и реакциях на АЭС и загрязняет окружающую среду. Особенно много йод-131 выделилось после аварии на Чернобыльской АЭС. Опасность йод-131 заключается в том, что он также накапливается ЩЖ. При этом он вытесняет обычный, стабильный йод и провоцирует развитие рака ЩЖ. Также йод-131 используют в лечебных целях при раке ЩЖ. Радиоактивный йод проникает в раковые клетки железы и уничтожает их. Пребывание в зонах, загрязненных радиоактивным йодом, требует приема йодсодержащих препаратов и йодированной соли. Содержащийся в них стабильный йод вытесняет из ЩЖ радиоактивный изотоп.

\section{Участие в репродукции}

Йод принадлежит к жизненно важным микроэлементам, без которых невозможно нормальное функционирование человеческого организма.

Биологическое значение йода состоит в том, что он является структурным компонентом гормонов ЩЖ, которые определяют активность течения практически всех метаболических процессов в организме. ТГ играют важную роль в жизнедеятельности человека любого возраста, но особенно в период внутриутробной и ранней постнатальной жизни. 
Именно на этих этапах гормоны ЩЖ оказывают влияние на дифференцировку тканей, прежде всего нервной, сердечнососудистой и опорно-двигательной системы; определяют развитие мозговых структур и нервной системы плода; становление и поддержание интеллекта в течение всей жизни.

Роль ТГ в процессах становления и регулирования репродуктивной системы у женщин играет огромную роль. В физиологических условиях ТГ поддерживают нормальную продукцию пролактина, активность желтого тела и тем самым нормальный уровень функционирования системы репродукции. В пубертатный период ТГ совместно с половыми стероидами активизируют завершение физической, половой и психической дифференцировки и способствуют установлению в женском организме нормального двухфазного менструального цикла. Гормоны ЩЖ стимулируют функцию желтого тела, что важно для поддержания беременности на ранних сроках. Заболевания ЩЖ с нарушением ее функции негативно влияют на процесс имплантации плодного яйца и приводят к формированию первичной плацентарной недостаточности. Гормоны ЩЖ матери играют важную роль на протяжении всего гестационного периода.

Йод необходим для правильного функционирования ЩЖ. В случае некорригированнного ЙД на этапе прегравидарной подготовки, при беременности развивается патологическая дисфункция ЩЖ. Мозг плода очень чувствителен к дефициту йода, и поскольку основная часть формирования головного мозга плода происходит на ранних сроках беременности, дефицит йода в начале беременности увеличивает риск задержки развития нервной системы у ребенка. Это подчеркивает важность обеспечения адекватного йодного питания женщин репродуктивного возраста. 


\section{Акушерские и перинатальные результаты дефицитарных состояний}

Во время беременности в организме женщины вырабатываются специфические гормоны и гормоноподобные вещества, которые оказывают влияние на метаболизм ТГ. К таким факторам относят: хорионический гонадотропин человека (ХГЧ), повышение продукции эстрогенов и тироксинсвязывающего глобулина, увеличение почечного кровотока и клубочковой фильтрации, которое приводит к усилению экскреции йода с мочой. ХГЧ, обладая тиреотропным действием, вызывает гипертрофию и гиперстимуляцию ЩЖ во время беременности, и, как следствие, повышенный уровень тироксина по механизму отрицательной обратной связи приводит к снижению ТТГ. Так, повышение уровня ХГЧ на $10000 \mathrm{ME} / л$ увеличивает уровень свободного тироксина на 0,6 ммоль/л и подавляет базальный уровень ТТГ на 0,1 мЕд/л.

Также косвенным стимулятором ЩЖ во время беременности является возрастающая выработка эстрадиола, который, в свою очередь, стимулирует синтез тироксинсвязывающего глобулина. Увеличение продукции этого гликопротеина приводит к транзиторному снижению свободных, биологически активных фракций, что ведет к дополнительной стимуляции ЩЖ.

На протяжении всего периода гестации наблюдается увеличение объема почечного кровотока и скорости клубочковой фильтрации, что вызывает повышение почечного клиренса йода и усугубление дефицита йода во время беременности.

Особое значение для состояния ЩЖ во время беременности имеет функционирование системы фетоплацентарного комплекса. До полноценного формирования и функционирования ЩЖ у плода повышенная потребность в ТГ обеспечивается гиперстимуляцией ЩЖ посредством высокого уровня ХГЧ. Плод при этом частично снабжается ТГ матери, проникающими трансплацентарно. Антенатальная закладка ЩЖ у плода происходит на 4-5-й неделе, на 10-12-й неделе она приобрета- 
ет способность накапливать йод и синтезировать йодтиронины, к 17-18-й неделе ЩЖ плода уже дифференцирована и полноценно функционирует.

Плацента является частично проницаемой для ТГ, а тироксин определяется в околоплодных водах еще до того, как начинает работать ЩЖ плод. Через плацентарный барьер способны проникать йод, тиреотропин-рилизинг-гормон, тиреостатики и антитела. Доказательством частичной проницаемости плаценты для ТГ является нормальный или завершенный органогенез у плода при врожденном гипотиреозе, обусловленном дефицитом тиреопероксидазы, при котором невозможен адекватный синтез ТГ у плода. Помимо этого, ТГ определяются в амниотической жидкости уже к окончанию I триместра, когда щитовидная железа плода еще не выполняет в полном объеме своих функций. Особое значение в обмене йодтиронинов и йода между организмом матери и плодом имеют плацентарные дейодиназы. В плаценте содержится дейодиназа 3-го типа, которая осуществляет метаболизм тироксина в реверсивный трийодтиронин, а трийодтиронин - в дийодтирозин, т.е. превращение тиреоидных гормонов в биологически неактивные субстраты. Одной из основных функцией дейодиназы 3-го типа является уменьшение содержания трийодтиронина и тироксина в сыворотке плода (уровень последнего на момент родов составляет у плода около $50 \%$ от уровня такового у матери), а также дополнительную дотацию йода, за счет дейодирования йодтиронинов беременной. В условиях дефицита йода дейодирование тиреоидных гормонов беременной за счет выраженного увеличения активности дейодиназы 3-го типа является фактором, обеспечивающим плод йодом. С этой целью фетоплацентарным комплексом могут быть использованы дополнительные количества ТГ матери, что приведет к повышению потребности в них и дополнительной стимуляции ЩЖ.

В популяции с недостаточным потреблением йода около трети беременных имеют уровень тироксина на нижней границе нормы и ниже. Интересно, что у $2 / 3$ этих женщин этот показа- 
тель во время беременности так и остается крайне низким. A, напротив, у большинства женщин с повышенными значениями йода в I триместре высокая концентрация гормона сохраняется и впоследствии. Подобные наблюдения показывают необходимость контроля ТГГ в ранние сроки беременности, что позволит вовремя провести коррекцию и предупредить функциональные нарушения ЩЖ в дальнейшем.

Беременность рассматривается как состояние, потенцирующее влияние йода на организм как матери, так и плода, и одновременно является фактором формирования йодного «обкрадывания». Дефицит йода приводит к нарушению синтеза ТГ и развитию так называемых «йоддефицитных заболеваний».

Снижение потребления йода в период гестации приводит к хронической стимуляции ЩЖ, относительной гипотироксинемии и формированию зоба как у матери, так и у плода. Под относительной гестационной гипотироксинемией подразумевают состояние, при котором уровень свободного тироксина у беременной не достигает должного для этого периода жизни, но при этом сохраняется в пределах нормы для здоровых небеременных женщин. Это состояние интерпретируется как признак легкой гипотироксинемии, но может привести к развитию акушерских осложнений, таких как невынашивание беременности, преждевременные роды, врожденные пороки развития у плода, психомоторные нарушения у новорожденных. Такая «бессимптомная» гипотироксинемия у матери является причиной формирования широкого спектра неврологических нарушений плода не только грубого анатомического характера (кретинизм), но и дисфункциональных состояний, в виде аномальной задержки психонейромоторного развития и субклинических нарушений интеллектуального статуса (по типу «субкретинизма»), а также тиреоидной дезадаптации в постнатальном периоде (транзиторный неонатальный эндемический гипотиреоз, диффузный эндемический зоб). 
Здоровая ЩЖ способна адаптироваться к легкому дефициту йода и компенсировать увеличение потребности в ТГ в период гестации.

Недостаточность гормонов ЩЖ замедляет процессы миелинизации, синаптогенеза и дифференцировки клеток в головном мозге плода. У детей, рожденных от матерей с дефицитом йода во время беременности, имеется риск когнитивных нарушений, прежде всего кретинизма. Помимо этого, умеренный и тяжелый ЙД у детей может приводить к отставанию в физическом развитии. Таким образом, к группе риска развития ЙДЗ относятся дети первых лет жизни, женщины в период беременности и лактации, а также жители эндемичных регионов, к которым принадлежит почти $95 \%$ территории России.

\section{Способы лабораторной диагностики}

В эпидемиологических исследованиях нормальный показатель йодурии составляет более 100 мкг/л (WHO, 2013). Медиана йодурии может быть использована для оценки потребления йода в популяции, однако определение йода в суточной моче не может использоваться для оценки потребления йода отдельными пациентами. Избыточным уровнем является медиана йодурии более 300 мкг/л для общей популяции и 500 мкг/л для беременных женщин. Американская тиреоидологическая ассоциация предлагает считать избыточным уровнем йодурию на уровне более 500 мкг/л, что соответствует суточному поступлению 1100 мкг (ATA Statement, 2013).

Альтернативным биомаркером обеспеченности йодом рассматривается уровень тиреоглобулина (Tg). Показатель содержания $\mathrm{Tg}$ не более 13 мкг/л ассоциируется с адекватной обеспеченностью йодом. Уровень $\mathrm{Tg}<13$ соответствует медиане йодурии $\geq 100$ мкг/л (для беременных $\geq 150$ мкг/л). 
Предложено использовать в качестве маркера обеспеченности йодом определение его содержания в волосах. Ниже приведены референсные значения содержания йода (мкг/г) в волосах:

- дефицит < 0,2 мкг/г;

- пониженная обеспеченность (преддефицит) - 0,2-0,5 мкг/г;

- оптимальная обеспеченность - 0,5-0,8 мкг/г;

- повышенная обеспеченность (предизбыток) - 0,8-1,2 мкг/г;

- избыток > 1,2 мкг/г.

\section{Варианты коррекции}

В большинстве препаратов йод присутствует в соединении с калием в виде калия йодида. Это соединение входит в состав многих лекарственных средств (табл. 14).

Т а бли ца 14

Лекарственные средства, содержащий йод

\begin{tabular}{|c|c|c|}
\hline Препарат & Производитель & $\begin{array}{c}\text { Форма выпуска, } \\
\text { дозировка, мкг }\end{array}$ \\
\hline «Йодомарин» & «Берлин-Хеми», Германия & Таблетки $-100,200$ \\
\hline «Йодбаланс» & «Мерк», Германия & Таблетки $-100,200$ \\
\hline «Йод Витрум» & «Юнифарм», США & Таблетки $-100,200$ \\
\hline Калия йодид & «Оболенское», Россия & Таблетки $-100,200$ \\
\hline «Микройодид» & «Татхимфарм», Россия & Таблетки $-100,200$ \\
\hline
\end{tabular}

Данные препараты используют для профилактики и устранения гипотиреоза, связанного с йодной недостаточностью. Показаны они и беременным для предотвращения осложнений дефицита йода. Но при их употреблении нельзя превышать суточную дозу 200 мкг. При этом следует учитывать, что далеко не каждый гипотиреоз спровоцирован ЙД. Снижение продукции ТГ может быть следствием врожденных аномалий, воспалительных процессов в ЩЖ. Еще одна причина - поражения гипофиза и гипоталамуса. При патологии гипоталамо-гипофизарной системы 
даже на фоне нормального содержания йода продукция ТГ будет нарушена. Назначение йодсодержащих средств при таких состояниях будет бесполезным.

Еще один йодсодержащий препарат - «Йод-Актив». Здесь йод включен в структуру молочного белка казеина. «Йод-Актив» это биологически активная добавка. Кроме того, йод включен в состав таких комплексных витаминно-минеральных средств, как «Витрум», «Центрум», «Витамакс».

Йод также входит в ряд лекарственных средств, которые используются как антсептики (йодная настойка или спиртовый раствор калия йодида, йодонат, йодопирон, бетадин, раствор Люголя). Некоторые препараты йода («Йоксилан», «Йоверсол», «Йодиксанол», и др.) используют в рентгенологии в качестве контрастных веществ для диагностики состояния сосудов, органов ЖКТ и мочевыводящей системы.

Использование йодированной пищевой соли (пищевая соль, обогащенная йодатом калия) имеет огромное профилактическое значение и может компенсировать до $90 \%$ дефицита данного микроэлемента в рационе россиян.

Взаимодействие с другими препаратами. Медь, цинк, железо, селен, улучшают усваивание йода, и усиливают его эффекты. Йод и витамины А, E, C, D, B9 взаимно усиливают действие друг друга. Поэтому при их низком содержании отмечаются признаки йододефицита.

Антагонистами йода являются: марганец, кобальт, свинец, а также галогены (фтор, хлор, бром). Антибиотики, сульфаниламиды, жаропонижающие средства, антиаритмический препарат «Кордарон» тоже уменьшают эффективность йода. 


\section{цинк}

Цинк (лат. - Zincum, Zn) - один из жизненно важных микроэлементов в нашем организме.

Еще наши далекие предки сталкивались с этим металлом. Ведь латунь, сплав меди и цинка, научились изготавливать еще в античности. Соединения Zn использовали в качестве средств по уходу за кожей. Однако долгое время не удавалось получить чистый цинк из руды. Эти трудности были обусловлены особенностями данного металла. В руде он присутствует в виде окиси, ZnO. Восстановление окиси до металлического цинка происходит при нагревании до высокой температуры. Эта температура выше, чем температура его кипения. В результате процесс восстановления сопровождается образованием паров Zn. При контакте с кислородом воздуха газообразный цинк воспламеняется, в результате чего вновь образуется $\mathrm{ZnO}$. Умельцы Древнего Китая и Индии нашли выход и научились производить металл в глиняных сосудах без доступа кислорода. В Европе металлический $\mathrm{Zn}$ появился лишь в средневековье. Великий ученый того времени Парацельс упоминал о нем в своих трудах. Само происхождение названия доподлинно неизвестно. Предполагают, что оно связано с немецким Zincen, Zincum, что переводится как «зубец»- металлические кристаллы своей формой напоминают иглы. В XVIII в. в Англии, а затем в Германии начато промышленное производство цинка.

В таблице элементов Менделеева Zn располагается в побочной подгруппе II группы 4-го периода. Его порядковый номер 30 указывает на то, что вокруг атомного ядра вращаются 30 электронов, два из которых неспарены. Поэтому цинк двухвалентен, Zn (II). Его атомная масса - 65,38. Плотность 7,133 г/см ${ }^{3}$ Он представляет собой среднепрочный металл с синевато-белым окрасом. В сравнении со многими другими ме- 
таллами он легкоплавкий и летучий. Его температура плавления составляет $419,6^{\circ} \mathrm{C}$, а температура кипения - 906,2 ${ }^{\circ} \mathrm{C}$. Металл довольно пластичен, хорошо поддается ковке, его можно скатывать в фольгу. При контакте с атмосферным кислородом на поверхности цинка образуется тончайшая оксидная пленка, которая предохраняет его от дальнейшего окисления. Однако металл быстро разрушается при взаимодействии с углекислым и сернистым газами. При взаимодействии с галогенами в присутствии влаги он воспламеняется с образованием соединений-галогенидов. Также он воспламеняется при нагревании на воздухе с образованием ZnO. При этом его пламя имеет зелено-голубой цвет. Некоторые соединения взрывоопасны или испускают свечение. По распространенности в земной коре цинк занимает 23-е место среди других элементов периодической системы. Здесь его содержание составляет $8,3 \cdot 10^{-3} \%$. Zn включен в состав более 60 минералов. В чистом виде в естественных условиях встречается крайне редко.

Цинк является незаменимым микроэлементом для всех форм жизни, при этом для поддержания нормальной физиологии человеческого организма он имеет решающее значение. Организм человека содержит в среднем 2-3 г цинка, при этом почти 90 \% его сосредоточено в мышечной и костной тканях, а также ткани печени и поджелудочной железе.

\section{Основы метаболизма}

Гомеостатическая регуляция метаболизма цинка осуществляется за счет увеличения абсорбции во время дефицита и выведения во время восполнения запасов цинка. Всасывание и выведение Zn в ЖКТ являются основными механизмами поддержания гомеостаза цинка. Всасывание цинка происходит в тонком кишечнике, причем наибольшая скорость всасывания наблюдается в тощей кишке, но двенадцатиперстная кишка способствует максимальному всасыванию $\mathrm{Zn}$ из-за воздействия на нее более высо- 
кой концентрации цинка после еды. После этого избыток эндогенного цинка может секретироваться в кишечник и выводиться с калом. Во время ограниченного потребления $\mathrm{Zn}$ с пищей его экскреция с фекалиями падает с одновременным увеличением кишечной абсорбции, таким образом, сохраняется постоянная концентрация цинка в тканях / плазме. С другой стороны, при избытке $\mathrm{Zn}$ фекальная экскреция цинка увеличивается, а абсорбция не нарушается.

Транспорт $\mathrm{Zn}$ из энтероцитов осуществляется посредством двух разнонаправленно действующих его переносчиков ZIP-белков (увеличивают уровни цитозольного цинка) и ZnTбелков (снижают уровни цитозольного цинка). Белки ZIP транспортируют цинк из внеклеточного пространства и внутриклеточных органелл в цитоплазму, тогда как белки ZnT действуют как экспортеры внутриклеточного цинка. Цинк, абсорбируемый энтероцитами, либо сохраняется в виде металлотионеина, либо транспортируется через базолатеральную мембрану посредством ZnT. Металлотионеины представляют собой низкомолекулярные, богатые цистеином цинксвязывающие внутриклеточные протеины, специфически экспрессируемые в тканях организма человека. Они имеют ряд сложных клеточных функций, включая экспрессию генов, пролиферацию и дифференцировку, регулирование внутриклеточного гомеостаза цинка и уменьшение окислительного стресса.

Важным компонентом системы гомеостаза Zn в организме человека является поджелудочная железа. Ацинарные клетки поджелудочной железы обладают гораздо более высокими концентрациями $\mathrm{Zn}$ по сравнению с островковой тканью. Подсчитано, что при нормальных диетических условиях 1-2 мг/сут Zn поступает в пищеварительный тракт из экзокринной части поджелудочной железы.

Потеря Zn через ЖКТ составляет примерно половину всего $\mathrm{Zn}$, выводимого из организма. Значительное количество цинка секретируется с желчью и кишечником, но большая его часть 
реабсорбируется. Это важный процесс в регулировании баланса $\mathrm{Zn}$. Другие пути выведения цинка включают мочу и поверхностные потери (шелушение кожи, волос, пота).

\section{Физиологические функции}

Являясь двухвалентным катионом и переходным металлом, $\mathrm{Zn}$ принимает активное участие в широком спектре каталитических и регуляторных реакций. Он проявляет себя как критически значимый компонент большого числа ферментов, участвующих в синтезе фолиевой кислоты, репликации нуклеиновых кислот. $\mathrm{Zn}$ выполняет важнейшие функции, входя в состав специфических белков - металлопротеинов, обеспечивая их структурную поддержку, а также служит ферментативным кофактором.

Основные физиологические эффекты Zn:

- участие в функции более 300 ферментов и 1000 факторов транскрипции (белков, контролирующих скорость передачи генетической информации от РНК к ДНК; цитоплазматических ферментов, например супероксиддисмутазы и фосфодиэстеразы; митохондриальных ферментов, например цитохромоксидазы и пируваткарбоксилаыа; ядерных ферментов, например ДНК и РНК-полимераз, ферментов аппарата Гольджи, например пептидаз и маннозидаз);

- регуляция экспрессии генов;

- участие в регуляции апоптоза клеток;

- стабилизация клеточных мембран, включая антиоксидантные механизмы;

- участие в синтезе, хранении и высвобождении инсулина;

- модуляция возбудимости нейронов;

- структурная роль в так называемых «цинковых пальцах» - небольших молекулах белка, имеющих множество своеобразных выступов и обеспечивающих тандемные контакты с их молекулой-мишенью и, следовательно, ее стабилизацию;

- регулирование внутриклеточных сигнальных путей в клетках врожденного и адаптивного иммунитета; 
- влияние на морфологическую и физиологическую целостность тимуса (кофактор в образовании активного тимулина, выделяемого клетками тимуса);

- контроль активности натуральных киллеров и цитотоксических моноцитов;

- регуляция сна (взаимодействие с глутаматергическими рецепторами головного мозга).

\section{Содержание в продуктах, суточные нормативы потребления}

Цинк широко распространен в целом ряде доступных пищевых продуктов, при этом мясо, рыба, моллюски и птица являются основными источниками биодоступного Zn. Самое большее количество цинка на порцию (74 мг) в сравнении с другими продуктами питания содержат устрицы, однако у современного человека большую часть этого микроэлемента в рационе обеспечивают красное мясо и птица. Другие полезные источники пищи включают бобы, орехи, определенные виды морепродуктов (например крабов и омаров), цельнозерновые, обогащенные хлопья для завтрака и молочные продукты.

Известно, что основным фактором, способствующим дефициту $\mathrm{Zn}$, является высокое потребление фитатсодержащего белка зерновых в развивающихся странах, и в связи с этим, согласно современным данным, выяснено, что почти 2 млрд человек могут испытывать дефицит данного микроэлемента. Фитаты, которые содержатся в цельнозерновом хлебе, крупах, бобовых и других продуктах питания, связывают цинк и препятствуют его усвоению. Таким образом, биодоступность $\mathrm{Zn}$ из зерновых и растительных продуктов ниже, чем из продуктов животного происхождения, хотя многие продукты на основе зерна и растений попрежнему являются хорошими источниками Zn.

Избранные пищевые источники цинка представлены в табл. 15. 


\section{Содержание цинка в продуктах питания}

\begin{tabular}{|l|c|}
\hline \multicolumn{1}{|c|}{ Продукт } & Содержание, мг/100 г \\
\hline Устрицы & 60 \\
\hline Ростки пшеницы & 30 \\
\hline Семечки тыквенные & 10 \\
\hline Говядина & 8,4 \\
\hline Отруби пшеничные & 7,27 \\
\hline Кунжут & 7 \\
\hline Какао порошок & 6,81 \\
\hline Орех кедровый & 6,45 \\
\hline Баранина & 6 \\
\hline Семена подсолнечника & 5,3 \\
\hline Чечевица & 4,8 \\
\hline Сыр твердый & 4 \\
\hline Арахис & 4 \\
\hline Печень говяжья & 4 \\
\hline Овес & 3,97 \\
\hline Курица & 3,5 \\
\hline Свинина & 3,5 \\
\hline Пшеница & 3,46 \\
\hline Молоко сухое & 3,42 \\
\hline Фасоль (зерно) & 3,21 \\
\hline
\end{tabular}

Рекомендуемые диетические нормы потребления Zn в зависимости от возраста и пола представлены в табл. 16.

Таблица 16

\section{Рекомендуемые диетические нормы для цинка, мг}

\begin{tabular}{|l|c|c|c|c|}
\hline \multicolumn{1}{|c|}{ Возраст } & Мужской пол & Женский пол & Беременность & Лактация \\
\hline $0-6$ месяцев & 2 & 2 & - & - \\
\hline $7-12$ месяцев & 3 & 3 & - & - \\
\hline $1-3$ года & 3 & 3 & - & - \\
\hline $4-8$ лет & 5 & 5 & - & - \\
\hline $9-13$ лет & 8 & 8 & - & - \\
\hline $14-18$ лет & 11 & 9 & - & - \\
\hline $19-50$ лет & 11 & 8 & $11-12$ & 12 \\
\hline
\end{tabular}


FDAc 1 января 2020 г. обязало производителей пищевых продуктов использовать новый вариант маркировки этикетки (Nutrition Facts и Supplement Facts) с указанием содержания цинка в том или ином продукте. Следует отметить, что продукты, обеспечивающие $20 \%$ или более дневной нормы того или иного витамина или микроэлемента, считаются богатыми источниками питательных веществ, при этом продукты, обеспечивающие более низкий процент дневной нормы, также способствуют здоровому питанию (U.S. Foodand Drug Administration).

\section{Эпидемиология потребления}

Согласно мнению экспертов ВОЗ, в настоящее время субоптимальное цинковое питание характерно почти для половины населения мира, при этом дефицит Zn является 11-м по величине фактором риска смертности и заболеваемости при различных патологических состояниях в целом (ВО3). Анализ исследований, изучающих особенности биодоступности $\mathrm{Zn}$, физиологических потребностей и прогнозируемой абсорбции этого микроэлемента у человека, позволяет предположить, что распространенность цинкового дефицита варьируется от 4 \% (в европейских странах, включая Великобританию, Швецию, Германию и Францию) до 73 \% в Бангладеш, Индии и Непале. Более поздняя оценка, основанная на аналогичных оценках, также предсказывала неадекватное потребление $\mathrm{Zn}$ более чем у $25 \%$ населения ЮгоВосточной Азии и Африки. В соответствии с данными обстоятельствами группа экспертов ВОЗ сделала приоритетной задачу минимизации дефицита $\mathrm{Zn}$ в развивающихся странах в рамках Цели 1 тысячелетия в области развития: искоренение крайней нищеты и голода.

Возникновение дефицита Zn обычно связано с его недостаточным потреблением или абсорбцией цинка, повышенными потерями из организма или повышенными потребностями орга- 
низма в данном микроэлементе. В определенных ситуациях некоторые группы людей становятся более подверженными риску дефицита или недостаточности $\mathrm{Zn}$.

Группы риска по возникновению нарушений цинкового статуса:

1. Люди с патологией ЖКТ и другими патологическими состояниями. Оперативное лечение органов ЖКТ и расстройства пищеварения (такие как язвенный колит, болезнь Крона и синдром короткой кишки) могут снизить всасывание $\mathrm{Zn}$ и увеличить эндогенные потери $\mathrm{Zn}$, прежде всего из ЖКТ и, в меньшей степени, из почек.

2. Вегетарианцы. Биодоступность Zn при вегетарианских диетах ниже, чем при невегетарианских диетах, потому что вегетарианцы не едят мясо, которое с высоким содержанием биодоступного цинка может усилить его усвоение. Кроме того, вегетарианцы обычно едят много бобовых и цельнозерновых, которые содержат фитаты, связывающие Zn и препятствующие его усвоению. Вегетарианцам иногда требуется на $50 \%$ больше дневной нормы Zn, чем невегетарианцам. Кроме того, им может быть полезно использовать определенные методы приготовления пищи, которые уменьшают связывание цинка фитатами и увеличивают его биодоступность. Методы увеличения биодоступности $\mathrm{Zn}$ включают замачивание бобов, зерен и семян в воде на несколько часов перед их приготовлением и выдерживание после замачивания до образования ростков (American Dietetic Association). Вегетарианцы также могут увеличить поступление $\mathrm{Zn}$ в организм, потребляя больше продуктов из дрожжевого теста (например хлеба), чем из пресного теста (например крекеров), потому что закваска частично расщепляет фитаты.

3. Беременные женщины, особенно вступающие в беременность с маргинальным цинковым статусом, подвергаются повышенному риску дефицита Zn отчасти из-за высокой потребности плода в цинке. Лактация также может истощить материнские запасы Zn. 
4. Младенцы в возрасте 7-12 месяцев, находящиеся на исключительно грудном вскармливании. Грудное молоко обеспечивает достаточное количество Zn (2 мг/сут) в течение первых 4-6 месяцев жизни, но не обеспечивает рекомендуемое количество цинка для младенцев в возрасте 7-12 месяцев, которым требуется 3 мг/сут. Помимо грудного молока, младенцы в возрасте 7-12 месяцев должны потреблять соответствующие возрасту продукты или смеси, дополнительно обогащенные Zn.

5. Пациенты с серповидноклеточной анемией. Результаты большого поперечного исследования показывают, что 44 \% детей с серповидноклеточной анемией имеют низкую концентрацию цинка в плазме, возможно, из-за повышенных потребностей в питательных веществах и / или плохого нутритивного статуса. Дефицит Zn также поражает примерно 60-70 \% взрослых с серповидноклеточной анемией.

6. Пациенты, страдающие алкоголизмом. Приблизительно $30-50 \%$ алкоголиков имеют низкий цинковый статус, поскольку потребление этанола снижает всасывание цинка в кишечнике и увеличивает выведение $\mathrm{Zn}$ с мочой. Кроме того, разнообразие и количество пищи, потребляемой многими алкоголиками, ограничено, что приводит к недостаточному потреблению Zn.

\section{Симптомы дефицита и избытка цинка}

Многие из симптомов дефицита $\mathrm{Zn}$ неспецифичны и часто связаны с другими патологическими состояниями организма человека. Дефицит $\mathrm{Zn}$ характеризуется задержкой роста, потерей аппетита и нарушением иммунной функции. В более тяжелых случаях дефицит Zn вызывает выпадение волос, диарею, задержку полового созревания, импотенцию, гипогонадизм у мужчин, а также поражения глаз и кожи

Условный дефицит Zn может наблюдаться у пациентов с синдромом мальабсорбции, хроническими заболеваниями печени и почек, серповидноклеточной анемией и другими патоло- 
гическими состояниями внутренних органов. Другими клиническими состояниями, в патогенезе которых цинковый дефицит может играть значимую роль, являются задержка роста, дисфункция различных видов иммунокомпетентных клеток и когнитивные нарушения.

Симптомами избытка $\mathrm{Zn}$, возникающего вследствие переизбытка его пищевых добавок, являются диарея, головная боль, тошнота, рвота. При длительном пероральном приеме цинка в высоких дозах возникает повышенная продукция металлотионеина в энтероцитах, ответственного за связывание ионов меди. В итоге данная ситуация может закономерно привести к формированию дефицита меди. Люди с низким уровнем меди могут испытывать неврологические проблемы, такие как онемение и слабость в руках и ногах. Национальный институт здоровья (США) считает 40 мг Zn в день максимальной дозой для взрослых и 4 мг Zn в день для младенцев в возрасте до 6 месяцев.

\section{Участие в репродукции}

Известно, что Zn играет ключевую роль в ходе эмбриогенеза, внутриутробного развития плода и секреции молока, что увеличивает нуждаемость в этом микроэлементе в ходе гестации и лактации. Zn-зависимые ферменты, Zn-связывающие факторы и транспортеры цинка необходимы на различных этапах во время репликации ДНК и РНК, распознавания и трансдукции клеточных сигналов, контроля экспрессии генов и регуляция синтеза гормонов. Из приблизительно 100 мг общего Zn, полученного беременными женщинами, 57 \% накапливается у плода, 6,5\% в плаценте, $<1 \%$ в амниотической жидкости, $24 \%$ в матке, $5 \%$ в ткани молочной железы и $6,5 \%$ в расширенный объем материнской крови. Этот дополнительный $\mathrm{Zn}$, полученный при беременности, составляет $\approx 5-7 \%$ от общего количества цинка в организме небеременной женщины. 
Концентрация Zn в плазме или сыворотке крови снижается на 15-35 \% к концу гестации по сравнению с показателями до беременности. Гипоцинкемия в данном случае связана как с физиологической гемодилюцией, являющейся следствием увеличения объема циркулирующей крови, так и с повышенной экскрецией с мочой и активным переносом Zn от матери к плоду, включая поглощение $\mathrm{Zn}$ плацентой и материнскими тканями, такими как костный мозг и печень. Следует отметить, что сродство цинка к сывороточному альбумину ниже у беременных по сравнению с небеременными женщинами, что также ведет к снижению общей концентрации циркулирующего Zn во время беременности.

Известно, что концентрация Zn в эритроцитах увеличивается на 10-15 \% во время беременности. Данное явление связано преимущественно с повышенным синтезом Zn-зависимого фермента карбоангидразы, необходимой для обеспечения метаболизма углекислого газа, вырабатываемого развивающимся плодом. Еще одной причиной возрастания эритоцитарных концентраций цинка является увеличение концентрации белка металлотионеина в ходе гестации на 9-11\%. Увеличение металлотионеина эритроцитов во время беременности может отражать повышенные потребности Zn в клетках, например для защиты материнских эритроцитов от окислительного стресса, связанного с повышенным потреблением кислорода во время беременности.

В ходе изучения особенностей гестационного метаболизма Zn было обнаружено, что плацента обладает некоторой способностью адаптировать скорость поглощения цинка к потребностям плода, например к более быстрым темпам роста при более раннем сроке беременности и при низком статусе $\mathrm{Zn}$ у матери. Трансплацентарная передача Zn происходит в обоих направлениях - от матери к плоду и наоборот, при этом известно, что Zn не проникает через плаценту против градиента концентрации в любом направлении. Детальный механизм транс- 
плацентарного перемещения $\mathrm{Zn}$ в настоящее время до конца неизвестен, но, вероятно, он происходит при активном участии плацентарных транспортеров цинка и металлотионеинов.

\section{Акушерские и перинатальные результаты дефицитарных состояний}

Согласно современной концепции метаболизма макро- и микроэлементов, состояние дефицита $\mathrm{Zn}$ во время беременности у людей может возникать несколькими путями, включая потребление небольших количеств Zn в рационе, использование рационов, содержащих факторы, которые препятствуют усвоению $\mathrm{Zn}$, и разнообразные генетические факторы.

Основным фактором, оказывающим главенствующее влияние на цинковый статус человеческого организма при беременности, является потребление этого микроэлемента с продуктами питания. Алиментарными факторами дефицита цинка среди беременных являются потребление кофе, низкое потребление продуктов животного происхождения и недостаточное разнообразие рациона. Дефицит $\mathrm{Zn}$ в рационе у матери во время беременности снижает темпы роста плода. Другие материнские факторы, такие как возраст пациентки, индекс массы тела, курение и употребление алкоголя во время беременности, влияют не только на клинические исходы беременности, но и на уровень циркулирующего Zn, усугубляя таким образом имевшийся дефицит данного микроэлемента.

Потребление $\mathrm{Zn}$ является одним из решающих факторов для успешного эмбриогенеза. Искусственно созданные модели тяжелой материнской недостаточности цинка у грызунов демонстрировали повышенные показатели потери плода и врожденных пороков развития у выживших плодов, а также снижение темпов роста плода, более низкие показатели имплантации и нарушение роста плаценты. Так была подтверждена гипотеза о том, что $\mathrm{Zn}$ является критически значимым регулятором морфо- 
генеза плаценты и материнской гемодинамики. Так как нарушения формирования и функционирования плаценты играют ведущую роль в формировании таких осложнений гестации, как ПЭ, плацентарная недостаточность, гипоксия плода и синдром ЗРП, вклад дефицита цинка в возникновение и реализацию данных патологических состояний не подвергается сомнению.

Потенциальные перинатальные последствия гравидарного дефицита Zn заключаются прежде всего в патологическом течении ранних сроков беременности. Эмбрионы при хронических цинкдефицитных состояниях у матери характеризуются меньшим количеством митозов, субоптимальными темпами деления клеток и формированием патологической морфологии зародышевых листков. После имплантации цинкдефицитные эмбрионы имеют повышенную скорость гибели клеток в нервной трубке, зрительных пузырьках, почках верхних конечностей, характерную для процессов апоптоза. Также материнский дефицит $\mathrm{Zn}$ может влиять на синтез белка и ДНК и вызывать хромосомное повреждение у эмбриона / плода, которое характеризуется высокой частотой их разрывов и терминальных делеций.

Помимо апоптоза и гибели клеток, при дефиците Zn возникает повышенный окислительный стресс и повреждения, что может способствовать реализации тератогенных эффектов. Zn является компонентом медно-цинковой супероксиддисмутазы, которая превращает супероксидный анион в пероксид водорода и может предотвращать окисление чувствительных к окислительно-восстановительному действию цистеиновых и сульфгидрильных групп в многочисленных белках, включая факторы транскрипции цинковыми пальцами. Zn также способен уменьшать образование свободных радикалов, ингибируя связывание окислительно-восстановительных активных металлов, таких как железо и медь, с мембранами и внутриклеточными участками. В условиях дефицита $\mathrm{Zn}$ клетки и ткани характеризуются накоплением железа частично благодаря повышенной экспрессии белков, участвующих в транспорте, хранении и регуляции $\mathrm{Fe}$. 
Логическим следствием вызванного дефицитом $\mathrm{Zn}$ увеличения окислительного стресса является окислительное повреждение липидов, белков и ДНК, а также увеличение апоптоза, которые могут неблагоприятно влиять на развитие эмбриона, приводя к репродуктивным потерям на разных сроках гестации, а также формированию плацентарной недостаточности.

Адекватное поступление Zn в организм женщины во время беременности может привести к снижению риска ПР. Недоношенные новорожденные подвергаются особому риску развития дефицита $\mathrm{Zn}$ из-за сочетания различных факторов: низкие запасы в организме из-за сокращения времени на передачу $\mathrm{Zn}$ плацентой; увеличение эндогенных потерь; и предельное потребление данного микроэлемента.

Связь между циркулирующим в организме $\mathrm{Zn}$ и массой тела при рождении также не является однозначной. Прослеживается прямая зависимость между рождением маловесных детей и низкими показателями уровня $\mathrm{Zn}$ крови. Так, было выяснено, что сывороточный / плазменный Zn в среднем на 72-333 мкг/л ниже у женщин, родивших ребенка с низкой массой тела, по сравнению с теми, кто родил ребенка с соответствующим весом.

Известно, что в человеческом организме дефицит Zn снижает концентрацию инсулиноподобного фактора роста 1 (ИПФР-1). В норме при активации рецептора ИПФР-1 в клетке происходит каскад фосфорилирования, приводящий к регуляции клеточного цикла и активному делению клеток. Zn необходим для генерации ИПФР-1, фосфорилирования рецептора ИПФР-1 и повышения активности фермента дезокситимидинкиназы, которые участвуют в делении и росте клеток плода. Таким образом, длительно существующие недостаточные концентрации $\mathrm{Zn}$ могут быть дополнительной основой для формирования малого веса новорожденных.

Сегодня доказано существование стойкого неблагоприятного влияния дефицита цинка в гестационном периоде на иммунную систему, АД и функционирование ЦНС. Негативное 
влияние дефицита $\mathrm{Zn}$ на иммунные механизмы может сохраняться в течение нескольких поколений. Дефицит Zn в организме при беременности и в период лактации приводит к снижению выработки оксида азота и почечной дисфункции у потомства, которые сохраняются в зрелом возрасте, что ведет к увеличению риска СC3, таких как артериальная гипертензия. Причины данного состояния заключаются в снижении активности фермента оксида азота синтазы в стенках артериол, а также в почечных нефронах, которые продолжали существовать в зрелом возрасте. Происходящее при этом повышение систолического АД и снижение скорости клубочковой фильтрации, связанное с уменьшением количества и размера нефронов, продемонстрированные у лабораторных животных при цинковом дефиците, дают основание для понимания патогенеза гипертензивных состояний во взрослом состоянии. Цинкдефицитная диета при беременности способствует формированию некоторых поведенческих особенностей потомства, в том числе снижению восприимчивости, дефициту внимания и памяти, что, в свою очередь, связано с низкой экспрессией субъединицы NR1 рецептора NMDA в церебральных тканях плодов.

\section{Способы лабораторной диагностики}

Состояние цинкового обмена трудно адекватно измерить с помощью лабораторных тестов из-за его распределения по организму в качестве компонента различных белков и нуклеиновых кислот. Уровни Zn в плазме или сыворотке являются наиболее часто используемыми показателями для оценки дефицита Zn, но эти уровни не обязательно отражают клеточный статус Zn из-за жестких механизмов гомеостатического контроля. При этом следует помнить, что клинические эффекты дефицита цинка могут присутствовать даже при отсутствии выявления отклонений от нормы его лабораторных показателей. При определении потреб- 
ности в добавках Zn клиницисты учитывают факторы риска (такие как недостаточное потребление калорий, алкоголизм и заболевания пищеварительной системы) и симптомы дефицита $\mathrm{Zn}$ (например нарушение роста у младенцев и детей).

Концентрация Zn в сыворотке крови колеблется на $20 \%$ в течение 24 ч, в основном из-за последствий приема пищи. После еды происходит немедленное начальное повышение, после чего концентрация постепенно снижается в течение следующих 4 ч, а затем повышается до тех пор, пока пища не будет съедена снова. Низкие концентрации $\mathrm{Zn}$ в сыворотке крови могут возникать при нескольких состояниях, представляющих нормальную физиологическую реакцию и не обязательно указывающих на низкий статус цинка. Концентрация $\mathrm{Zn}$ в сыворотке снижается во время острых инфекций и воспалений, что, вероятно, связано с перераспределением Zn из плазмы в печёночную ткань. Стресс и инфаркт миокарда также снижают уровень $\mathrm{Zn}$ в сыворотке. Поскольку Zn транспортируется в плазме в комплексе с альбумином, такие заболевания, как цирроз и белково-энергетическая недостаточность, ассоциированные с гипоальбуминемией, приводят к более низким концентрациям Zn в сыворотке крови. Гемодилюция, наблюдаемая во время беременности, использование комбинированных оральных контрацептивов и других гормональных препаратов также приводят к более низкой концентрации $\mathrm{Zn}$ в сыворотке.

Определение концентрации $\mathrm{Zn}$ в плазме или сыворотке крови в настоящее время является лучшим доступным биомаркером риска дефицита Zn в популяции. Предлагаемые более низкие пороговые значения для концентрации $\mathrm{Zn}$ в сыворотке основаны на данных, собранных во 2-м Национальном обследовании здоровья и питания среди населения США (табл. 17). 
Нижние пороговые значения для оценки концентрации цинка в сыворотке

\begin{tabular}{|l|c|}
\hline \multicolumn{1}{|c|}{ Категория пациентов } & Уровень цинка (мкг/дл) \\
\hline Дети в возрасте до 10 лет & 65 \\
\hline Лица мужского пола старше 10 лет & 70 \\
\hline Лица женского пола старше 10 лет & 66 \\
\hline Беременные женщины в первом триместре беременности & 50 \\
\hline $\begin{array}{l}\text { Беременные женщины во втором-третьем триместре } \\
\text { беременности }\end{array}$ & 56 \\
\hline
\end{tabular}

Риск дефицита Zn считается повышенным и вызывает озабоченность у населения, если низкая концентрация цинка в сыворотке преобладает более чем у 20 \% населения.

\section{Варианты коррекции}

Восполнение дефицита Zn возможно как алиментарным путем, подразумевающим употребление продуктов питания, богатых данным микроэлементом, так и путем использования пищевых добавок.

Биодиступность Zn определяется тремя факторами: цинковым статусом человека, общим содержанием цинка в рационе и доступностью растворимого $\mathrm{Zn}$ из пищевых компонентов диеты. Если цинковый статус человека не учитывается, всасывание $\mathrm{Zn}$ в значительной степени определяется его растворимостью в просвете кишечника, на которую, в свою очередь, влияет химическая форма $\mathrm{Zn}$ и наличие специфических ингибиторов и усилителей всасывания Zn. Также положительное влияние на абсорбцию цинка оказывают белки, поскольку абсорбция $\mathrm{Zn}$ имеет тенденцию увеличиваться с потреблением белка. Высокое содержание животных белков в рационе питания (например говядины, яиц и сыра) улучшает биодоступность $\mathrm{Zn}$ из растительных источников пищи, так как аминокислоты, высвобождаемые из животного белка, способствуют связыванию фитатов. 
Просвещение по вопросам питания, направленное на диверсификацию или изменение рациона, может привести к увеличению потребления продуктов животного происхождения, таких как мясо, молоко, сыр и, следовательно, к увеличению количества биодоступного Zn.

Отдельной стратегией преодоления недостаточности микроэлементного статуса популяции является централизованное обогащение (или фортификация) пищевых продуктов. Примером страны с общенациональной программой обогащения $\mathrm{Zn}$ продуктов питанияявляется Мексика. Помимо цинка, в пшеничную и кукурузную муку, которые используются при приготовлении хлеба и тортильи (двух основных продуктов питания в стране), добавляют другие микроэлементы. Среди нескольких соединений цинка, доступных для обогащения, оксид цинка и $\mathrm{ZnSO}_{4}$ являются наименее дорогими и чаще всего используются в пищевой промышленности. Предлагаемые уровни обогащения муки составляют 30-70 мг цинка на кг. Программы обогащения пищевых продуктов также могут быть специально нацелены на увеличение потребления Zn в группах повышенного риска, таких как младенцы и маленькие дети. Во многих странах в настоящее время детские смеси и продукты для прикорма обогащены $\mathrm{Zn}$ и другими микронутриентами. В соответствии с текущими рекомендациями имеющиеся в продаже стандартные смеси для младенцев содержат цинк в концентрации около 1 мг/л.

Самый простой и доступный способ улучшения цинкового статуса пациента - использование его в виде пищевых добавок. Программы пищевых добавок полезны для использования в наиболее уязвимых подгруппах населения, которые особенно подвержены высокому риску дефицита питательных микроэлементов. Рекомендуемая доза Zn составляет 5 мг/сут для детей от 7 месяцев до 3 лет и 10 мг/сут для детей старшего возраста. Процент элементарного $\mathrm{Zn}$ зависит от формы. Например, примерно 23 \% сульфата цинка состоит из элементарного $\mathrm{Zn}$; таким образом, 220 мг сульфата цинка содержат 50 мг элементарного Zn. 
ВО3 рекомендует использовать водорастворимые соединения сульфата цинка (23\% Zn), ацетата цинка (30 \% Zn) или глюконата цинка $(14 \% \mathrm{Zn})$ в форме сиропов или диспергируемых таблеток для лечения диареи у младенцев (ВО3). Однако сульфат цинка и ацетат цинка имеют сильный металлический, горький и вяжущий вкус, который может ограничивать их широкое применение. Из соединений Zn, разрешенных в Европейском союзе для использования в качестве добавок или для обогащения пищевых продуктов, сульфат цинка (водорастворимый, содержание $\mathrm{Zn} 23$ \%) и оксид цинка (нерастворимый в воде, содержание цинка 80 \%) являются наименее дорогими и наиболее распространенными солям. Цитрат цинка - альтернативное соединение с высоким содержанием Zn (31\%), слабо растворимое в воде, не имеющее неприятного запаха и обладающее относительно низкой стоимостью. Из ограниченных опубликованных данных об абсорбции $\mathrm{Zn}$ из пищевых добавок можно сделать вывод, что глюконат цинка, цитрат цинка и сульфат цинка абсорбируются в одинаковой степени, а оксид цинка абсорбируется немного хуже, таким образом, суммируя вышесказанное, следует отметить, что дефицит Zn может влиять на течение гестации на разных уровнях, реализуя свое действие через различные биохимические механизмы. Согласно целому ряду современных зарубежных исследований различного уровня, дефицит Zn accoциирован с такими серьезными акушерскими осложнениями, как гипертензивные нарушения, маловесность, недоношенность и врожденные аномалии развития новорожденных, а также репродуктивные потери на различных сроках беременности. Ранняя диагностика дефицита $\mathrm{Zn}$ путем измерения концентрации $\mathrm{Zn}$ в сыворотке крови может быть важной для избежания тяжелых пренатальных и постнатальных последствий. Дальнейшие научные исследования в данной области должны быть направлены не только на оценку алиментарного поведения беременных и изучение сывороточного цинкового статуса пациенток, но и на поиск иных биомаркеров, демонстрирующих потенциальные результаты влияния дефицита данного микроэлемента. 


\section{ТЕСТОВЫЕ ЗАДАНИЯ}

1. УСВОЯЕМОСТЬ КАЛЬЦИЯ В КИШЕЧНИКЕ ЗАВИСИТ:

1) от его соотношения с жирами

2) от его соотношения с белками

3) от его соотношения с магнием

4) от его соотношения с фосфором

5) от присутствия инозитфосфорной и щавелевой кислоты

2. ГЛАВНЫМ РЕГУЛЯТОРОМ, ОБЕСПЕЧИВАЮЩИМ ВСАСЫВАНИЕ КАЛЬЦИЯ В ЖЕЛУДОЧНО-КИШЕЧНОМ ТРАКТЕ ЯВЛЯЕТСЯ:
1) кальцитонин
2) паратгормон
3) кальцитриол

3. ОСНОВНЫЕ ПРИЧИНЫ РАЗВИТИЯ ГИПОКАЛЬЦИЕМИИ ВКЛЮЧАЮТ:

1) дефицит витамина $\mathrm{D}$ и его метаболитов

2) дефицит паратгормона

3) избыток продукции паратгормона

4) резистентность рецепторов к паратгормону

5) дефицит альбуминов

4. МЕХАНИЗМ РАЗВИТИЯ ОСТРОЙ ГИПОКАЛЬЦИЕМИИ НЕ ОБУСЛОВЛЕН:

1) связыванием и секвестрацией циркулирующего кальция

2) повышением реабсорбции кальция в почках

3) повышением экскреции кальция с мочой 
5. ДЛЯ ДЕФИЦИТА ВИТАМИНА D НЕ ХАРАКTEPHA

1) гипокальциемия

2) гиперкальциемия

3) гипофосфатемия

4) повышение секреции паратгормона

6. МЕХАНИЗМ РАЗВИТИЯ СУДОРОЖНОГО СИНДРОМА ПРИ ГИПОКАЛЬЦИЕМИИ СВЯЗАН:

1) со снижением общего пула кальция во внеклеточной жидкости

2) со снижением ионизированного кальция внеклеточной жидкости

3) со снижением белковосвязанного кальция внеклеточной жидкости

7. ГИПЕРКАЛЬЦИЕМИЯ МОЖЕТ РАЗВИТЬСЯ В РЕЗУЛЬТАТЕ:

1) тиреотоксикоза

2) первичного гиперпаратиреоза

3) дефицита витамина D

4) гипервитаминоза D

5) почечной недостаточночти

6) интоксикации алюминием

8. РАСТИТЕЛЬНЫЕ ПРОДУКТЫ ЯВЛЯЮТСЯ ЕДИНСТВЕННЫМИ ЗНАЧИМЫМИ ПРИРОДНЫМИ ИСТОЧНИКАМИ В ПИТАНИИ

1) крахмала, некрахмальных полисахаридов, витаминов С, Е, биофлавоноидов

2) белка, НЖК, кальция, железа, селена, витамина $\mathrm{B}_{12}$ 
9. ПРОДУКТЫ ПЕРЕРАБОТКИ ЗЕРНА: МУКА И КРУПЫ ЯВЛЯЮТСЯ ИСТОЧНИКАМИ

1) моно- и дисахаридов, витаминов $\mathrm{B}_{12}, \mathrm{~B}_{2}$, кальция, селена, йода

2) растительного белка, крахмала, витаминов $\mathrm{B}_{1}, \mathrm{~B}_{6}$, PР, фолиевой кислоты, магния

10. БОБОВЫЕ МОГУТ РАССМАТРИВАТЬСЯ В КАЧЕСТВЕ ХОРОШИХ ПИЩЕВЫХ ИСТОЧНИКОВ

1) белка, ПНЖК, токоферолов, фолиевой кислоты, калия, магния

2) крахмала, МНЖК, аскорбиновой кислоты, цинка, кальция

11. ОВОЩИ И ФРУКТЫ ЯВЛЯЮТСЯ ВАЖНЕЙШИМИ ПИЩЕВЫМИ ИСТОЧНИКАМИ НЕЗАМЕНИМЫХ НУТРИЕНТОВ

1) аскорбиновой кислоты, $\beta$-каротина, биофлавоноидов, пищевых волокон

2) аминокислот, витаминов А и Е, кальция

3) аскорбиновой кислоты, кальция, витамина $\mathrm{B}_{2}$, ПНЖК

12. В ПИТАНИИ МОЛОКО И МОЛОЧНЫЕ ПРОДУКТЫ ЯВЛЯЮТСЯ ОСНОВНЫМИ ИСТОЧНИКАМИ

1) кальция, витаминов $B_{2}$ и $A$

2) кальция, железа, натрия, витамина $\mathrm{B}_{1}$

3) магния, аскорбиновой кислоты и биофлавоноидов

4) калия, натрия, МНЖК, витамина Е 
13. МИНЕРАЛЬНЫЙ СОСТАВ МЯСНЫХ ПРОДУКТОВ ХАРАКТЕРИЗУЕТСЯ

1) высоким содержанием кальция, железа, магния, калия

2) высоким содержанием железа, фосфора, цинка, калия

3) низким содержанием кальция, железа, магния, калия

4) низким содержанием железа, фосфора, цинка, калия

14. МОРСКАЯ РЫБА СЛУЖИТ ИСТОЧНИКОМ В ПИТАНИИ

1) НЖК, ПНЖК, йода, кальция, натрия, витаминов E, D

2) ПНЖК семейства омега-6, йода, кальция, витаминов A, D

3) НЖК, йода, калия, витаминов E, D

4) ПНЖК семейства омега-3, йода, фосфора, витаминов A, D

\section{5. ЯЙЦА СЛУЖАТ ИСТОЧНИКАМИ В ПИТАНИИ}

1) полноценного белка, ПНЖК, кальция, витаминов $\mathrm{B}_{1}, \mathrm{E}$

2) полноценного белка, МНЖК, калия, витаминов $\mathrm{B}_{6}, \mathrm{~K}$

3) полноценного белка, лецитина, железа, витаминов $\mathrm{B}_{2}, \mathrm{~A}$

16. ВИТАМИНЫ-АНТИОКСИДАНТЫ

1) A, E, D, биотин

2) A, E, $\beta$-каротин, C, биофлавоноиды

3) $\mathrm{B}_{1}, \mathrm{~B}_{2}, \mathrm{PP}, \mathrm{C}, \mathrm{K}$ 
17. МИКРОНУТРИЕНТЫ - КОФАКТОРЫ (ИЛИ КОФЕРМЕНТЫ) ФЕРМЕНТАТИВНОГО ЗВЕНА АНТИОКСИДАНТНОЙ СИСТЕМЫ

1) цинк, медь, марганец, железо, селен, витамин $\mathrm{B}_{2}$

2) хром, медь, молибден, железо, селен, витамин $\mathrm{B}_{6}$

3) цинк, медь, марганец, никель, хром, витамин РР

18. ВО ВТОРОЙ ПОЛОВИНЕ БЕРЕМЕННОСТИ БОЛЕЕ ЧЕМ В 2 РАЗА УВЕЛИЧИВАЕТСЯ ПОТРЕБНОСТЬ В СЛЕДУЮЩИХ ВИТАМИНАХ И МИНЕРАЛАХ

1) витамины $\mathrm{C}$ и $\mathrm{A}$, калии

2) витамины Е и РР, магнии

3) фолиевой кислоте и витамин $\mathrm{D}$, железе

19. В ПЕРИОД ГРУДНОГО ВСКАРМЛИВАНИЯ НА $50 \%$ И БОЛЕЕ УВЕЛИЧИВАЕТСЯ ПОТРЕБНОСТЬ В СЛЕДУЮЩИХ ВИТАМИНАХ И МИНЕРАЛАХ

1) витаминах C, A, E, D, B 1 , фолиевой кислоте, железе, цинке

2) витаминах $\mathrm{B}_{2}, \mathrm{~B}_{6}, \mathrm{PP}, \mathrm{B}_{12}$, кальции, магнии, йоде

20. МИКРОЭЛЕМЕНТ, НОРМИРУЕМЫЙ В СООТВЕТСТВИИ С ВОЗРАСТНОЙ И ПОЛОВОЙ ДИФФЕРЕНЦИРОВКОЙ
1) кальций
2) селен
3) железо 
ЭТАЛОНЫ ОТВЕТОВ

\begin{tabular}{|c|c|}
\hline Вопросы & Ответы \\
\hline 1 & $1,3,4,5$ \\
\hline 2 & 3 \\
\hline 3 & $1,2,4,5$ \\
\hline 4 & 2 \\
\hline 5 & 2 \\
\hline 6 & 2 \\
\hline 7 & $1,2,4,5,6$ \\
\hline 8 & 2 \\
\hline 9 & 1 \\
\hline 10 & 1 \\
\hline 11 & 1 \\
\hline 12 & 2 \\
\hline 13 & 2 \\
\hline 14 & 3 \\
\hline 15 & 2 \\
\hline 16 & 3 \\
\hline 17 & 2 \\
\hline 18 & 1 \\
\hline 20 & 3 \\
\hline
\end{tabular}




\section{СИТУАЦИОННЫЕ ЗАДАЧИ}

\section{Задача 1}

На прием обратилась больная с жалобами на увеличение щитовидной железы. Живет в местности, где у населения диагностируются заболевания щитовидной железы. Заметила увеличение железы два года назад, размеры не увеличиваются. Объективно: щитовидная железа увеличена при визуальном осмотре, пальпируется равномерно перешеек и доли. Кожа обычная, тремора нет. Пульс 72 в мин, АД 120/70 мм рт ст., внутренние органы без патологии. Глазных симптомов нет.

Вопросы:

1. Сформулируйте диагноз.

2. Составьте план лечебных мероприятий.

3. При потребление какого количества йода может развиться йододефицитный гипотиреоз?

4. Суточная потребность в йоде по рекомендации ВО3?

5. Нормальное значение ТТГ?

\section{Задача 2}

Мальчик, 4,5 месяца. Данные анамнеза: ребенок из двойни от второй беременности. Первая беременность закончилась выкидышем. Роды на 30-й неделе беременности. Масса при рождении 1700 г, длина 36 см. Закричал сразу. Вскармливание искусственное. Прикорма и соков не получал. В весе прибавлял удовлетворительно. Не болел. В последние две недели мать стала отмечать, что ребенок стал вялым, сонливым, наросла бледность кожных покровов, снизился аппетит.

Данные объективного осмотра: состояние средней тяжести. Кожные покровы и конъюнктивы бледные, подкожножировой слой развит удовлетворительно. Дыхание пуэрильное, хрипов нет. Число дыханий 48 в минуту. Тоны сердца умеренно 
приглушены. Частота сердечных сокращений 154 в минуту. Живот мягкий, безболезненный. Печень пальпируется из-под края реберной дуги на 3 см, селезенка - на 1,5 см. Стул регулярный.

Данные проведенного обследования:

Общий анализ крови: эр. $-3,2 \cdot 10^{12} / л$, Нв - 70 г/л, цветовой показатель - 0,65, тромбоциты - 250000 , лейкоциты $5,6 \cdot 10^{9} /$ л, с.я. -32 , лимфоциты - 64, моноциты - 3, эозинофилы - 1 , СОЭ$6 \mathrm{MM} / \mathrm{ч}$.

Вопросы:

1. Какая клиническая форма анемии наиболее вероятна в данном случае?

2. Назовите основные причины анемии у данного ребенка.

3. Какие показатели сывороточного железа наиболее вероятны в данном случае.

4. Лечение?

5. Перечислите заболевания, способствующие развитию анемии у детей грудного возраста.

\section{Задача 3}

Больная М., 41 год, обратилась с жалобами на одышку и сердцебиение при быстрой ходьбе, снижение работоспособности, головные боли и головокружения. Подобные ощущения появились 2-3 месяца назад и постепенно нарастают. Поводом для обращения послужило кратковременное обморочное состояние. Ранее практически не болела. В течение трех лет наблюдается гинекологом по поводу миомы матки небольших размеров. Менструальный цикл не нарушен, месячные через 24 дня, длятся по 6-7 дней, обильные. Имеет двух детей, в анамнезе 6 абортов. При осмотре: достаточного питания, кожа и слизистые бледные, «заеды» в углах рта. Тоны сердца учащены, ритмичные, на верхушке сердца короткий систолический шум. ЧСС 90 в минуту, АД 110/75 мм рт. ст. В легких над всеми полями везикулярное дыхание, хрипов нет. Язык влажный, с небольшим белым налетом по спинке. Живот мягкий, при 
пальпации безболезненный. Печень, селезенка, объемные образования не определяются. В клиническом анализе крови: Нв 89 г/л, эритроциты $-3,1 \cdot 10^{12} /$ л, ЦП - 0,8, СОЭ - 23 мм/ч, лейкоциты: $6,8 \cdot 10^{9} /$ л, Э - $1 \%, \Pi-3 \%, \mathrm{C}-67 \%$, Л $-23 \%, \mathrm{M}-6 \%$, анизоцитоз, пойкилоцитоз.

Вопросы:

1. Сформулируйте диагноз.

2. Назначьте план обследования.

3. Проведите дифференциальную диагностику.

4. Выберите тактику ведения больной.

5. Дайте рекомендации по профилактике. 


\section{ЭТАЛОНЫ ОТВЕТОВ \\ НА СИТУАЦИОННЫЕ ЗАДАЧИ}

\section{Задача 1}

1. Эндемический зоб II ст, эутиреоз.

2. Препараты йода (калия йодид 150 - 200 мкг; тироксин).

3. При потреблении йода менее 10 мкг в сутки.

4. 150-200 мкг.

5. 0,4-4,0 мМЕ/л.

\section{Задача 2}

1. Железодефицитная анемия средней степени тяжести.

Ребенок родился на 30-й неделе беременности с массой тела 1700 г и длиной 36 см. В этом случае при отсутствии профилактики препаратами железа всегда развивается железодефицитная анемия из-за недостаточного депонирования железа во время беременности.

2. Многоплодная беременность, недоношенность, искусственное вскармливание, дефекты вскармливания (соки и прикорм не получал).

3. Низкие показатели сывороточного железа.

4. Терапия препаратами железа.

5. Недоношенность, рахит, гипотрофия.

\section{Задача 3}

1. Миома матки небольших размеров. Гиперполименорея. Железодефицитная анемия средней степени тяжести.

2. Исследование уровня сывороточного железа, ОЖСС и ферритина сыворотки, консультацию гинеколога, УЗИ органов малого таза.

3. В процесс дифференциальной диагностики необходимо исключить возможные источники кровотечений из желудочнокишечного тракта. 
4. Препараты железа внутрь до нормализации показателей красной крови и сывороточного железа.

5. Больной показано наблюдение гинеколога для своевременного решения вопроса об оперативном лечении по поводу миомы матки. 


\section{СПИСОК ЛИТЕРАТУРЫ}

1. Громова О.А., Торшин И.Ю. Магний и «болезни цивилизации»: практическое руководство. - М.: ГЭОТАР-Медиа, 2018.

2. Громова О.А., Торшин И.Ю. Микронутриенты и репродуктивное здоровье: руководство. - М.: ГЭОТАР-Медиа, 2019.

3. Доброхотова Ю.Э., Боровкова Е.И. Питание во время беременности // РМЖ. Мать и дитя. - 2017. - Т. 25, № 15. C. 1102-1106.

4. Маклакова Т.П., Брызгалина С.М. Микроэлементы, макроэлементы и витамины в эндокринологии. - Новокузнецк: Новокузнецкий полиграфический комбинат, 2015.

5. Нормальная беременность: клинические рекомендации Российского общества акушеров-гинекологов. - М., 2019. - 88 с.

6. Нормы физиологических потребностей в энергии и пищевых веществах для различных групп населения Российской Федерации: методические рекомендации / под рук. В.А. Тутельян. - М., 2008.

7. Питание и здоровье населения: мониторинг, анализ, тенденции / С.В. Евстигнеев, В.В. Васильев, В.А. Авроров, Н.Д. Тутов, М.В. Перекусихин. - Старый Оскол, 2018.

8. Питание и нутритивная поддержка во время беременности / Е.И. Кравцова, И.И. Куценко, И.О. Боровиков, С.К. Батмен // РМЖ. Мать и дитя. - 2020. - Т. 3, № 4. - С. 233-241.

9. Ребров В.Г., Громова О.А. Витамины и микроэлементы. - М.: АЛЕВ-В, 2003.

10. Рекомендации Всемирной организации здравоохранения по оказанию дородовой помощи для формирования положительного опыта беременности [Электронный ресурс]. - 2017. 196 c. - URL: https://apps.who.int/iris/bitstream/handle/10665/255150/ 9789244549919 rus.pdf; jsessionid=3C94B215EA83DEA7FC541F97 C9CD61C2?sequence=1 (дата обращения: 10.01.2021). 
11. Роль алиментарных факторов и ожирения у беременных женщин в развитии акушерской и перинатальной патологии / Н.Б. Чабанова, С.И. Матаев, Т.Н. Василькова, Т.П. Шевлюкова, И.А. Трошина // Вопросы питания. - 2017. - Т. 86, № 4. - С. 6-21.

12. Скальный А.В. Микроэлементы. бодрость, здоровье, долголетие. - М.: Эксмо, 2010.

13. American Dietetic Association, Dietitians of Canada. Position of the American Dietetic Association and Dietitians of Canada: vegetarian diets // J. Am. Diet. Assoc. - 2003. - Vol. 103. - P. 748-65.

14. Associations of maternal and neonatal serum trace element concentrations with neonatal birth weight / S. Tsuzuki, N. Morimoto, S. Hosokawa, T. Matsushita // PLoS ONE. - 2013. - Vol. 8. P. e75627. DOI: 10.1371/journal.pone.0075627

15. Burk R.F., Hill K.E. Regulation of selenium metabolism and transport // Annu. Rev. Nutr. - 2015. - Vol. 35. - P. 109-134. DOI: 10.1146/annurev-nutr-071714-034250

16. Butler J.A., Whanger P.D., Tripp M.J. Blood selenium and glutathione peroxidase activity in pregnant women: comparative assays in primates and other animals // Am. J. Clin. Nutr. - 1982. Vol. 36. - P. 15-23. DOI: 10.1093/ajcn/36.1.15

17. Cellular proliferation and vascularization in ovine fetal ovaries: Effects of undernutrition and selenium in maternal diet / A.T. Grazul-Bilska, J.S. Caton, W. Arndt, K. Burchill, C. Thorson, E. Borowczyk, J.J. Bilski, D.A. Redmer, L.P. Reynolds, K.A. Vonnahme // Reproduction. - 2009. - Vol. 137. - P. 699-707. DOI: 10.1530/REP-08-0375

18. Cetin I., Berti C., Calabrese S. Role of micronutrients in the periconceptional period // Hum. Reprod. Update. - 2009. - Vol. 16. P. 80-95. DOI: 10.1093/humupd/dmp025

19. Changes in blood selenium and glutathione concentrations and glutathione peroxidase activity in human pregnancy / B. Zachara, C. Wardak, W. Didkowski, A. Maciag, E. Marchaluk // Gynecol. Obst. Invest. - 1993. - Vol. 35. - P. 12-17. DOI: 10.1159/000292655

20. Characterization of mammalian selenoproteomes / G.V. Kryukov, S. Castellano, S.V. Novoselov, A.V. Lobanov, O. Ze- 
htab, R. Guigó, V.N. Gladyshev // Science. - 2003. - Vol. 300. P. 1439-1443. DOI: 10.1126/science. 1083516

21. Circulating biomarkers of oxidative stress in complicated pregnancies / H. Orhan, L. Önderoglu, A. Yücel, G. Sahin // Arch. Gynecol. Obst. - 2003. - Vol. 267. - P. 189-195.

22. Clinical and Metabolic Response to Selenium Supplementation in Pregnant Women at Risk for Intrauterine Growth Restriction: Randomized, Double-Blind, Placebo-Controlled Trial / E. Mesdaghinia, A. Rahavi, F. Bahmani, N. Sharifi, Z. Asemi // Biol. Trace Elem. Res. 2017. - Vol. 178. - P. 14-21 DOI: 10.1007/s12011-016-0911-0

23. Committee to Review Dietary Reference Intakes for Vitamin D and Calcium, Food and Nutrition Board, Institute of Medicine. Dietary Reference Intakes for Calcium and Vitamin D. - Washington, DC: National Academy Press, 2010.

24. Effect of selenium on markers of risk of pre-eclampsia in UK pregnant women: a randomised, controlled pilot trial / M.P. Rayman, E. Searle, L. Kelly, S. Johnsen, K. Bodman-Smith, S.C. Bath, J. Mao, C.W. Redman // Br. J. Nutr. - 2014. - Vol. 112. - P. 99-111. DOI: $10.1017 / \mathrm{S} 0007114514000531$

25. Effects of maternal micronutrient supplementation on placental function / K. Richard, O. Holland, K. Landers, J.J. Vanderlelie, P. Hofstee, J.S. Cuffe, A.V. Perkins // Placenta. - 2017. - Vol. 54. P. 38-44. DOI: 10.1016/j.placenta.2016.12.022

26. Effects of multivitamin/mineral supplementation on trace element levels in serum and follicular fluid of women undergoing in vitro fertilization (IVF) / M.O. Özkaya, M. Nazıroğlu, C. Barak, M. Berkkanoglu // Biol. Trace Elem. Res. - 2011. - Vol. 139. - P. 1-9. DOI: $10.1007 / \mathrm{s} 12011-010-8637-\mathrm{x}$

27. Evaluation of oxidative stress markers in neonates with intrauterine growth retardation / Z. Hracsko, H. Orvos, Z. Novak, A. Pal, I.S. Varga // Redox Rep. - 2008. - Vol. 13. - P. 11-16. DOI: 10.1179/ $135100008 X 259097$

28. From selenium to selenoproteins: synthesis, identity, and their role in human health / L.V. Papp, J. Lu, A. Holmgren, K.K. Khan- 
na // Antioxid. Redox Signaling. - 2007. - Vol. 9. - P. 775-806. DOI: 10.1089/ars.2007.1528

29. Grabek M., Swies Z., Borzecki A. The influence of selenium on the reproduction of rats // Eur. PMC. - 1991. - Vol. 46. P. 103-105.

30. Hofmeyr G.J., Belizán J.M., von Dadelszen P. Low-dose calcium supplementation for preventing pre-eclampsia: a systematic review and commentary // BJOG. - 2014. - Vol. 121 (8). - P. 951-957. DOI: $10.1111 / 1471-0528.12613$

31. Hunt J.R. Bioavailability of iron, zinc, and other trace minerals from vegetarian diets // Am. J. Clin. Nutr. - 2003. - Vol. 78 (3 Suppl). - P. 633S-9S.

32. In vitro influence of selenium on the proliferation of and steroidogenesis in goat luteinized granulosa cells / X. Yao, M. Ei-Samahy, L. Fan, L. Zheng, Y. Jin, G. Zhang, Z. Liu, F. Wang // Theriogenology. - 2018. - Vol. 114. - P. 70-80. DOI: 10.1016/j.theriogeno$\operatorname{logy} .2018 .03 .014$

33. Institute of Medicine. Dietary reference intakes for calcium and vitamin D. - Washington (DC): The National Academies Press; 2011.

34. Iron and Zinc Homeostasis and Interactions: Does Enteric Zinc Excretion Cross-Talk with Intestinal Iron Absorption? / P. Kondaiah, P.S. Yaduvanshi, P.A. Sharp, R. Pullakhandam // Nutrients. 2019. - Vol. 11 (8). - P. 1885.

35. Karowicz-Bilinska A., Kędziora-Kornatowska K., Bartosz G. Indices of oxidative stress in pregnancy with fetal growth restriction // Free Radical Res. - 2007. - Vol. 41. - P. 870-873. DOI: 10.1080/ 10715760701291647

36. Kasik J., Rice E. Selenoprotein P expression in liver, uterus and placenta during late pregnancy // Placenta. - 1995. - Vol. 16. P. 67-74. DOI: 10.1016/0143-4004 (95) 90082-9

37. King J.C., Shames D.M., Woodhouse L.R. Zinc homeostasis in humans // J. Nutr. - 2000. - Vol. 130. - P. 1360S-1366S. DOI: $10.1093 / \mathrm{jn} / 130.5 .1360 \mathrm{~S}$ 
38. Koçak İ., Aksoy E., Üstün C. Recurrent spontaneous abortion and selenium deficiency // Int. J. Obstet. Gynaecol. - 1999. Vol. 65. - P. 79-80. DOI: 10.1016/S0020-7292 (99) 00022-3

39. Lichten L.A., Cousins R.J. Mammalian zinc transporters: Nutritional and physiologic regulation // Annu. Rev. Nutr. - 2009. Vol. 29. - P. 153-176. DOI: 10.1146/annurev-nutr-033009-083312

40. Mamon M.A.C., Ramos G.B. Maternal selenium-supplementation at various stages of periconception period: influence on murine blastocyst morphology and implantation status // J. Anim. Sci. Technol. - 2017. - Vol. 59. - P. 7. DOI: 10.1186/s40781-017-0132-x

41. Maternal selenium, copper and zinc concentrations in pregnancy associated with small-for-gestational-age infants / H.D. Mistry, L.O. Kurlak, S.D. Young, A.L. Briley, F. Broughton Pipkin, P.N. Baker, L. Poston // Mat. Child Nutr. - 2014. - Vol. 10. - P. 327-334. DOI: 10.1111/j.1740-8709.2012.00430.x

42. Micronutrients in pregnancy: current knowledge and unresolved questions / C. Berti, H. Biesalski, R. Gärtner, A. Lapillonne, K. Pietrzik, L. Poston, C. Redman, B. Koletzko, I. Cetin // Clin. Nutr. - 2011. - Vol. 30. - P. 689-701. DOI: 10.1016/j.clnu.2011.08

43. Prasad AS. Zinc deficiency: its characterization and treatment // Met. Ions. Biol. Syst. - 2004. - Vol. 41. - P. 103-137.

44. Rayman M.P. Selenium. - Springer, New York, NY, USA, 2011. - P. 531-544.

45. Rayman M.P. The importance of selenium to human health // The Lancet. - 2000. - Vol. 356. - P. 233-241. DOI: 10.1016/S01406736 (00) 02490-9

46. Selenium deficiency and miscarriage: A possible link? / J. Barrington, P. Lindsay, D. James, S. Smith, A. Roberts // Int. J. Obstet. Gynaecol. - 1996. - Vol. 103. - P. 130-132. DOI: 10.1111/j.14710528.1996.tb09663.x

47. Selenium dependent glutathione peroxidase activity in human follicular fluid / T. Paszkowski, A. Traub, S. Robinson, D. McMaster // Clin. Chim. Acta. - 1995. - Vol. 236. - P. 173-180. DOI: 10.1016/0009-8981 (95) 98130-9 
48. Selenium status during pregnancy and child psychomotor development - Polish Mother and Child Cohort study / K. Polanska, A. Krol, W. Sobala, J. Gromadzinska, R. Brodzka, G. Calamandrei, F. Chiarotti, W. Wasowicz, W. Hanke // Pediatr. Res. - 2016. Vol. 79. - P. 863. DOI: 10.1038/pr.2016.32

49. Selenium status in UK pregnant women and its relationship with hypertensive conditions of pregnancy / M.P. Rayman, S.C. Bath, J. Westaway, P. Williams, J. Mao, J.J. Vanderlelie, A.V. Perkins, C.W. Redman // Br. J. Nutr. - 2015. - Vol. 113. - P. 249-258. DOI: $10.1017 / \mathrm{S} 000711451400364 \mathrm{X}$

50. Selenium supplementation during in vitro maturation enhances meiosis and developmental capacity of yak oocytes / X. Xiong, D. Lan, J. Li, Y. Lin, M. Li // Anim. Sci. J. - 2018. - Vol. 89. P. 298-306. DOI: 10.1111/asj.12894

51. Selenium supplementation protects trophoblast cells from oxidative stress / M. Watson, L. Van Leer, J. Vanderlelie, A. Perkins // Placenta. - 2012. - Vol. 33. - P. 1012-1019. DOI: 10.1016/j.placenta.2012.09.014

52. Selenoprotein gene nomenclature / V.N. Gladyshev, E.S. Arnér, M.J. Berry, R. Brigelius-Flohé, E.A. Bruford, R.F. Burk, B.A. Carlson, S. Castellano, L. Chavatte, M. Conrad // J. Biol. Chem. 2016. - Vol. 291. - P. 24036-24040. DOI: 10.1074/jbc.M116.756155

53. Severe selenium deficits in pregnant women irrespective of autoimmune thyroid disease in an area with marginal selenium intake / U. Ambroziak, S. Hybsier, U. Shahnazaryan, M. KrasnodębskaKiljańska, E. Rijntjes, Z. Bartoszewicz, T. Bednarczuk, L. Schomburg // J. Trace Elem. Med. Biol. - 2017. - Vol. 44. - P. 186-191. DOI: 10.1016/j.jtemb.2017.08.005

54. The influence of selenium supplementation on postpartum thyroid status in pregnant women with thyroid peroxidase autoantibodies / R. Negro, G. Greco, T. Mangieri, A. Pezzarossa, D. Dazzi, H. Hassan // J. Clin. End. Metab. - 2007. - Vol. 92. - P. 1268. DOI: 10.1210/jc.2006-1821 
55. The possible role of selenium status in adverse pregnancy outcomes / A.B. Mariath, D.P. Bergamaschi, P.H. Rondó, C.A.T. Ana, P. de Fragas Hinnig, J.F. Abbade, S.G. Diniz // Br. J. Nutr. - 2011. Vol. 105. - P. 1418-1428. DOI: 10.1017/S0007114510005866

56. The selenium status of women with a history of recurrent miscarriage / A. Al-Kunani, R. Knight, S. Haswell, J. Thompson, S. Lindow // An. Int. J. Obstet. Gynaecol. - 2001. - Vol. 108. - P. 1094-1097.

57. Vallee B.L., Falchuk K.H. The biochemical basis of zinc physiology // Physiol. Rev. - 1993. - Vol. 73. - P. 79-118. DOI: 10.1152/physrev.1993.73.1.79

58. World Health Organization. - 2009 [Электронный pecypc]. WHO. Recommendations on wheat and maize flour fortification. Meeting Report: Interim Consensus Statement (WHO, FAO, UNICEF, GAIN, MI, FFI). - URL: http://www.who.int/nutrition/publications/ micronutrients/wheat_maize_fort.pdf (дата обращения: 27.09.2020).

59. X-Ray fluorescence imaging and other analyses identify selenium and GPX1 as important in female reproductive function / M.J. Ceko, K. Hummitzsch, N. Hatzirodos, W.M. Bonner, J.B. Aitken, D.L. Russell, M. Lane, R.J. Rodgers, H.H. Harris // Metallomics. 2015. - Vol. 7. - P. 71-82. DOI: 10.1039/C4MT00228H

60. Zinc bioavailability and homeostasis / K.M. Hambidge, L.V. Miller, J.E. Westcott, X. Sheng, N.F. Krebs // Am. J. Clin. Nutr. 2010. - Vol. 91. - P. 1478S-1483S. DOI: 10.3945/ajcn.2010.28674I 
Учебное издание

Олина Анна Александровна, Садыкова Гульнара Камильевна, Прохорова Ольга Валентиновна, Метелева Татьяна Александровна, Ширинкина Елена Викторовна

\title{
МИКРО- И МАКРОЭЛЕМЕНТЫ И ЖЕНСКОЕ ЗДОРОВЬЕ
}

\author{
Учебное пособие
}

Редактор и корректор М.Н. Афанасьева

Подписано в печать 02.07.2021. Формат 60×90/16. Усл. печ. л. 9,0. Тираж 100 экз. Заказ № 113/2021.

ИП Серегина О.Н.

Адрес: 614107, г. Пермь, ул. Металлистов, д. 21, кв. 174. 